\title{
Neolithic Domesticity and other Prehistoric Anomalies: Excavations at Laigh Newton, East Ayrshire
}

\author{
By Ronan Toolis
}

GUARD Archaeology Ltd, 52 Elderpark Workspace, 100 Elderpark Street, Glasgow G51 3TR

With contributions by

Jo Bacon, Torben Bjarke Ballin, Beverley Ballin Smith, Martin Carruthers, Charlotte Francoz, Heather James, Kirsteen McLellan, Gillian McSwan, Susan Ramsay, Ingrid Shearer, Joe Somerville \& Dave Swan 
Published by the Society of Antiquaries of Scotland, www.socantscot.org.uk with Historic Scotland, www.historic-scotland.gov.uk

and the Council for British Archaeology, www.britarch.ac.uk

Editor Helen Bleck

Produced by Archétype Informatique SARL, www.archetype-it.com

ISBN: 9780903903516

ISSN: $1773-3803$

Requests for permission to reproduce material from a $S A I R$ report should be sent to the Director of the Society of Antiquaries of Scotland, as well as to the author, illustrator, photographer or other copyright holder.

Copyright in any of the Scottish Archaeological Internet Reports series rests with the SAIR Consortium and the individual authors.

The maps are reproduced from Ordnance Survey material with the permission of Ordnance Survey on behalf of The Controller of Her Majesty's Stationery Office. (C) Crown copyright 2001. Any unauthorised reproduction infringes Crown copyright and may lead to prosecution or civil proceedings. Historic Scotland Licence No. GD 03032G, 2002.

The consent does not extend to copying for general distribution, advertising or promotional purposes, the creation of new collective works or resale. 


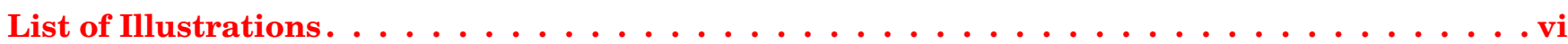

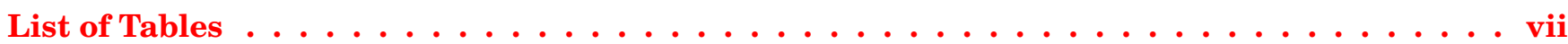

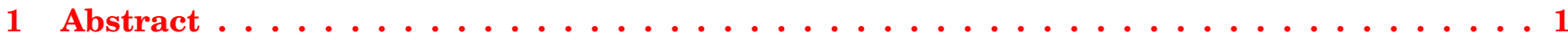

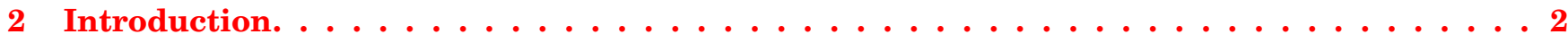

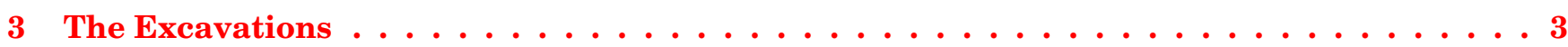

4 Laigh Newton West, by Heather James, Dave Swan \& Joe Somerville . . . . . . . . . . . 4

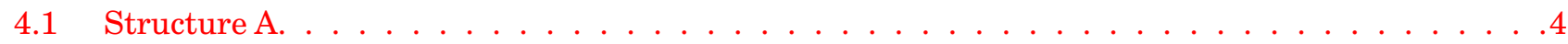

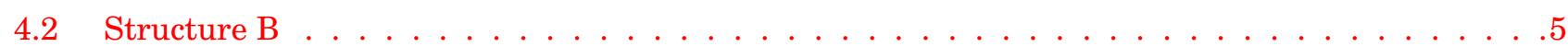

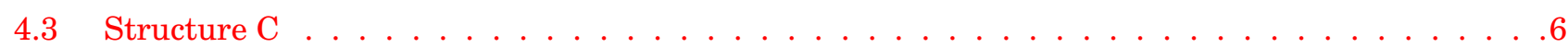

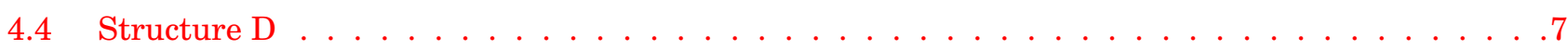

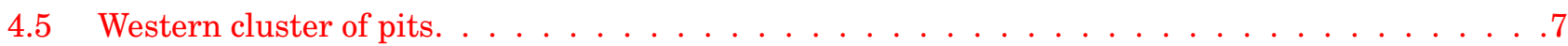

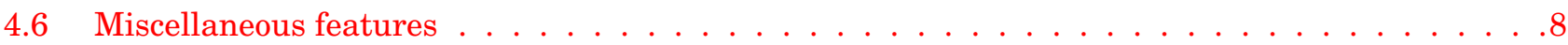

5 Laigh Newton North-west, by Heather James, Charlotte Francoz \& Joe Somerville. . . . . . 12

6 Laigh Newton Central, by Martin Carruthers \& Kirsteen McLellan . . . . . . . . . . . . . . 13

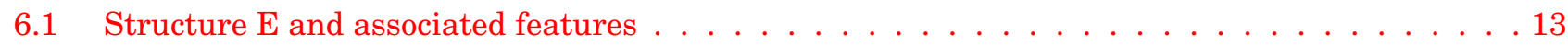

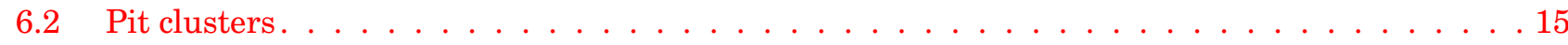

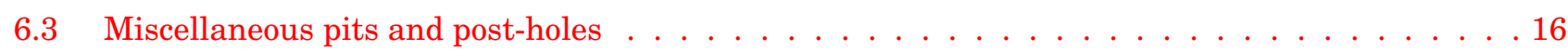

7 Laigh Newton East, by Joe Somerville $\ldots \ldots \ldots \ldots \ldots \ldots$

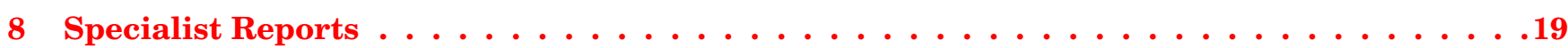

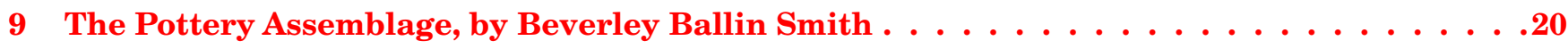

9.1 General observations . . . . . . . . . . . . . . . . . . . . . . 20

9.2 The Laigh Newton West assemblage . . . . . . . . . . . . . . . . . . . . . . . 22

9.3 Laigh Newton North-west. . . . . . . . . . . . . . . . . . . . . . . . . 23

9.4 Laigh Newton Central. . . . . . . . . . . . . . . . . . . . . . . . . . . 23

9.5 Laigh Newton East . . . . . . . . . . . . . . . . . . . . . . . . . 23

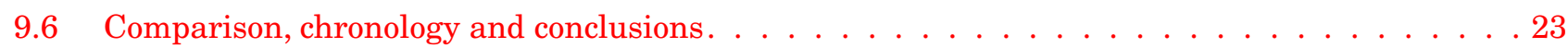

10 The Daub and Other Clay Materials, by Beverley Ballin Smith . . . . . . . . . . . . . . 25 
11 The Lithic Assemblage, by Torben Bjarke Ballin . . . . . . . . . . . . . . . . . 26

11.1 General observations . . . . . . . . . . . . . . . . . . . . . . . 27

11.2 Laigh Newton West . . . . . . . . . . . . . . . . . . . . . . . 27

11.3 Laigh Newton North-west. . . . . . . . . . . . . . . . . . . . . . 28

11.4 Laigh Newton Central. . . . . . . . . . . . . . . . . . . . . . . . . . . . 28

11.5 Laigh Newton East . . . . . . . . . . . . . . . . . . . . . . . . . . 29

11.6 Discussion of the lithic assemblage . . . . . . . . . . . . . . . . . . . . 29

12 Carbonised Plant Remains, by Susan Ramsay ～. . . . . . . . . . . . . . . . . .31

12.1 Laigh Newton West . . . . . . . . . . . . . . . . . . . . . . . . . 31

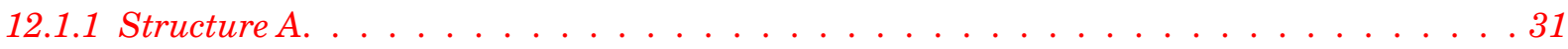

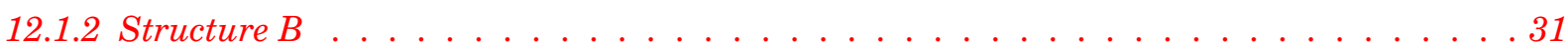

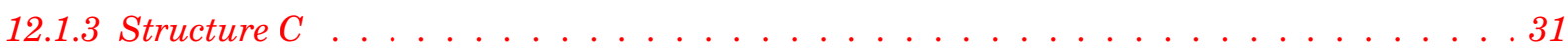

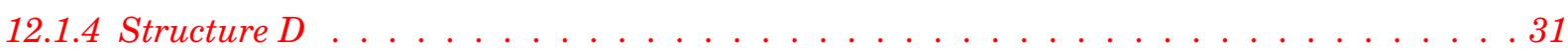

12.1.5 Western cluster of pits . . . . . . . . . . . . . . . . . . . . . . . . . . .

12.1.6 Miscellaneous features . . . . . . . . . . . . . . . . . . . 32

12.2 Laigh Newton Central. . . . . . . . . . . . . . . . . . . . . . . . 32

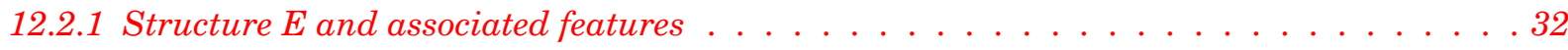

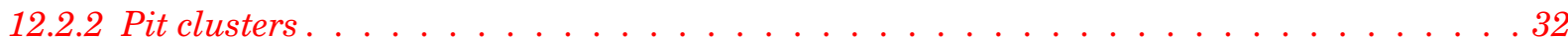

12.2.3 Miscellaneous pits and post-holes. . . . . . . . . . . . . . . . . . . 32

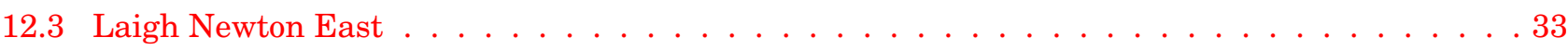

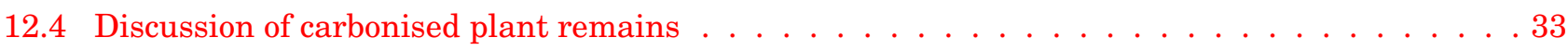

12.4.1 Laigh Newton West . . . . . . . . . . . . . . . . . . . . . . . . . 33

12.4.2 Laigh Newton Central. . . . . . . . . . . . . . . . . . . . . . . . . . . . . . . . 35

12.4.3 Laigh Newton East . . . . . . . . . . . . . . . . . . . . . . . . . . . . . . . . 36

12.4 .4 General observations . . . . . . . . . . . . . . . . . . . . . . . . . . . . . .

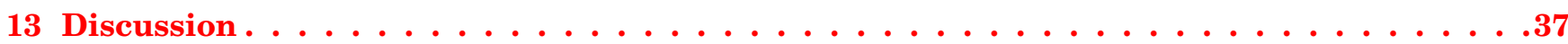

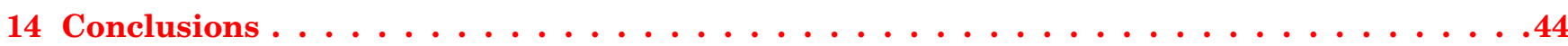

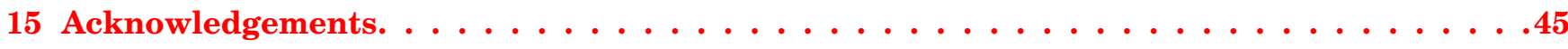

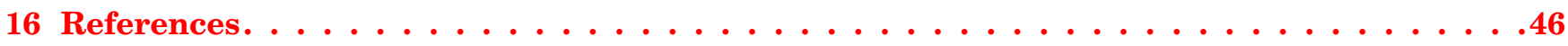

\section{LIST OF APPENDICES}

1 Catalogue of Laigh Newton West Pottery Sherds . . . . . . . . . . . . . . . . .49

2 Catalogue of Laigh Newton North-west Pottery Sherds . . . . . . . . . . . . . .50

3 Catalogue of Laigh Newton Central Pottery Sherds $\ldots \ldots \ldots \ldots \ldots$

4 Catalogue of Laigh Newton East Pottery Sherds $\ldots \ldots \ldots \ldots \ldots$ 
5 Catalogue of Daub Pieces from Laigh Newton $\ldots \ldots \ldots \ldots \ldots$

6 Catalogue of Lithic Assemblages from Laigh Newton $\ldots \ldots \ldots \ldots$

7 Botanical Results from Laigh Newton West - Structure A . . . . . . . . . . . .57

8 Botanical Results from Laigh Newton West - Structure B . . . . . . . . . . . . . .59

9 Botanical Results from Laigh Newton West - Pit 99 and Surrounding Postholes. . . . . . .60

10 Botanical results from Laigh Newton West - Pit 40, Segmented Linear Feature

Possible Roundhouse . . . . . . . . . . . . . . . . . . . . . 61

11 Botanical Results from Laigh Newton West - Western Pits . . . . . . . . . . . . .63

12 Botanical Results from Laigh Newton West - Miscellaneous . . . . . . . . . . . . .64

13 Botanical Results from Laigh Newton East - Rectangular Structure Associated Features . .66

14 Botanical Results from Laigh Newton East - Pit Clusters . . . . . . . . . . . . . . 67

15 Botanical Results from Laigh Newton East - Miscellaneous Pits and Postholes . . . . . . .69

16 Botanical Results from Laigh Newton East - Additional Prehistoric Features . . . . . . . .71 


\section{LIST OF ILLUSTRATIONS}

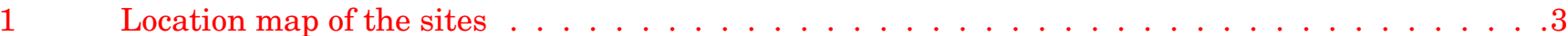

2 Laigh Newton West - feature groups and outline of structures . . . . . . . . . . . . . . .4

$3 \quad$ Aerial view of Laigh Newton West with Loudoun Hill in the background

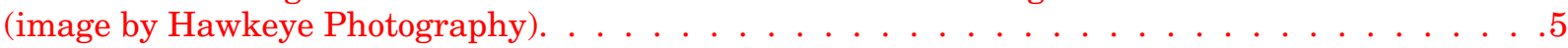

Structure A with details of post-holes. . . . . . . . . . . . . . . . . . . . . . . .6

Structure B with details of pits and post-holes . . . . . . . . . . . . . . . .

Structure $\mathrm{C}$ with details of pits and post-holes. . . . . . . . . . . . . . .

Structure D with details of the central pit . . . . . . . . . . . . . . . . . . .

Western cluster of pits with pit profiles. . . . . . . . . . . . . . . . . . . . . 10

Laigh Newton West -features in the northern part of the site $\ldots \ldots \ldots \ldots$

Laigh Newton Central - feature distribution. . . . . . . . . . . . . . . . . 13

Structure E with feature details . . . . . . . . . . . . . . . . . . . . . . . . . . 14

Western pit clusters with details . . . . . . . . . . . . . . . . . . . . . 15

Laigh Newton East - feature distribution _ . . . . . . . . . . . . . . . . . . . . 17

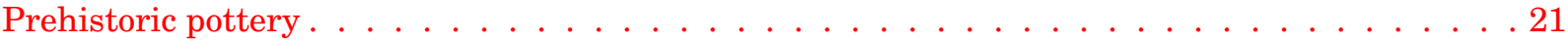

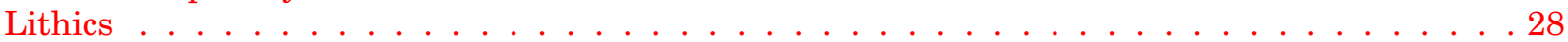

Microblade fragments from Laigh Newton East . . . . . . . . . . . . . . . . . . . . . . . 29

Laigh Newton West - dated features and finds distribution . . . . . . . . . . . . . . . 38

Laigh Newton Central - dated features and finds distribution . . . . . . . . . . . . . . 39 


\section{LIST OF TABLES}

1 Distribution of sherd forms across the excavated areas . . . . . . . . . . . . . . . 20

2 Minimum number of pottery vessels . . . . . . . . . . . . . . . . . . . . 20

$3 \quad$ Lithic artefact list . . . . . . . . . . . . . . . . . . . . 26

4 Dates of the activities at Laigh Newton, as suggested by diagnostic lithic elements . . . . . . . 29

Radiocarbon dates . . . . . . . . . . . . . . . . . . . . . . . . . . . . . . . . . . . 


\section{ABSTRACT}

A series of archaeological evaluations and excavations at Laigh Newton in East Ayrshire revealed evidence for intermittent occupation of this valley terrace between the Mesolithic and the Late Iron Age. The plough-truncated archaeology included the remains of a rectangular building and associ- ated features of the mid-late fourth millennium BC, a more ephemeral structure and related pits of the mid third millennium BC, a charcoal-burning pit of the mid-first millennium $\mathrm{AD}$ and two other rectilinear structures of indeterminate date. 


\section{INTRODUCTION}

Between 2003 and 2007, Glasgow University Archaeological Research Division (GUARD) undertook a series of archaeological evaluations and excavations at Laigh Newton, near Darvel in East Ayrshire. These archaeological works were carried out on behalf of Tarmac Northern Ltd, in advance of the proposed extension to the Loudoun Hill Quarry, which was subject to a planning consent condition imposed by the West of Scotland Archaeology Service in their role as archaeological advisers to East Ayrshire Council.
The first phases of the archaeological works, comprising evaluations in 2003 and a further evaluation and excavation in 2005 had identified two discrete areas of plough-truncated prehistoric and medieval archaeological remains. Excavations of a further two discrete concentrations of prehistoric and medieval remains were carried out in 2007. This report deals solely with the prehistoric evidence encountered, while the medieval archaeological remains are reported elsewhere (James forthcoming). 


\section{THE EXCAVATIONS}

The prehistoric remains at Laigh Newton were located within three discrete concentrations centred at NGR: NS 5937 3684, NS 59823693 and NS 6029 3695 , to the south of the A71 on land belonging to Allanton Farm (illus 1). They lay around 205m OD, on a terrace on the south slope of the Irvine Valley facing Loudoun Hill, within a field previously used as grazing for sheep and cattle. Residual prehistoric artefacts were also recovered from the remains of a medieval farmstead, located downslope of the westernmost site, at NGR: NS 59333693.
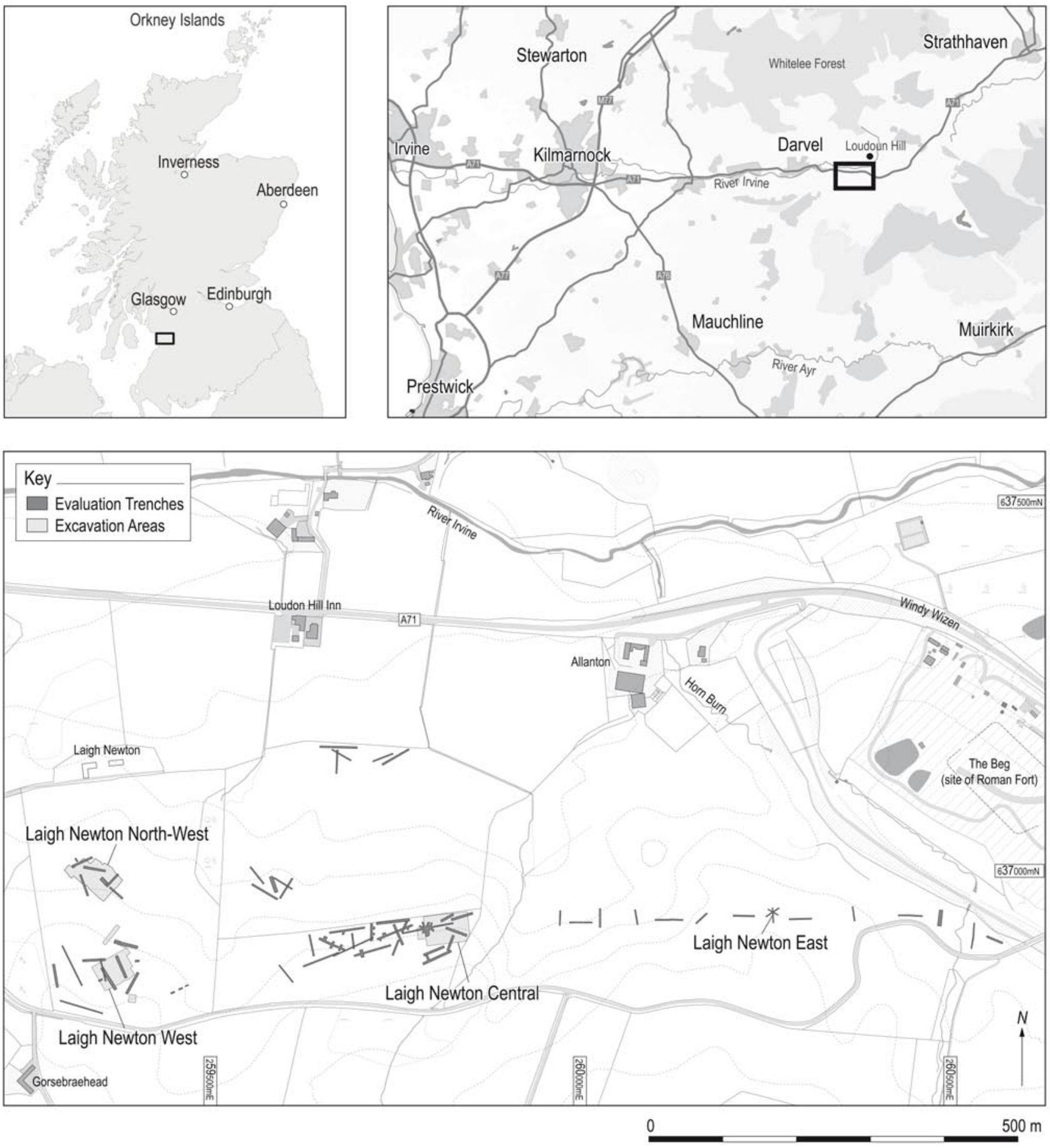


\section{LAIGH NEWTON WEST, by Heather James, Dave Swan \& Joe Somerville}

An excavation area was located where previous evaluation trenches had noted a number of shallow pits and linear features, from one of which a sherd of medieval pottery was recovered (illus 1). Machine excavation of the $0.3-0.5 \mathrm{~m}$ deep topsoil recovered a variety of unstratified finds, including a single fragment of corroded metal, a flint flake, prehistoric pottery sherds and fragments of quartz and chert. Once natural variations and patches of topsoil had been eliminated, numerous archaeological features were visible above the underlying bands of fluvio-glacial and glacial sands and gravels (Context 002). Most of the archaeological features comprised discrete features with no demonstrable stratigraphic relationships to each other. However, as many of the features apparently formed discrete clusters, it was possible to recognise probable spatial relationships between individual features (illus 2).

\subsection{Structure A}

In the south-west corner of the excavation trench (illus 3 and 4), a sub-rectangular arrangement of ten post-holes appeared to form a $15.1 \mathrm{~m}$ long by $6.2 \mathrm{~m}$ wide structure. The south-west side comprised a large, irregularly shaped post-hole (247), interpreted in the field as a possible tree-throw but more likely to owe its irregular form to disturbance caused by the displacement of packing stones by plough action, and three smaller post-holes (246,

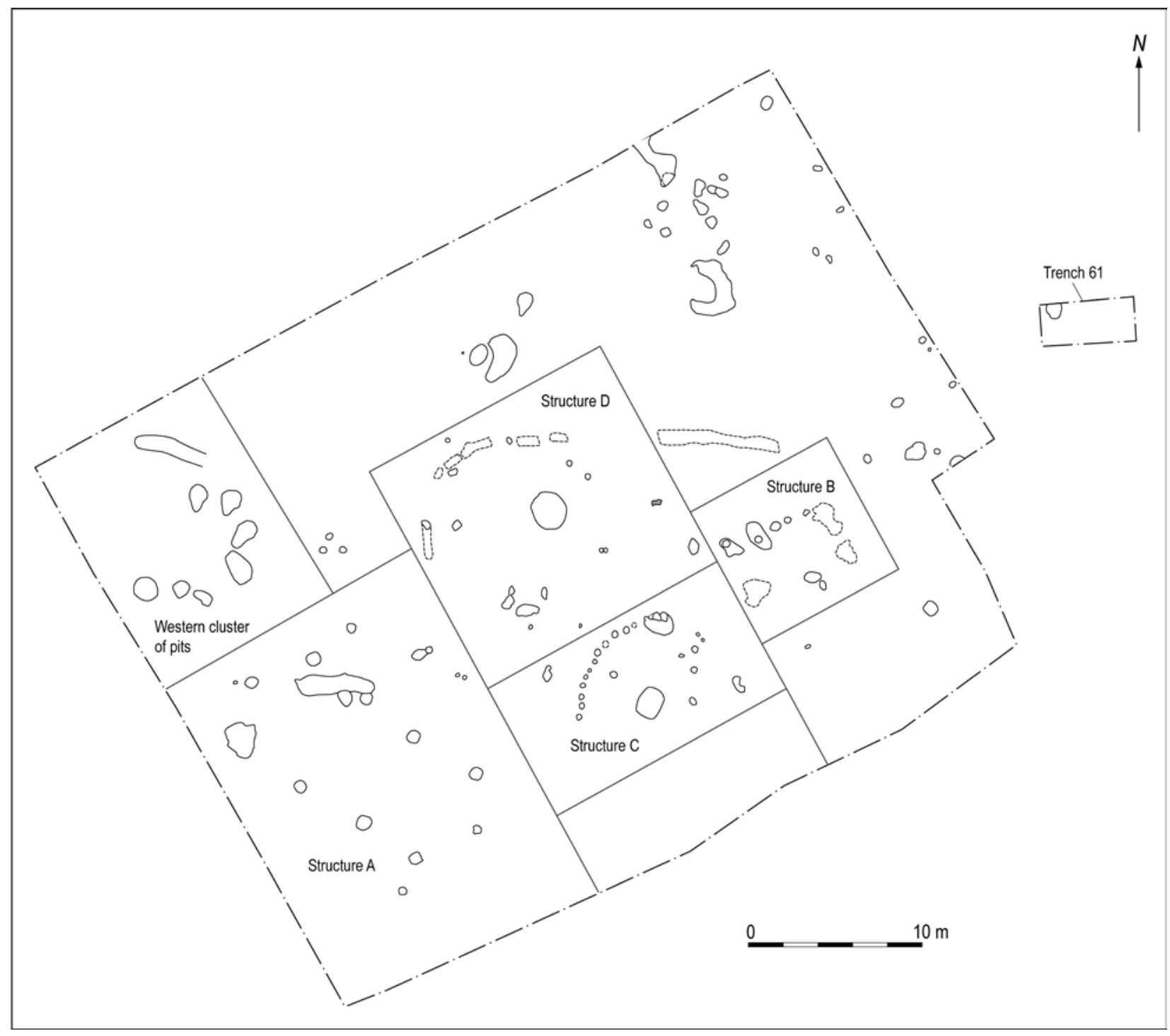

Illus 2 Laigh Newton West-feature groups and outline of structures 


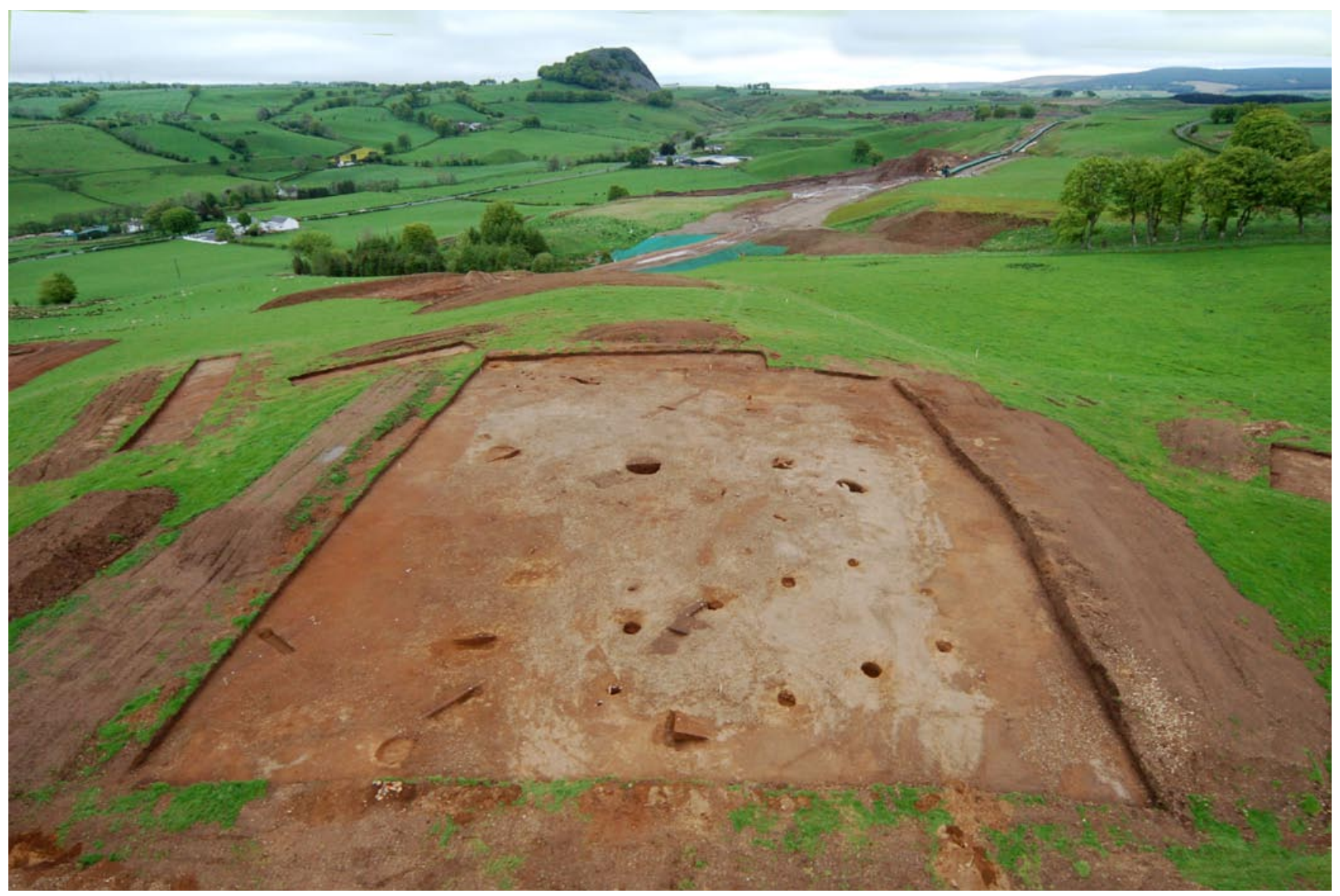

Illus 3 Aerial view of Laigh Newton West with Loudoun Hill in the background (image by Hawkeye Photography)

176 and 135). There were four opposing post-holes on the north-east side (031, 208, 151 and 004). There were also two axial post-holes on the northwest and south-east sides (248 and 130).

Many of the post-holes $(031,151,004,135,176$, 246 and 248) that defined Structure A contained in situ packing stones, though not always apparent in section. A particularly large packing stone was set vertically within the $0.70 \mathrm{~m}$ deep north-west axial post-hole (248). The opposite axial post-hole (130), however, had been truncated to a depth of only $0.12 \mathrm{~m}$ and contained no packing stones. Another post-hole (208) contained a post-pipe but no packing stones.

The only apparent internal features within Structure A were a linear pit (005) and a smaller sub-circular post-hole (154). However, as the linear pit (005) partially cut the fill (209) of one of Structure A's post-holes (208) the linear pit must succeed the abandonment of Structure A. The fill (153) of the linear pit itself was probably cut by the sub-circular post-hole (154), though in section they were too truncated for a relationship to be recorded.

There were a few external features that may be associated with Structure A by virtue of their alignment and proximity to some of the individual features that defined the structure. A stake-hole
(255) lay to the immediate west of the north-west axial post-hole (248). Aligned parallel to the northeast side of the structure, at a distance of $c 2-4 \mathrm{~m}$, were a series of features (post-holes 032, 029, 309,182 and 027) that appeared to align specifically with post-holes along the north-east side of Structure A (031, 208 and 151). On the south-west side, a single post-hole (245) also appeared to align with another of Structure A's post-holes (135).

The finds from Structure A comprised a quartz chip from the fill (164) of post-hole 031, half a hazelnut shell from the basal fill (275) of post-hole 247 and small fragments of burnt bone from the fill (205) of post-hole 032 . Varying amounts of charcoal were also recovered from a number of features (see Ramsay below).

\subsection{Structure $B$}

A second possible rectilinear structure was located towards the south-eastern corner of the excavation area (illus 2 and 5). Structure B included an ENE/WSW aligned line of six post-holes $(052,211$, 050, 049, 048 and 046), two of which (052 and 211) appeared to have been cut through two pits (299 and 051) respectively. A parallel line of post-holes (053, 301, 054, 216 and 047) appeared to form the 


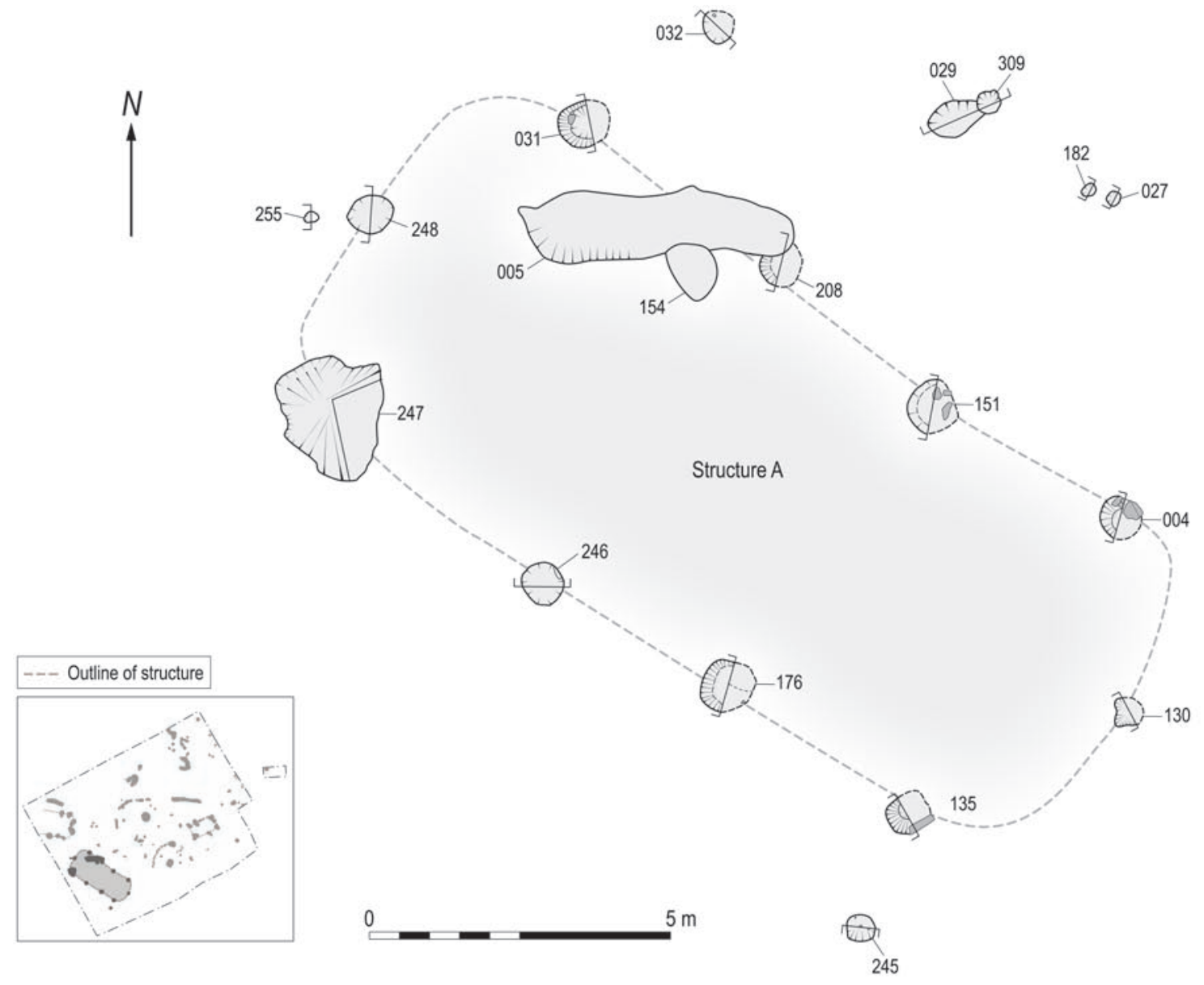

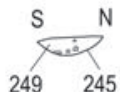
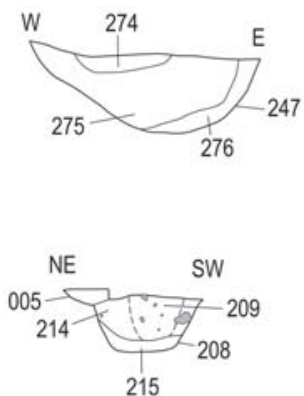
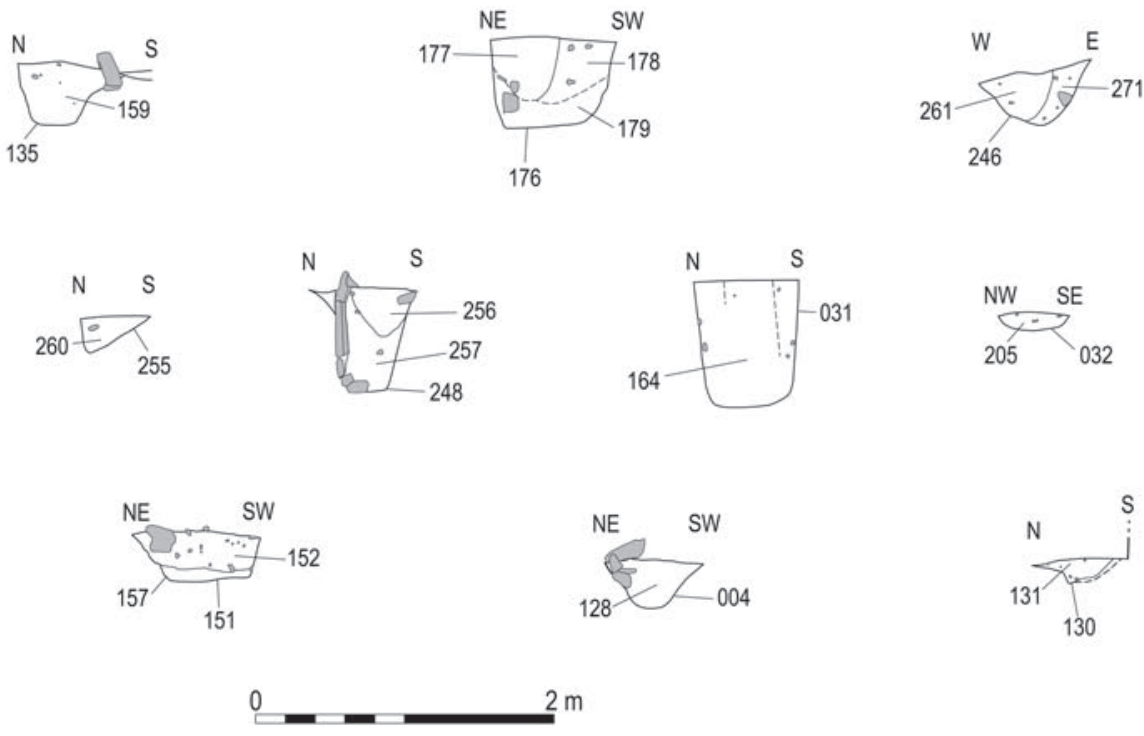

Illus 4 Structure A with details of post-holes

southern matching side of rectangular, timber-built structure measuring $c 6 \mathrm{~m}$ long and $3.5 \mathrm{~m}$ wide. One of the post-holes (047) was heavily truncated by animal burrowing. There were no finds associated with this possible structure, though some of the post-hole fills contained charcoal (see Ramsay below).

\subsection{Structure $C$}

Located between Structures A and B, was a large pit (099) $1.7 \mathrm{~m}$ long, $1.3 \mathrm{~m}$ wide and $0.8 \mathrm{~m}$ deep, and U-shaped in profile with a flat base (illus 2 and 6). It was filled with large angular and rounded stones (100), which appeared to have slumped into the 


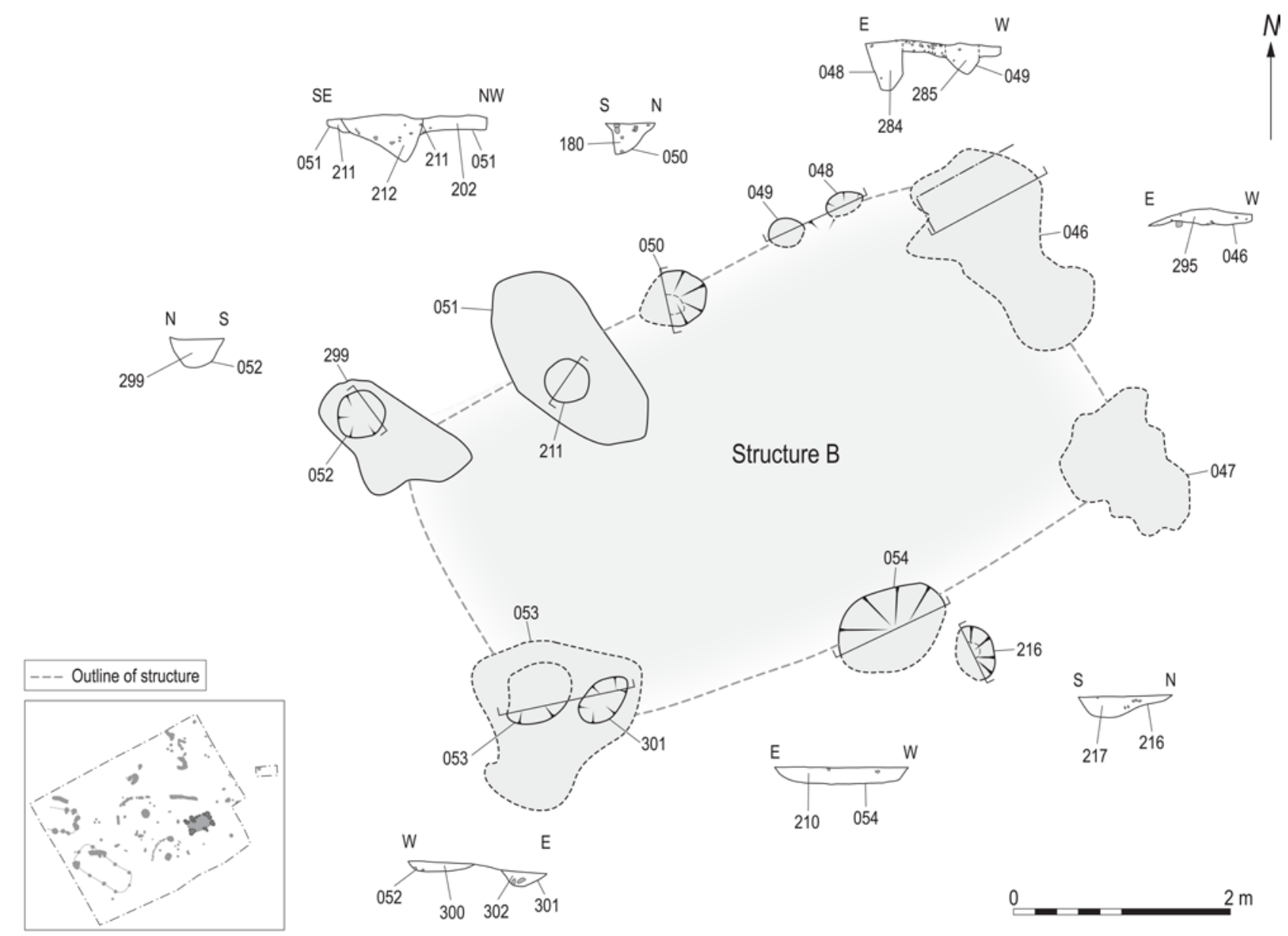

Illus 5 Structure B with details of pits and post-holes

centre. The soil matrix surrounding the stones was loose sandy gravel (024), with flecks of charcoal but no artefacts.

A series of 12 small post/stake-holes (080-087 and 015-018) formed an arc around the pit at a distance of $c 3 \mathrm{~m}$. There were no artefacts retrieved from these features, but the fills of two of the post/stake-holes (086 and 087) contained charcoal flecks. The post/stake-holes forming the arc were generally spaced about $0.3 \mathrm{~m}$ apart. There were several other features to the north $(019,093,094$ and 133) and a further five post-holes $(112,110$, 090-092, 121 and 122) to the east of the pit, which did not appear to form part of any apparent obvious pattern. Two kidney-shaped pits (171 and 239) lay immediately to the west and east of this general cluster of features.

\subsection{Structure $D$}

A large circular pit (040) occupied the centre of the excavation area (illus 2 and 7 ). It had a stepped profile and three fills (116, 115 and 114). The primary deposit (116) contained significant amounts of charcoal and a single flint flake. The secondary fill (115) contained a few charcoal flecks and the final fill (114) again contained significant amounts of charcoal and two flints (see Ballin below).

Curving around the north and west sides of pit 040 was a segmented linear feature $(033,126,037$ and 043), which ran east/west across the excavation area. To the north-west of the excavation area (illus 8), a 5m length of ditch (065) ran on the same east/west alignment. At least one constituent part of this segmented linear feature (043) appeared to have squared terminals (illus 9 ).

Just overlapping the course of the linear segmented feature (037) was a trapezoidal arrangement of post-holes $(036,035,034,042,186,185,183$, $184,044,039$ and 038), the approximate centre of which was occupied by the pit (040). A single sherd of decorated prehistoric pottery was recovered from the fill (160) of a post-hole (034) and another sherd of pottery was recovered from the fill (196) of another post-hole (184) (see Ballin Smith below).

\subsection{Western cluster of pits}

In the western corner of the excavation area (illus 


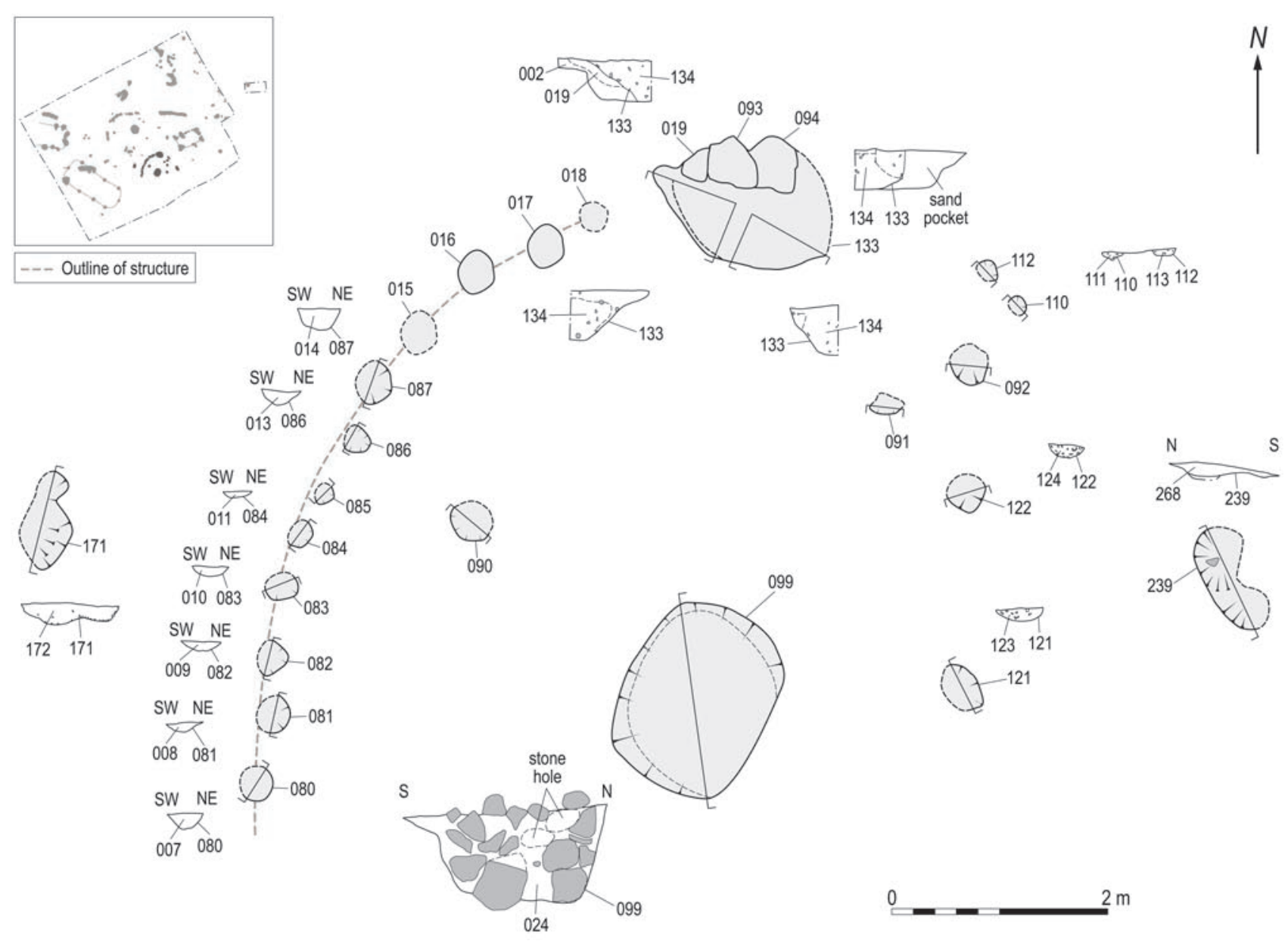

Illus 6 Structure $C$ with details of pits and post-holes

8), was a shallow, nearly circular-shaped pit (250), which contained three fills $(278,277$ and 258). The lower two fills (277 and 278) had no finds and were interpreted in the field as re-deposited natural gravel. Within the upper fill (258), there were packing stones, 24 sherds of Bronze Age pottery, fragments of burnt bone, three lithics/worked stones and some charcoal (see Ballin Smith, Ballin and Ramsay below).

Pit 250 lay at the south-west extremity of a Ushaped arrangement of large pits $(280,251,062$, 061, 060 and 059). The fill (281) of one of the pits (280) contained a single sherd of pottery, while the other pits contained nothing more than occasional charcoal flecks. There was no evidence of post-pipes or packing stones from any of these pits.

\subsection{Miscellaneous features}

North of the linear segmented feature $(065,126$, 037 and 043$)$ were clusters of irregular pits $(270$, $174,204$ and 095$)$ and post-holes $(073,162,075,141$, $143,145,147,148,150,078,219,220,221,222,223$, 224, 225 and 227; illus 9). These features showed evidence of considerable animal disturbance and were generally filled with lenses of re-deposited natural subsoil, apart from the uppermost fill (175) of one of the pits (204), which comprised very dark grey-brown silty sand containing charcoal, with some discolouration caused by burning noted at its base. Another circular pit (61004), encountered slightly to the east during the 2005 evaluation, also contained a large amount of charcoal in its fill (61003) and a discoloured interface between the base of the pit and the fill. Further pits containing evidence for in situ burning included a pit (230) containing fire-reddened gravel (265) at its base, with a charcoal-flecked upper fill (264). These fills had been cut by another pit (229), which also contained a charcoal-rich fill (263). Another similar pit (226) also had a fire-reddened base (267) and a charcoal-rich fill (266). The fill (055) of a tree-throw hole (095) contained charcoal and two sherds of pottery, as did the fill (149) of another post-hole (148). The fill (097) of post-hole 075 contained a large packing stone while another post-hole (078) contained a small fragment of calcified material. To the south of the excavation area were a possible pit (232), a stake-hole (233) and a post-hole (239), and to the west were three small post-holes (252, 253 and 254), none of which appeared to form a coherent pattern or be associated with any other feature. 


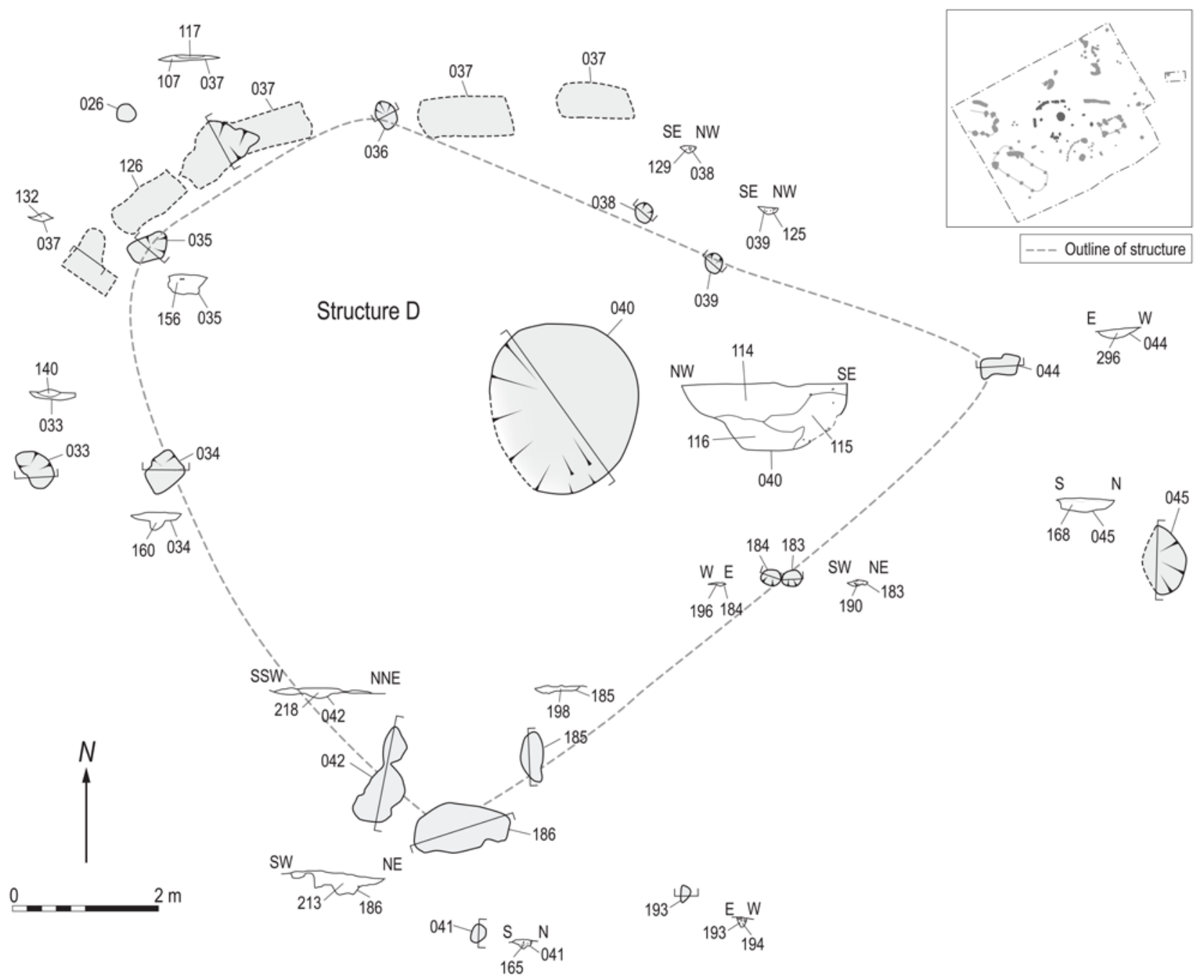

Illus 7 Structure D with details of the central pit 


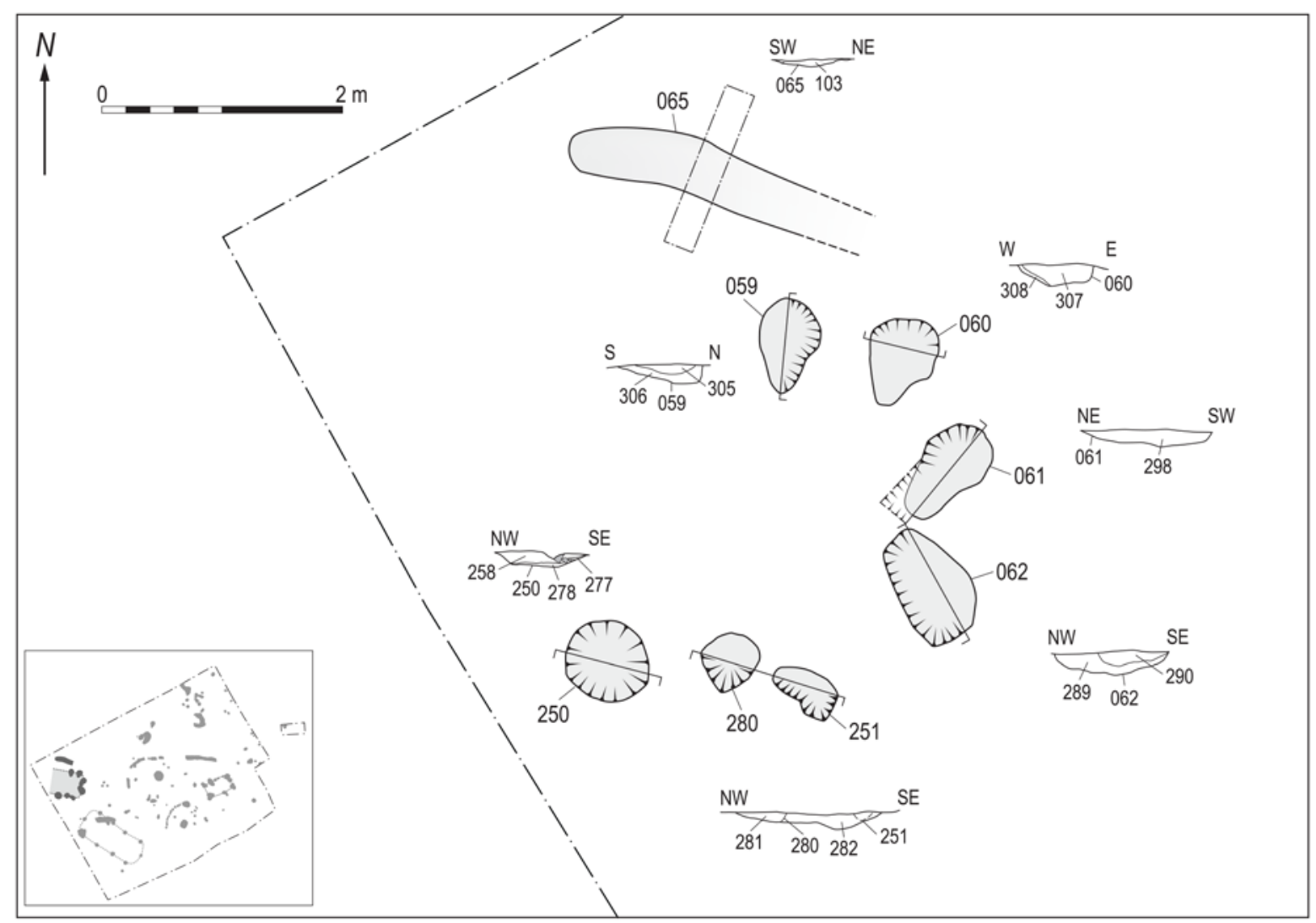

Illus 8 Western cluster of pits with pit profiles 


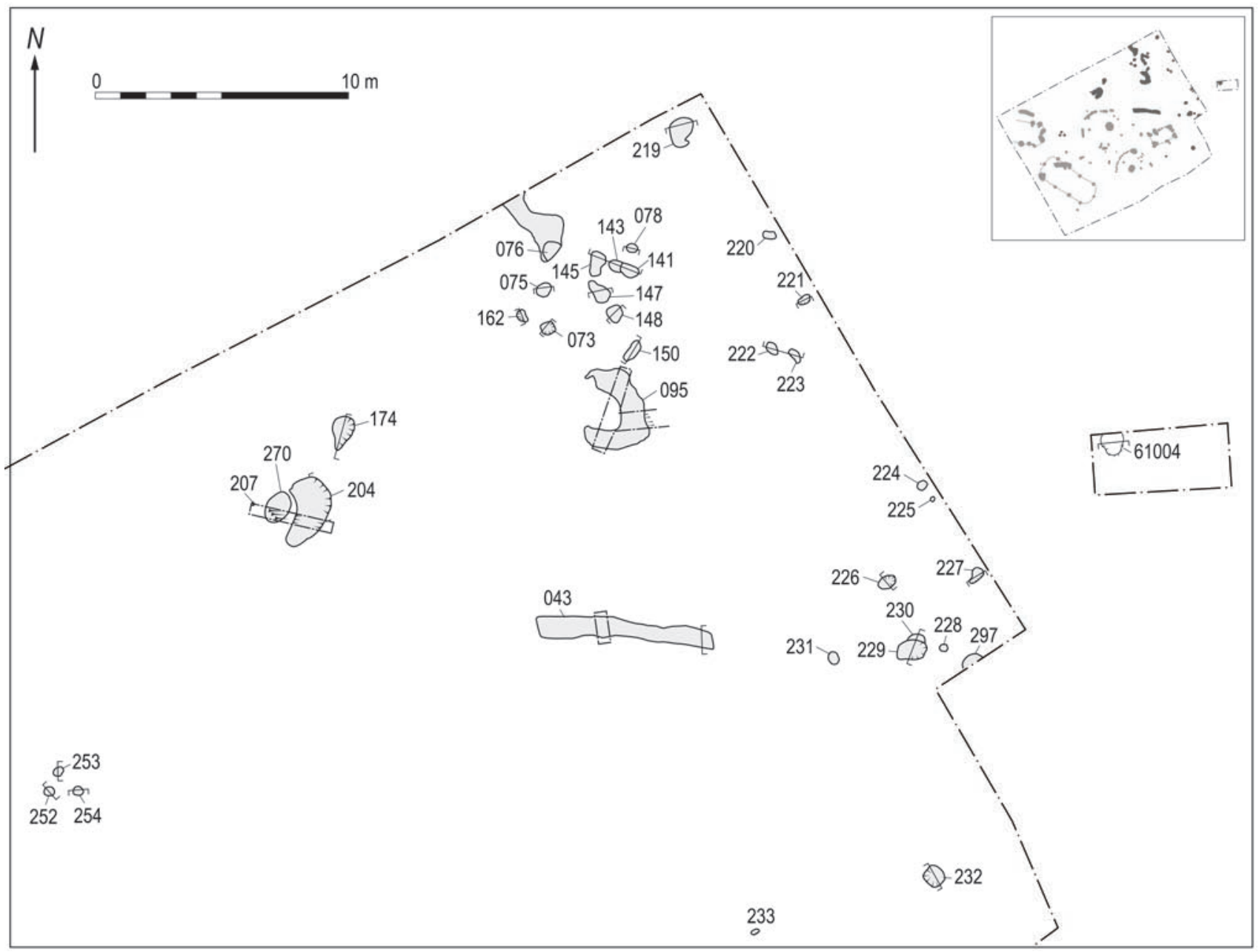

Illus 9 Laigh Newton West-features in the northern part of the site 


\section{LAIGH NEWTON NORTH-WEST, by Heather James, Charlotte Francoz \& Joe Somerville}

A short distance to the north of the Laigh Newton West excavation area (illus 1), on a lower-lying shoulder of the hill, were the remains of a medieval farmstead (James forthcoming). Prehistoric pottery sherds were recovered from unstratified topsoil contexts above these features. Five sherds were recovered from a thick soil deposit (374) and further sherds were recovered from the fills of two linear features (55010 and 55005) during the initial evaluation of this area. One quartz flake was recovered from the loose greyish-brown silt deposit (070) that had accumulated subsequent to the repair of the south-east corner of Structure A, a sunkenfloored medieval building. Another quartz chip was recovered from the post-abandonment deposit (100) from the same building. Several more quartz flakes and chips were recovered from the internal floor (263) and post-abandonment sealing deposits (358 and 395) of a corn-drying kiln. A single quartz chip was recovered from the post-abandonment deposit (295) sealing another structure, and others from the fills (360 and 418) of two of the ditches associated with the farmstead. 


\section{LAIGH NEWTON CENTRAL, by Martin Carruthers \& Kirsteen McLellan}

In 2005, an excavation area was located where previous evaluation trenches in 2003 had noted a cluster of three shallow pits and another pit close to the corner of a rectilinear feature (illus 1). Machine excavation of the $0.2-0.3 \mathrm{~m}$ deep topsoil recovered a variety of unstratified finds including flint and chert flakes, some prehistoric pottery sherds and a fine blade of dark-green Arran pitchstone. Once the topsoil had been excavated, numerous archaeological features were visible above the underlying bands of sand and gravel. Most of the archaeological features comprised discrete features with no demonstrable stratigraphic relationships to each other. However, as with the western concentration of archaeological features, many apparently formed clusters making it possible to recognise probable spatial relationships between individual features (illus 10).

\subsection{Structure E and associated features}

Structure E, first encountered during the 2003 evaluation, was located towards the north-east corner of the excavation area (illus 10 and 11) and was defined by a shallow groove (051). This east/westaligned rectilinear structure measured $5.1 \mathrm{~m}$ in length and $2.3 \mathrm{~m}$ in width. The corners were rounded and the groove varied in width and was generally flat-bottomed. Typically the outer slope was steeper and deeper than that of the inner in each section excavated. Varied preservation meant that depths varied dramatically from $0.28 \mathrm{~m}$ in the betterpreserved portions to just $0.05 \mathrm{~m}$ in the most severely truncated southern part of the groove, where there was also a small gap. While the groove to the east of this gap merely petered out, due apparently to erosion, the groove to the west of this gap tapered to a rounded terminal. The only artefacts to come from the fill of the groove were several fragments of burnt flint and chert.

During the excavation of the north part of the rectilinear groove, a $0.10 \mathrm{~m}$ wide and $0.14 \mathrm{~m}$ deep stake-hole (282) was revealed just to the north of the centre of the groove, with an identical fill (283) to that filling the rectilinear groove. This stakehole coincided with the course of a line of modern disturbance. No trace of further stake-holes was encountered in the groove.

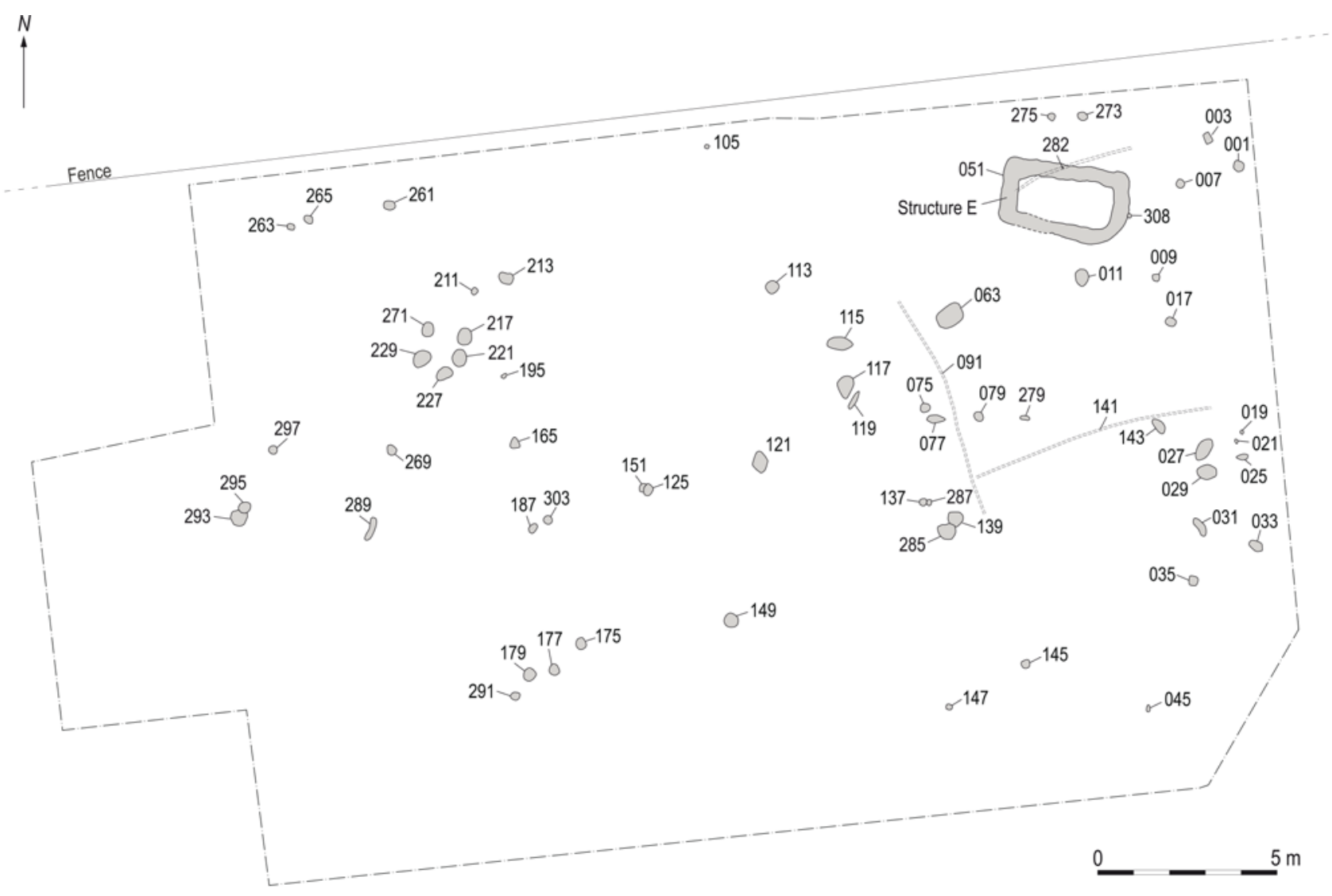

Illus 10 Laigh Newton Central-feature distribution 

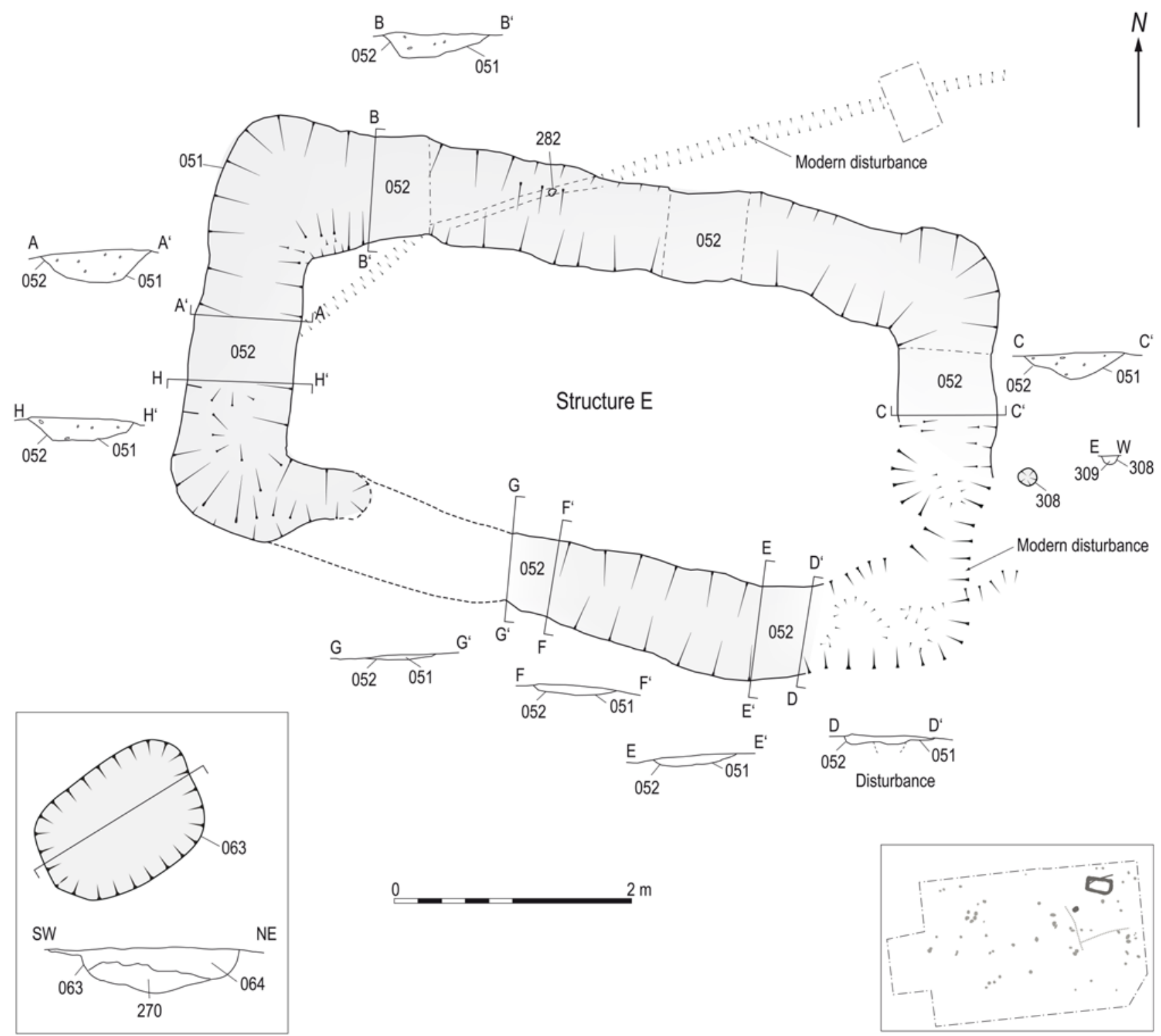

Illus 11 Structure $E$ with feature details

Immediately to the east of Structure E lay a small circular pit (308). The feature lay $c 0.25 \mathrm{~m}$ to the east of the centre of the east 'gable' end of the rectilinear structure. It measured $0.22 \mathrm{~m}$ in diameter and was $0.22 \mathrm{~m}$ in depth with steep sides and a flat bottom, producing a U-shaped profile. The fill (309), a friable mid-brown silty-sand with pea-grit inclusions, contained no artefactual material.

A large rectangular pit (063), $1.7 \mathrm{~m}$ long, $1.10 \mathrm{~m}$ wide, lay $5 \mathrm{~m}$ to the south-west of the rectilinear groove (illus 10 and 11). The pit had rounded corners and possessed a steep-sided but gently rounded bowl-shaped base, $0.4 \mathrm{~m}$ deep in the centre. Two distinct fills were observed. An upper fill (064) of yellow-brown sandy-silt contained small sub-angular inclusions of charcoal flecks and some larger patches of charcoal $0.05-0.25 \mathrm{~m}$ in thickness. Below this deposit was a layer (270) composed almost entirely of charcoal $0.05-0.35 \mathrm{~m}$ in thickness. The upper part of this fill layer comprised large charred fragments of round wood, apparently branches with clearly visible grain, bark and knots of branches arranged in a coherent north-west/south-east orientation as though laid in bundles. One fragment of branch appeared to be cut in two places with diagonal wedge-shaped chopping facets, possibly consistent with axe marks. The lower part of this fill was a dense mass of compacted charcoal with less obvious structure. The excavation revealed that the base of the pit had been affected by heat and reddened in places, indicating in situ burning, and there were several small, rounded cobblestones, apparently pressed into the natural sand subsoil, creating a possible lining. Only two small fragments of flint, one of which was burnt, and a small, heavily worn pottery sherd, were found in the upper fill (064) of this pit (see Ballin and Ballin Smith below). 

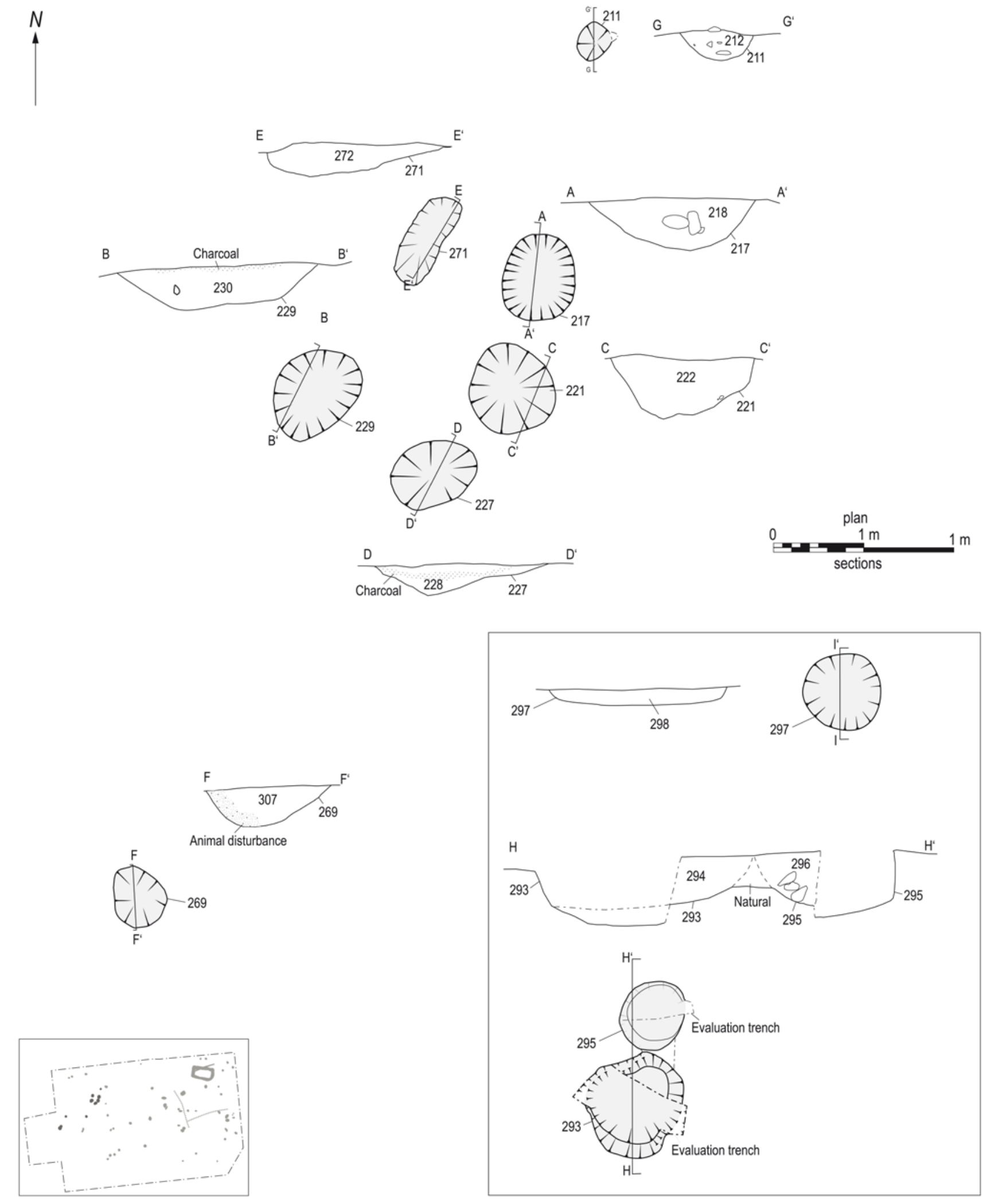

Illus 12 Western pit clusters with details

\subsection{Pit clusters}

Some $30 \mathrm{~m}$ to the west of the rectilinear structure was a cluster of pits (illus 12). These included five large sub-circular pits (229, 227, 221, 217 and 271), of fairly consistent shape and size lying in close proximity to each other. A pit (213) of similar shape and dimensions lay to the north-east, while another cluster of three pits (293, 295 and 297), again of similar size and shape, lay to the south-west. 
A concentration of charcoal containing fairly fine prehistoric pottery sherds was visible just off centre on the surface of pit 229. The fill (230) when half-sectioned revealed that the charcoal lay on the surface only and did not penetrate more than $0.03 \mathrm{~m}$ in depth. In addition to the pottery present on the surface there were additional sherds about $0.15 \mathrm{~m}$ further into the fill within the centre of the pit. These sherds were relatively large, some of them conjoining, from the base of what must have been a fairly large pot. There was also an increased incidence of charcoal in the vicinity of the pot, and several pieces of burnt flint (see Ballin Smith, Ballin and Ramsay below).

Pit 227 lay immediately to the east of pit 229 . The fill (228) contained frequent charcoal inclusions, specks of burnt bone and some small pebbles. At a depth of $0.05 \mathrm{~m}$, a thin lens of more concentrated charcoal was apparent and spread right across the pit. Three sherds of prehistoric pottery were present in the upper part of the fill. Pit 221 was located to the north of pit 227 but contained no artefacts. Pit 217 lay immediately to the north of pit 221 and contained occasional chips and larger chunks of flint, some of which had been burnt. Several larger rounded stones were located towards the centre of its fill (218). Pit 213, to the north-east of this cluster, was an irregularly shaped feature, the fill (214) of which contained a base sherd of prehistoric pottery (see Ballin Smith below).

To the south-west of the main cluster of pits (229, 227,221 and 217) was a cluster of three large pits, first identified during the 2003 evaluation. Two of the pits (293 and 295) were immediately adjacent to each other. Evaluation slots through the centre of these pits were emptied prior to their full excavation. The western upper edge of pit 293 was found to just touch the eastern edge of pit 295 (illus 12). The fill (294) of pit 293 contained seven sherds of pottery and frequent charcoal fragments, with carbonised hazel nutshell fragments and flecks of burnt bone throughout. Pit 295 also contained sherds of prehistoric pottery, numerous burnt bone fragments and charred hazelnut shells, and a triangular flint scraper (see Ballin Smith, Ballin and Ramsay below). Pit 297 yielded two fragments of charred hazel nutshell.

\subsection{Miscellaneous pits and post-holes}

An incoherent pattern of small pits and postholes (195, 211, 233, 235, 265 and 269) was loosely distributed across the excavation area (illus 10). Of these features, only a few were notable, such as a small pit (211) located just $c 2.5 \mathrm{~m}$ to the north-east of pit 217. This circular pit contained frequent charcoal fragments, several carbonised hazel nutshells, a flint blade and six sherds of fine and well-fired pottery, one sherd of which had an everted rolled rim (see Ballin Smith, Ballin and Ramsay below). The fill (304) of another pit (303) contained a small worn sherd of decorated prehistoric pottery. The fill (030) of another pit (029) to the south of the rectilinear groove structure contained barley cereal grains. The remainder of the features varied in shape and were filled with different shades of brown silty sand but contained no artefacts. Two modern field drains (041 and 191 were also observed (illus 10). 


\section{LAIGH NEWTON EAST, by Joe Somerville}

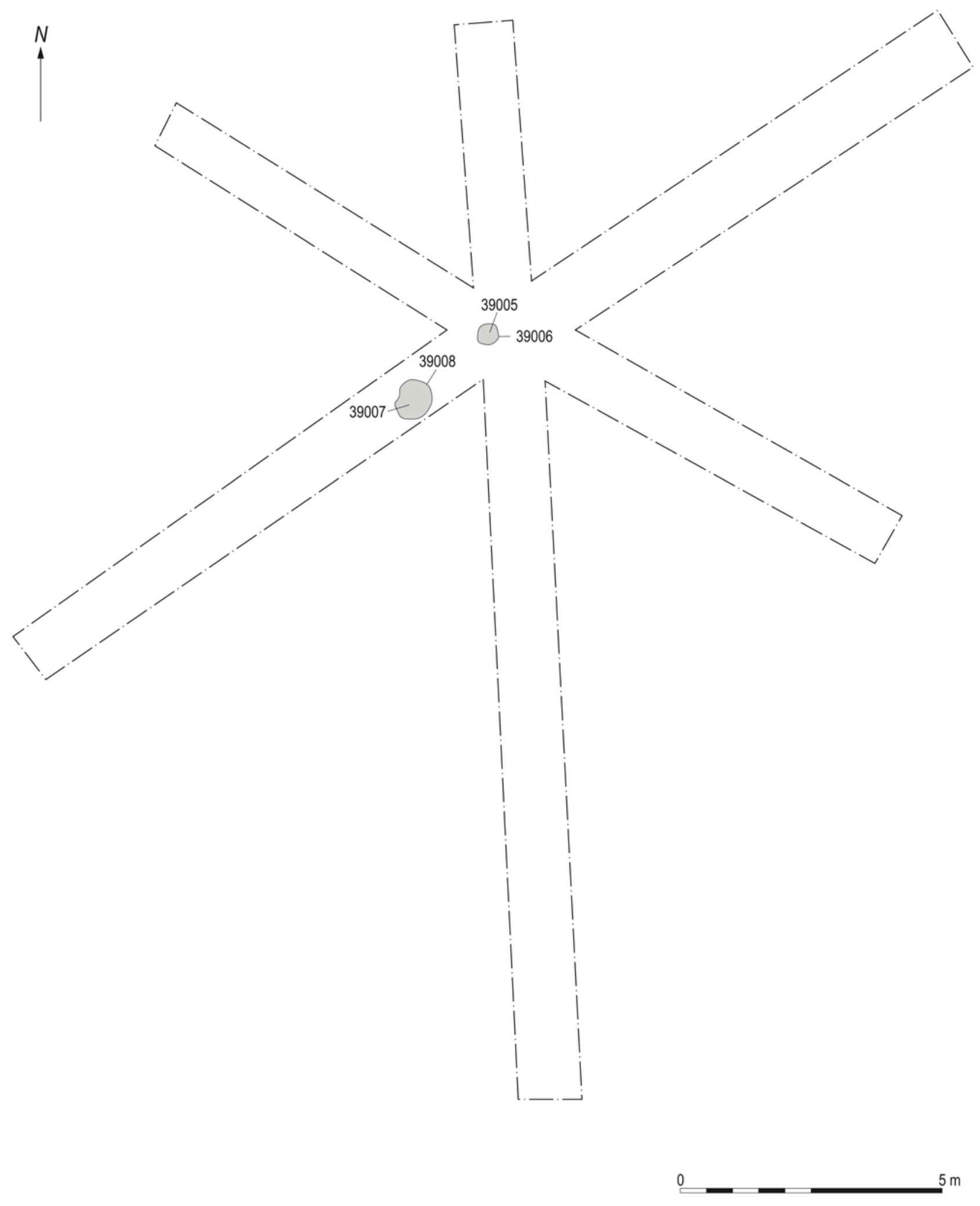


Evaluation trenches in 2005 noted two shallow pits cut into the underlying bands of sand and gravel subsoil within trench 39 (illus 1). Both pits (39006 and 39008) were discrete features with no demonstrable stratigraphic relationship to each other, (illus 13) and their single fills (39005 and 39007) contained flint chips and blades, prehistoric and medieval pottery sherds and carbonised grains (see Ballin Smith, Ballin and Ramsay below). 


\section{SPECIALIST REPORTS}

The following reports summarise the results of the specialist analyses of pottery, daub, lithics and environmental remains recovered from Laigh Newton.
Full specialist reports form part of the site archive held by the Royal Commission for Ancient and Historical Monuments in Scotland (RCAHMS). 


\section{THE POTTERY ASSEMBLAGE, by Beverley Ballin Smith}

\subsection{General observations}

In total, the prehistoric coarse ware pottery recovered from Laigh Newton weighed $1,524 \mathrm{~g}$ (including crumbs). Each collection of sherds from specific contexts has been given a catalogue number (see Appendices 1-4), and this number is used in the text.

The assemblage comprised 195 sherds of prehistoric pottery, which included $17 \mathrm{rims}(c 7.7 \%$ of the assemblage), 166 body sherds (c 87\%) and six base edge sherds $(3.1 \%)$ (table 1$)$. The low percentage of rim sherds is characteristic of many prehistoric sites examined by this author. This, together with the even lower percentage of base edge sherds, is generally typical of domestic sites. Decorated sherds are present but the majority of sherds were plain and carinations, lugs and base sherds absent. The majority of sherds (67\%) were recovered from Laigh Newton Central, with Laigh Newton West and Laigh Newton East yielding $27 \%$ and $21 \%$ of the assemblage respectively. A minimum of 16 vessels was recorded (see table 2), dating from the Early Neolithic to the Bronze Age.

The assemblage was homogenous. Much of the temper was medium to coarse in size, comprising

Table 1 Distribution of sherd forms across the excavated areas

\begin{tabular}{|c|c|c|c|c|c|c|}
\hline Area & Trench & Rims & Bodies & Base/b. edge & Crumbs & Total \\
\hline Laigh Newton East & 2028 Tr. 39 & 7 & 32 & 2 & $\checkmark$ & 41 \\
\hline \multirow[t]{2}{*}{ Laigh Newton Central } & 1259 & 2 & 19 & - & $\checkmark$ & 21 \\
\hline & 2028 & 5 & 69 & 2 & $\checkmark$ & 76 \\
\hline Laigh Newton West/Area A & 2420 & 3 & 40 & 1 & $\checkmark$ & 44 \\
\hline \multirow[t]{3}{*}{ Laigh Newton West/Area B } & 2420 & - & 5 & 2 & - & 7 \\
\hline & $2028 \operatorname{Tr} .55$ & - & 1 & - & - & 1 \\
\hline & $2028 \operatorname{Tr} .57$ & - & - & - & $\checkmark$ & 0 \\
\hline Totals & & 17 & 166 & 7 & $\checkmark$ & 190 \\
\hline
\end{tabular}

Table 2 Minimum number of pottery vessels

\begin{tabular}{lll}
\hline Vessel No. & Catalogue No. & Type \\
\hline 1 & 6,8 & Early Neolithic bowl \\
2 & 7 & Early Neolithic bowl \\
3 & $9,10,11,12$ & Early Neolithic bowl \\
4 & 13,16 & Neolithic \\
5 & 15,18 & Neolithic \\
6 & 31 & Bronze Age Urn \\
7 & 40 & Grooved Ware \\
8 & 45,48 & Early Neolithic \\
9 & 51,56 & Impressed Ware/Grooved Ware \\
10 & 57 & Impressed Ware/Grooved Ware \\
11 & 62,63 & Early Neolithic bowl \\
12 & 66,78 & Beaker vessel \\
13 & 68,71 & Early Neolithic bowl \\
14 & 72 & Grooved Ware \\
15 & $69,73,74,75,76,77$ & Beaker vessel \\
16 & 83 & Neolithic \\
\hline
\end{tabular}




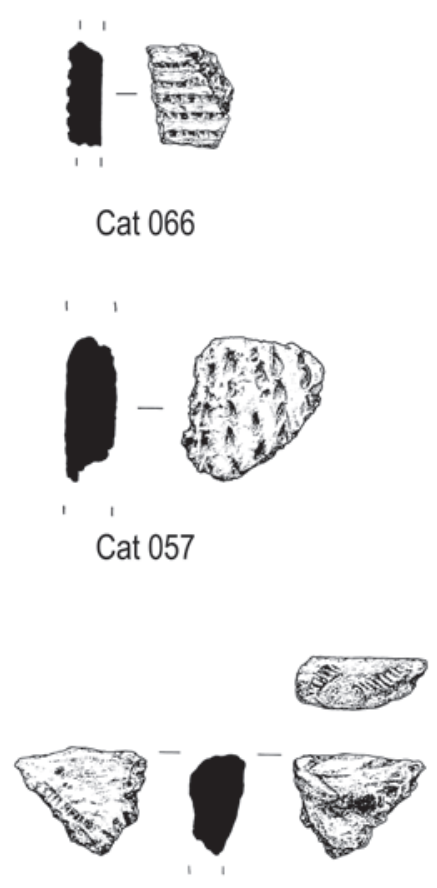

Cat 063
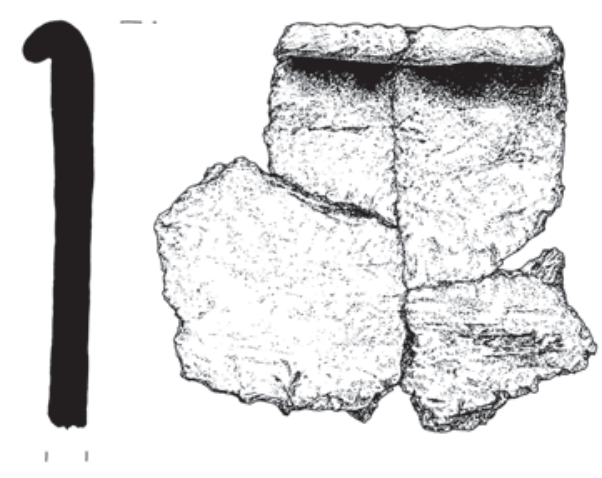

Cat 006

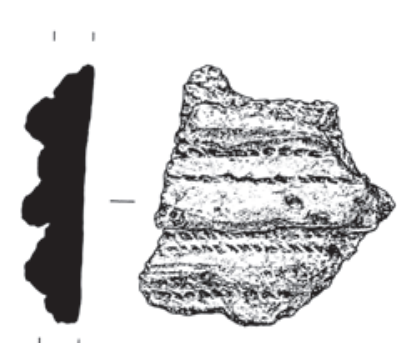

Cat 072
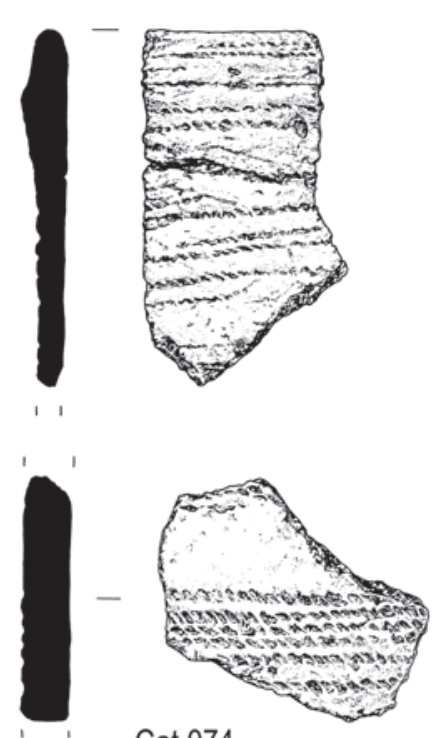

Cat 074

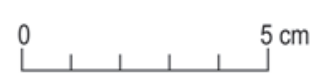

Illus 14 Prehistoric pottery: Catalogue nos: 6 Early Neolithic bowl fragment, 57 Impressed / Grooved Ware vessel fragment, 63 Early Neolithic vessel fragment, 66 Beaker vessel fragment, 72 Grooved Ware vessel fragment, 74 Beaker vessel fragments

ill-sorted chunks of rock, predominantly quartz, with mudstone, shale and small pebbles of unidentified rocks. Some sand was also present but the identification of vegetable temper was difficult due to the weathering of the pottery, and was only positively identified in sherds from Laigh Newton East. The red/orange clay for the pottery is likely to have come from the banks of the River Irvine. It may have included naturally occurring flecks of mica, or mica may have been deliberately added. Some of the slip that was used on the earliest vessels also included mica.

Crumbs of broken-down sherds, indicating the fragmentation and condition of the pottery, were present in all excavation areas. There was a reasonably narrow range of sherd thickness across all sites, possibly suggesting that there was not a great variety in form and function over time. Excluding Catalogue 87, the thinnest sherds were found in the eastern and western excavation areas and these are likely to be the oldest dated pottery (see below). The thicker sherds from Laigh Newton Central suggest that either the pottery was heavier and therefore of a different period from that found in the other areas, or there was a range of different types of vessels from different periods.

Overall the preservation of the pottery was poor, with rare exceptions. The fracturing of the pottery after its deposition and the abrasion of its edges has largely been the result of post-primary depositional changes. While ploughing is an obvious cause of abrasion of sherd surfaces and edges, the abrasion of pottery from features below the plough truncation horizon implies that these contexts are secondary to the initial deposition of the pottery. It has also been demonstrated that pottery derived from close to the edge of Laigh Newton West moved downhill due to soil creep and was located in the thick topsoil covering the western part of Laigh Newton Northwest. Although these sherds did not join, they were from the same vessel (Catalogues 84-86).

All the pottery from Laigh Newton was slab- or coil-built using local raw materials. There was little differentiation between one vessel and another except in its form and surface treatment. Only three main types of vessel were identified: cooking pots, storage wares and Beakers.

Those rims that survived were mainly rolled or folded over and everted, and it was possible to measure the diameter of only three of them. Two vessels, Catalogue 6 (illus 14) and Catalogue 10, from Laigh Newton East had diameters of $200 \mathrm{~mm}$ and $220 \mathrm{~mm}$ and Catalogue 13 from the central excavation area was similar, with a measurement of $210 \mathrm{~mm}$.

Approximately $48 \%$ of the assemblage exhibited 
evidence of surface treatments. The majority of these were acquired by the vessel during the manufacturing process and before firing. These hand-made vessels were treated by smoothing, slipping (including the addition of mica dust), burnishing, wiping and knife finishing. These processes are commonly noted on prehistoric vessels where the irregularities of slab and coil building and the use of coarse gritting temper could be removed by smoothing the wet clay of the exterior surface with the hands or wiping it with a cloth or dried grasses. Interiors of vessels were also smoothed but in many cases their subsequent use has removed any trace of treatment. Once partially dried, a thin clay slip was applied to some vessels into which a ground mineral such as mica may have been added, which would give the vessel a shiny appearance after burnishing and firing. Slipped vessels were usually burnished or polished by a smooth stone, bone or piece of wood. Burnishing would usually remove the last irregularities and produce a hard and shiny surface, and nearly one-third of the assemblage was finished using this technique. Cooking pots could receive other surface treatments but burnishing was usually reserved for vessels that were not put directly in the fire or on the hearth. The folded or rolled rims on the majority of rim sherds from Laigh Newton East were trimmed by a knife (Catalogues 1, 2, 6-10 and 12), as was a rim from Laigh Newton West (Catalogue 72). Accidental evidence from the pottery manufacture included the impressions of fingertips and from vegetable matter such as grasses or straw.

Residues found on this and other assemblages were of soot and carbonised or burnt food deposits and are commonly found on prehistoric and later vessels. At Laigh Newton they were found on pottery from all the major areas. Sooting is usually found on the exterior of pots which were used close to or in a hearth, while carbonised food deposits are most frequently found on the rims (both internally and externally), shoulders and body of vessels. One plain cooking pot (Catalogues 15 and 18) from Laigh Newton Central had continued to be used when damaged as the evidence of burnt food deposits in a crack indicated.

Decorated sherds were mainly found on vessels and sherds in Laigh Newton West, with rare examples in Laigh Newton East and Central. Apart from finger indentations which are likely to be accidental in this assemblage, there was a range of other types of decoration, including striations, nicks and pinches, linear and combed incisions, incised dots, applied cordons and cord impressions. Incisions and impressions were the most common and included the use of a tool such as a pointed stick, quill, comb or cord to make a surface decoration on vessels while their surfaces were still drying prior to firing. Impressions of single twisted cords were found on the surfaces of a Late Neolithic Grooved Ware Vessel (Catalogue 72 (vessel 14); illus 14) and a Late Neolithic Beaker (Catalogues 69, 73, 74, 75, 76, 77 (vessel 15); illus
14) from Laigh Newton West. There were also two examples in the assemblage, a Grooved Ware body sherd (Catalogue 72) from Laigh Newton West and another Grooved Ware body sherd (Catalogue 51) from Laigh Newton Central, where extra strips or roundels of clay were added to the exterior surfaces as decorative elements. A further seven body sherds (Catalogues 8, 40, 57, 66, 78, 68 and 79) from the east, west and central excavation areas and two rims (Catalogues 62 and 63) from the west excavation area were decorated by either stabbing, incising or combing using narrow and slightly broader pointed implements (illus 14).

\subsection{The Laigh Newton West assemblage}

The largest number of sherds and the greatest range of vessels from the western excavation area derived from the upper fill (258) of pit 250 on the western edge of this site. A Beaker vessel, possibly with All-Over Cord decoration and a surviving base with a diameter of $70 \mathrm{~mm}$, formed the largest part of the assemblage from this pit (Vessel 15; Catalogues $69,73,74,75,76$ and 77 ; illus 14). Sooting and carbonised food deposits were present on its sherds, indicating it was used on a hearth or close to a pyre. The Beaker vessel is considered to be from the latter part of the Late Neolithic into the Early Bronze Age. Possibly contemporary with this was a sherd of a highly decorated Grooved Ware vessel (Vessel 14; Catalogue 72; illus 14). The sherd was from close to the rim of the vessel, and again it had carbonised food deposits. Two sherds from a well-burnished early Neolithic vessel (Vessel 13; Catalogue 68 and 71) and a sherd from another (Catalogue 70) of unspecified Neolithic date were also found in the same pit fill.

One sherd (Catalogue 78) from another Beaker vessel(Vessel 12), with combed rather than impressed decoration, was incorporated into the lower fill (278) of pit 250 while another sherd (Catalogue 66) from the same vessel was recovered from the fill (160) of a small post-hole (034) within Structure D near the centre of the site. Only two of the other pits arranged near the north-west corner of Laigh Newton West yielded any pottery. One undated sherd of pottery (Catalogue 79) with a fingernail impression was found in pit 280, to the immediate east of pit 250 and was the only sherd from this pit. Another single sherd of heavily eroded pottery (Catalogue 80 ) was found in pit (060) slightly to the north.

A single and very small sherd of possibly another Beaker vessel (Catalogue 82) was found in the topsoil, while a partly decorated and carinated Early Neolithic vessel (Vessel 11) was represented by sherds (Catalogues 62 and 63) from the fill (055) of a banana-shaped feature (095) in the northeastern part of the site. No other diagnostic pottery was associated with this area.

Other small, plain undiagnostic sherds were sparsely distributed in other features across the 
central parts of this site, but they throw little light on the form and function of vessels they represent.

\subsection{Laigh Newton North-west}

Topsoil and unstratified sherds from across this site (Catalogues 84-86) were very similar to each other and possibly came from the same Neolithic cooking vessel, as carbonised food deposits were common. All seemed to be residual prehistoric sherds, which due to topsoil creep and centuries of ploughing had probably moved downhill from their most likely origin at Laigh Newton West.

\subsection{Laigh Newton Central}

During the evaluation, sherds of a large, plain but well-finished Early Neolithic vessel (Vessel 4; Catalogues 13 and 16 ), with a rim diameter of $210 \mathrm{~mm}$, were found in the fill (298) of a small pit (297). The presence of sooting and carbonised food deposits suggests that this vessel functioned as a cooking pot. Other small sherds from possibly one vessel (Vessel 5; Catalogues 15 and 18) were found in nearby pits (295 and 293). From the characteristics that remain, the vessel was plain but it did not have evidence of burnishing. The internal carbonised food deposits and the fact that the vessel was used when cracked, indicate that it too was a cooking pot. The date of the vessel is less certain than for Vessel 4, but it is likely to be Neolithic.

Further excavation of pit 295 recovered an Early Neolithic vessel (Vessel 17; Catalogues 53 and 55) along with a coarse-tempered Bronze Age body sherd (Catalogue 52). Another sherd (Vessel 9; Catalogue 51) from the same pit fill had an applied boss and may have derived from an Impressed Ware bowl or Grooved Ware bucket-type vessel of Middle to Late Neolithic date. Pit 293 contained further evidence of an Early Neolithic cooking pot (Vessel 8; Catalogues 45 and 48). However, sherds from a less well-finished vessel (Catalogue 46) with surface grass marks, suggest a coarser type of cooking vessel was also present in this pit fill.

The fill (304) from a pit (303) situated to the immediate south of these pits, contained a sherd from another Impressed Ware or Grooved Ware vessel (Vessel 10; Catalogue 57). The deposition of this highly burnished sherd must be considered with the activities and functions associated with the nearby group of pits.

The group of pits in the north-western area of Laigh Newton Central also produced pottery. Many of the sherds were small and the assemblage contained a high proportion of crumbs. A small rim from one of these pits (211) is probably Neolithic in date but the rest of the undistinguished and eroded sherds were from a plain vessel, possibly of Bronze Age date. Coarse sherds (Catalogue 31), possibly from an Early to Middle Bronze Age urn fragment, were found within the fill (214) of pit 213. Evidence from the fill (228) of another pit (227), which included inturned rims with slight shoulders, suggests vessel(s) also of Bronze Age date. The pottery was very fragmentary and the lack of surface detail prevented these sherds from being defined further. The fill (230) of another pit (229) in this group produced a sherd (Catalogue 40), likely to be from a Grooved Ware vessel, spanning the latter part of the Early Neolithic or the early part of the Later Neolithic. Although the surface finish was lost, this sherd is likely to have derived from a bucket-shaped vessel with all-over surface decoration. A fragment of a possible Early Neolithic vessel (Catalogue 41) was also found in the same context (230).

The rest of the material from this site was mixed; generally the sherds were small and fragmented; there were many crumbs and much loss of surface detail.

\subsection{Laigh Newton East}

All the pottery, predominantly Early Neolithic bowls, came from the fills of two isolated pits (39005 and 39007) and was characterised by plain, straightnecked, thin bowls with the addition of a thicker baggy bowl (see Appendix 4). Although there was no evidence for any carinations, the bowls (a minimum of three e.g. Catalogue 6, illus 14) are likely to date to the Early Neolithic and form part of the Carinated Bowl tradition. Carbonised food remains are common, indicating the use of the vessels for cooking rather than storage. They may also have been used for serving food and drink (Sheridan 2007, 213).

\subsection{Comparison, chronology and conclusions}

The assemblages from Laigh Newton derive from features associated with Neolithic and Bronze Age domestic activities. Laigh Newton East yielded only pottery of one period - the Early Neolithic, while Laigh Newton Central spanned the Early Neolithic to some time in the Bronze Age, most likely the early to middle part of that period. The identification of diagnostic sherds from Laigh Newton West suggests that this site was occupied from the Early Neolithic through to the Late Neolithic/Early Bronze Age.

Early Neolithic vessels found on the excavated areas at Laigh Newton are part of the 'Carinated Bowl' pottery tradition, which was widespread in domestic situations across Scotland and further afield. Recent examples of this type of pottery have been found in East Lothian during archaeological works along the A1 trunk road (Sheridan 2007, 213).

The incidence of small sherds from four separate vessels (Vessels 7, 9, 10 and 14) likely to belong to either the Early Neolithic Impressed Wares or the later Grooved Ware pottery traditions is considered important. Grooved Ware sites in southern Scotland 
are rare, and the nearest geographically to Laigh Newton are those of Biggar Common (MacSween 1995, 454) and Dreghorn (Addyman 2004, 87-90). Small fragments of Grooved Ware vessels were also found during the A1 excavations in East Lothian (Sheridan 2007, illus 4.14). The most productive Scottish sites with the widest range of decorative elements are those from Orkney. Recently published work from Barnhouse (Jones 2005, 261-281) and Pool (MacSween 2007, 287-306) update the existing knowledge about the range of styles and plastic ornament for this pottery type.

Vessel 14 (Catalogue 72) is particularly interesting in that it has both applied decoration and cord impressions. The incidence of the latter technique seems to be rare and may indicate that the piece is late in date, manufactured at a time when Beakers with All-Over Cord decoration were in circulation.

Beaker pottery from the end of the Neolithic and the beginning of the Bronze Age was the most numerous vessel type at Laigh Newton West, and it was only found there. At least two separate vessels were identified; one had combed decoration and the other was cord-impressed. An All-Over Cord Beaker sherd was found in 1953 at the Roman fort at Loudoun Hill but there are no other finds of this type recorded in the near vicinity of the site (Clarke 1970, 514). One vessel (Catalogue 31) from Laigh Newton Central was tentatively identified as a Bronze Age urn. It was undecorated and quite likely to date late in the Middle Bronze Age period. No other vessels were associated with it, nor was there evidence of a cremation. Plain burial urns are commonly found with highly decorative ones, as those from recent work on the shores of Loch Lomond (Ballin Smith forthcoming) attest, and their dates tend to lie within the 1900-1600 cal BC range (Sheridan 2007, 164-5).

There has been little archaeological work in East Ayrshire and surrounding districts that has produced a range of vessel types and dates comparable to those recovered from Laigh Newton. 


\section{THE DAUB AND OTHER CLAY MATERIALS, by Beverley Ballin Smith}

A small assemblage of a total of 13 pieces of daub or clay came from across the central and western areas of the site (see Appendix 5). Only a few of these pieces contained evidence of being directly associated with wattle hurdles, but catalogue nos 24 and 37 from the central area were positively identified as daub. Most of the rest of the pieces were very small, rolled and heavily abraded, and their positive identification as daub is less secure.

Daub is earth with clay, sand, small stones, straw, dung or grass, which was used as a building material and was applied to wooden buildings to make them wind- and water-tight throughout prehistory. The use of daub continued into historical times as a common infilling to wooden-walled buildings (see Graham 2003). Occasionally daub was burnt in situ to harden it (Shaffer 1993), and it is burnt daub which survives longest in the archaeological record, although not all the Laigh Newton examples were burnt. The occurrence of this small assemblage indicates the presence of wooden structures at Laigh Newton and that clay or daub were also used for purposes other than building. However, it is not thought likely that any of this assemblage derived from the clay lining to a furnace as there was no evidence of slag from any of the sites.
The colour of daub varied from pale brown through reddish yellow to orange to pale grey, and the pieces were extremely light in weight. The total assemblage weighed $20.9 \mathrm{~g}$, equivalent to a little over $1 \mathrm{~g}$ per piece. The lightness was probably due to the burning away of strengthening materials such as straw or grass, which were added to prevent shrinking and cracking, and to provide some flexibility (Pritchett 2001; Graham 2003, Section 4.30) Evidence of this can be seen as impressions of a seed in Catalogue 58 from the west area.

A small number of fine flat pieces were possibly part of a clay/daub artefact or plaque with smoothed surfaces and slightly rounded edges (Catalogue 58), which came from an evaluation trench south of Laigh Newton West. The actual shape of the artefact could not be reconstructed from the three fragments which joined. Catalogue 67 was also a small roundel of clay/daub.

Daub is often an underrepresented man-made material on archaeological excavations. Its soft, loose structure leaves it vulnerable to decay and abrasion but its presence at Laigh Newton indicates there were wattle and daub structures on the central site, or close by. Two pieces from the western area were probably artefacts, but there is little decisive about their form. 


\section{THE LITHIC ASSEMBLAGE, by Torben Bjarke Ballin}

In total, 74 lithic artefacts were recovered from the Laigh Newton excavations (table 3). Thousands of unworked lithic pieces from sieved samples were discarded. The purpose of this analysis was to characterise the lithic assemblage in detail, with special reference to raw materials, typological composition and technology. From this characterisation, it was sought to date the lithic assemblage and discuss its affiliation. The evaluation of the lithic assemblage was based upon a detailed catalogue of all the lithic finds from Laigh Newton, and the artefacts in this report are referred to by their number (CAT) in the catalogue (see Appendix 6).

The definitions of the main lithic categories are as follows:
- Chips: All flakes and indeterminate pieces the greatest dimension (GD) of which is $\leq 10 \mathrm{~mm}$.

- Flakes: All lithic artefacts with one identifiable ventral (positive or convex) surface, GD $>10 \mathrm{~mm}$ and $\mathrm{L}<2 \mathrm{~W}(\mathrm{~L}=$ length; $\mathrm{W}=$ width).

- Indeterminate pieces: Lithic artefacts which cannot be unequivocally identified as either flakes or cores. Generally the problem of identification is due to irregular breaks, frost-shattering or fire-crazing. Chunks are larger indeterminate pieces, and in, for example, the case of quartz, the problem of identification usually originates from a piece flaking along natural planes of weakness rather than flaking in the usual conchoidal way.

Table 3 Lithic artefact list

\begin{tabular}{|c|c|c|c|c|c|}
\hline & $\begin{array}{l}\text { Laigh } \\
\text { Newton } \\
\text { West }\end{array}$ & $\begin{array}{c}\text { Laigh } \\
\text { Newton } \\
\text { North-west }\end{array}$ & $\begin{array}{l}\text { Laigh } \\
\text { Newton } \\
\text { Central }\end{array}$ & $\begin{array}{l}\text { Laigh } \\
\text { Newton } \\
\text { East }\end{array}$ & Total \\
\hline \multicolumn{6}{|l|}{ Debitage } \\
\hline Chips, flint & 1 & 2 & 2 & 12 & 17 \\
\hline Chips, quartz & 4 & 7 & & & 11 \\
\hline Flakes, flint & 4 & & 4 & & 8 \\
\hline Flakes, quartz & & 5 & 5 & & 10 \\
\hline Flakes, chert & & 1 & 1 & & 2 \\
\hline Flakes, agate & & & 1 & & 1 \\
\hline Blades, flint & & & 1 & & 1 \\
\hline Blades, pitchstone & & & 1 & & 1 \\
\hline Microblades, flint & & & & 9 & 9 \\
\hline Microblades, pitchstone & 1 & & & & 1 \\
\hline Indeterminate pieces, flint & & & 3 & & 3 \\
\hline Total debitage & 10 & 15 & 18 & 21 & 64 \\
\hline \multicolumn{6}{|l|}{ Tools } \\
\hline Short end-scrapers, chert & & 1 & & & 1 \\
\hline Discoidal knives, flint & & & 1 & & 1 \\
\hline Truncated pieces, flint & & 1 & & & 1 \\
\hline Denticulated pieces, quartz & & 1 & & & 1 \\
\hline Fragments of polished implements, flint & & & 1 & & 1 \\
\hline Pieces with edge-retouch, flint & 2 & & 1 & & 3 \\
\hline Pieces with edge-retouch, chert & & & 1 & & 1 \\
\hline Pieces with edge-retouch, pitchstone & & 1 & & & 1 \\
\hline \multirow[t]{2}{*}{ Total tools } & 2 & 4 & 4 & & 10 \\
\hline & 12 & 19 & 22 & 21 & 74 \\
\hline
\end{tabular}


- Blades and microblades: Flakes where $\mathrm{L} \geq 2 \mathrm{~W}$. In the case of blades $\mathrm{W}>8 \mathrm{~mm}$, in the case of microblades $\mathrm{W} \leq 8 \mathrm{~mm}$.

- Cores: Artefacts with only dorsal (negative or concave) surfaces - if three or more flakes have been detached, the piece is a core, if fewer than three flakes have been detached, the piece is a split or flaked pebble.

- Tools: Artefacts with secondary retouch (modification).

\subsection{General observations}

The assemblage was clearly dominated by flint (60\%) and quartz (30\%), supplemented by some chert (5\%) and pitchstone (4\%), as well as a solitary piece of agate (1\%). The agate flake (CAT 9) may be natural. It is possible to sub-divide the flint into two main forms, namely a south-west Scottish form and an exotic (imported) form ('Yorkshire flint'; Saville 1994, 63). The former is generally light and opaque, and it may include some impurities, whereas the latter is more vitreous, homogenous and usually darker. The south-west Scottish flint type may have been procured along local shores, but as this form of flint is also found in Northern Ireland (ibid, 63 ), it is almost impossible to determine whether an individual piece represents procurement from Scottish sources or importation, unless the object has surviving cortex: abraded cortex would indicate procurement from a local pebble source, whereas a fresh, powdery surface suggests that the piece was obtained from primary sources in County Antrim. In the case of Laigh Newton, there are no indications that flint may have been imported from Antrim.

Yorkshire flint was exchanged in two sub-forms, a dark-brown, pure form and a dark-grey, slightly less vitreous, marbled form. The finds from Laigh Newton include both these types. However, only the former is absolutely certain to derive from north-east England, as the latter is more similar in appearance to the south-west Scottish/Antrim type, with mis-identification being a possibility. Although recent research into Scottish imported flint reveals that Yorkshire flint may have been imported into south-east Scotland already in the later part of the Early Neolithic (Ballin forthcoming a), in most parts of Scotland, Yorkshire flint is largely associated with the Late Neolithic Levallois-like technology (Ballin forthcoming b) and the production of arrowheads and cutting implements. The exchange in Yorkshire flint seems to tail off in the Early Bronze Age period. Eight pieces of flint (CAT 3, 13, 15-6, 32-3, 48 and 50), from Laigh Newton West and Central were thought to be in this material (almost one-fifth of all flint artefacts).

The quartz artefacts were generally homogenous white, milky quartz with acceptable flaking properties, although two transparent chips (CAT 30 and 37) were rock crystal. Quartz occurs in sedimentary and igneous as well as metamorphic rock formations
(Pellant 1992, 86), but the abraded cortex of several pieces suggests procurement from beach or river deposits. The chert (CAT 1, 4 and 25) corresponds to what is generally known as Southern Uplands chert. Southern Uplands chert occurs in many colour variations, with black, grey, blue-green/grey-green, and brown/brown-green being the most common varieties. Though banding does occur, the Laigh Newton chert is generally plain or lightly speckled, light- to dark-grey, radiolarian chert. Scottish chert is particularly common in Carboniferous Limestone (Ballin \& Johnson 2005, 62), but it also occurs in some earlier and later sedimentary formations, such as Ordovician and Silurian formations (Cameron \& Stephenson 1985). At Laigh Newton, the chert was most likely to have been procured from local Carboniferous outcrops (Woodland 1979).

Three artefacts (CAT 5, 20 and 26) in Arran pitchstone (Williams Thorpe \& Thorpe 1984) are black, aphyric volcanic glass with a green tinge. The pieces were generally very homogeneous, with small spherulites, but few macroscopically visible crystallites (Ballin \& Faithfull 2009). CAT 26 was slightly banded. Although some porphyritic sources (for example at Tormore and Auchagallon on Arran's west coast) have narrow bands of aphyric material, the Laigh Newton specimens were so homogeneous that they are unlikely to have been procured from areas outwith the wider Corriegills district on Arran's east coast. CAT 9 appears to be a small agate flake, but the piece is relatively irregular and may be natural. Although there were numerous pieces of chalcedony/agate in the material from the site's sieved samples, this raw material was apparently ignored by the inhabitants. The related raw materials chalcedony, agate and jasper generally derive from igneous formations.

Laigh Newton West and Central had roughly the same distribution of raw materials, with almost $60 \%$ flint, approximately one-third quartz/chert (poorquality supplementary raw materials) and 5-8\% pitchstone (one piece each). Laigh Newton Northwest was dominated by the poorer raw materials quartz and chert (almost 80\%), with $16 \%$ flint and, again, a single piece of pitchstone. Laigh Newton East stands out, with its sub-assemblage being exclusively in flint.

\subsection{Laigh Newton West}

The sub-assemblage from the westernmost site included twelve pieces, ten of which were debitage, with two being tools. The debitage consisted of one flint chip, four flint flakes and four quartz flakes, as well as one pitchstone microblade. Flint flakes CAT 32 and 33 probably represent importation from north-east England. Both tools (CAT 21 and 29) were flints with simple edge-retouch, one of which was on a blade and one on a microblade. Technologically definable blanks were detached by soft as well as hard percussion. 


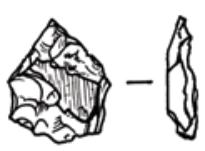

Cat 3

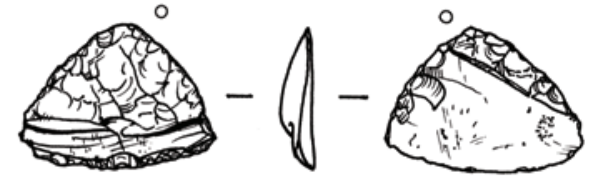

Cat 15

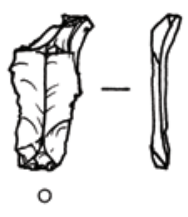

Cat 23

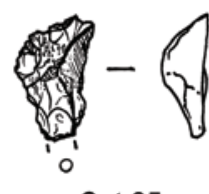

Cat 25

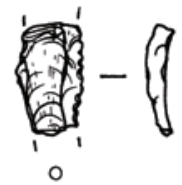

Cat 26 $5 \mathrm{~cm}$

Illus 15 Lithics: Catalogue nos: 3 Polished piece of probable Yorkshire Flint; 15 Late Neolithic scale flaked knife of probable Yorkshire Flint, 23 Flint blade with oblique truncation, 25 Chert short end-scraper flake, 26 Pitchstone blade with edge-retouch

The modified flint microblade (CAT 29) was detached by the application of soft percussion. The production of microblades, as well as the use of soft-hammer technique, are characteristics of the Late Mesolithic period and the earliest part of the Early Neolithic (see for example Ballin 2006; Ballin forthcoming c). This piece was local flint. In terms of size and general execution, it corresponds to the microblades from the small concentration at Laigh Newton East.

The two small flakes (CAT 32 and 33) in Yorkshire flint are most likely to date to the later part of the Neolithic period and were recovered from the same feature (pit 040) as an undiagnostic flint flake (CAT 19).

Amongst the upper level packing stones of pit 250 in the north-western corner of the western excavation site, two diagnostic lithics were retrieved, namely a pitchstone microblade (CAT 20) and a retouched flint blade (CAT 21). The examination of pitchstone artefacts in connection with the author's recent pitchstone project suggests that, on the Scottish mainland outside Argyll, pitchstone use was largely an Early Neolithic phenomenon (Ballin 2009). In Scotland, broad blades of the size of CAT 21 usually date to the middle or later Neolithic period (Ballin forthcoming a).

\subsection{Laigh Newton North-west}

The sub-assemblage from Laigh Newton Northwest included nineteen pieces, fifteen of which were debitage, with four being tools. The debitage consisted of two flint chips, seven quartz chips, five quartz flakes and one chert flake. This subassemblage included no exotic flint. The four tools comprised one end-scraper on a short chert flake (CAT 25; illus 15); one flint blade with an oblique distal truncation (CAT 23; illus 15); one denticulated quartz flake (CAT 28); and one pitchstone blade with sporadic edge-retouch (CAT 26; illus 15). Apparently, all flint and chert blanks and implements were detached by the application of hard percussion, whereas it was not possible to define how the pitchstone blade was detached, as it is a medial fragment. The quartz blanks were all detached by the application of bipolar technique.

The widths of the two blade-based implements (CAT 23 and 26) suggest middle or later Neolithic dates of origin. The quartz element of this sub-assemblage (ie less exclusive procurement), in conjunction with the presence of a typical denticulated piece, may indicate later prehistoric dates, as denticulated pieces are particularly common in Middle and Late Bronze Age contexts (Ballin 2002).

\subsection{Laigh Newton Central}

This sub-assemblage included twenty-two pieces, eighteen of which were debitage, with four being tools. The debitage consisted of two flint chips, four flint flakes, five quartz flakes, one chert flake, one possible agate flake, one flint blade, one pitchstone blade, and three indeterminate pieces in flint. The four tools comprised one discoidal knife on a flint flake (CAT 15; illus 15), one fragment of a polished flint implement (CAT 3; illus 15), one edge-retouched flint flake (CAT 8), and one edgeretouched chert flake (CAT 4). All definable tools, as well as most blanks in flint and chert, were detached by the application of hard-percussion; the quartz artefacts seem to have been manufactured in bipolar technique.

The widths of the flint blade and the pitchstone blade suggest a date in the middle to later part of the Neolithic period. The presence of six pieces (CAT 3, 13, 15, 16, 48 and 50) of probable Yorkshire flint (partly the dark homogeneous form, partly the lighter marbled form) indicates activities during the later Neolithic period. CAT 15 is a sophisticated, sub-triangular form of discoidal knife, with three slightly convex, acute edges. Its dorsal face was formed entirely by invasive retouch, whereas the ventral face displays invasive retouch along two of the three edges. In terms of outline, it corresponds to a polished 'discoidal' knife from Kempston, near Bedford, England (Evans 1897, fig. 256; Clark 1932, 41). Discoidal knives are generally perceived as a Late Neolithic form (Butler 2005, 170). 


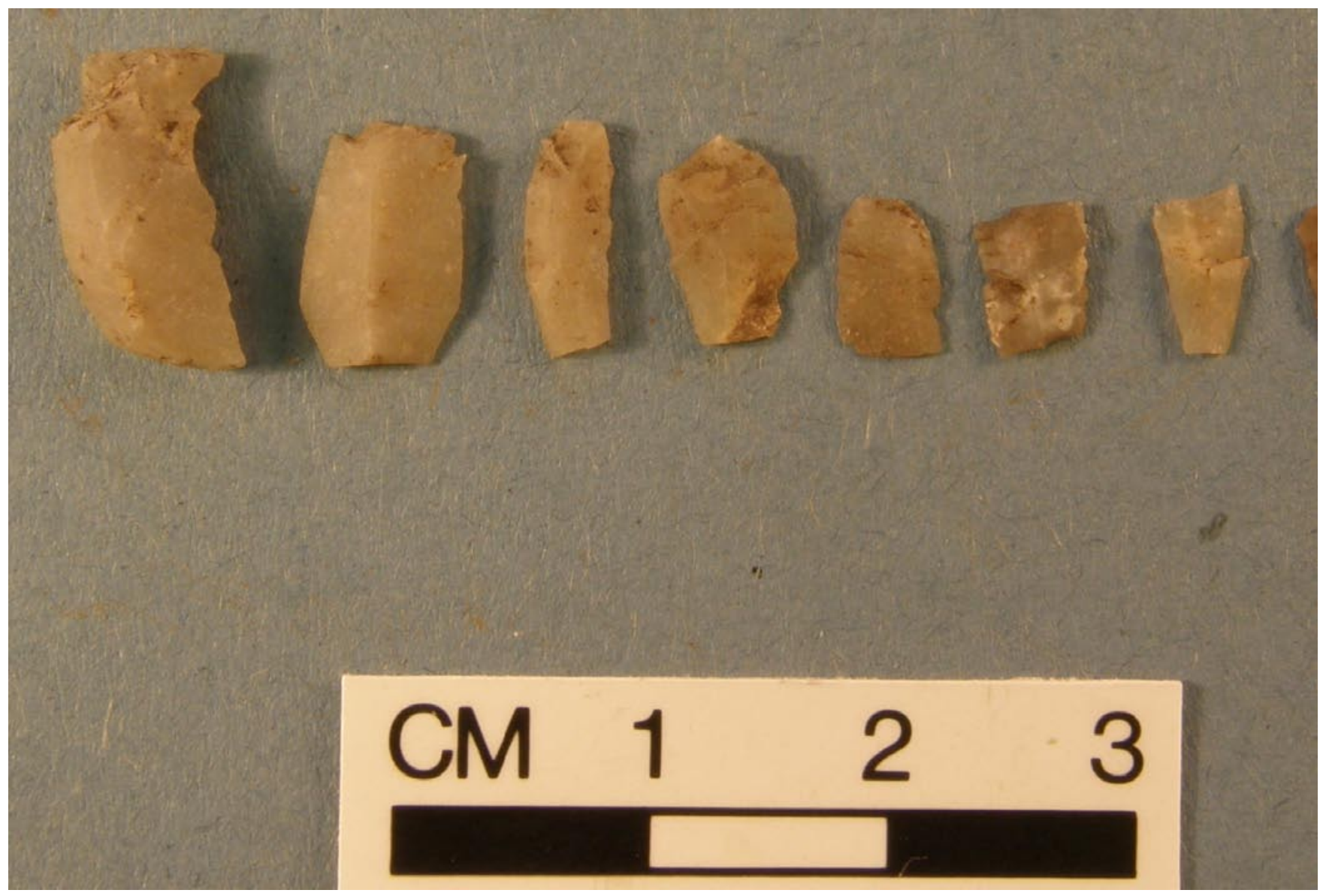

Illus 16 Microblade fragments from Laigh Newton East

\subsection{Laigh Newton East}

In contrast to the other three sub-assemblages, which appeared to be chronologically mixed, the lithic finds from the easternmost site seemed to represent a chronological unit, and they were most likely initially deposited at the same time and in connection with the same visit to the site. The twenty-one lithics were all in flint, with twelve pieces being chips and nine microblades or microblade fragments (illus 16), and were recovered from the fills (39005 and 39007) of two pits (39006 and 39008). All microblades were detached by soft percussion, and they were generally fairly narrow and thin. Only CAT 71 was intact, probably because it is a fraction thicker and more robust than the other microblades.
The dimensions of the microblades indicate a date either in the Late Mesolithic period or in the earliest part of the Early Neolithic, and the flint is local, as would be expected from an early assemblage.

\subsection{Discussion of the lithic assemblage}

The lithic assemblage from Laigh Newton was composed of four main sub-assemblages, and all but that from the easternmost site were chronologically mixed (see table 4). The finds from the eastern site most likely represent a Late Mesolithic or very early Early Neolithic microblade industry, and the artefacts were probably deposited in connection with a brief visit to the location. If all artefacts left during this visit were recovered, the small assem-

Table 4 Dates of the activities at Laigh Newton, as suggested by diagnostic lithic elements

\begin{tabular}{lclccc}
\hline & $\begin{array}{l}\text { Late Mesolithic/ } \\
\text { Early Neolithic }\end{array}$ & $\begin{array}{l}\text { Early } \\
\text { Neolithic }\end{array}$ & $\begin{array}{l}\text { Late } \\
\text { Neolithic }\end{array}$ & $\begin{array}{l}\text { Early } \\
\text { Bronze Age }\end{array}$ & $\begin{array}{l}\text { Later } \\
\text { prehistory }\end{array}$ \\
\hline $\begin{array}{l}\text { Laigh Newton West } \\
\text { Laigh Newton North-west }\end{array}$ & $?$ & & \\
Laigh Newton Central & & & & \\
Laigh Newton East & & & & \\
\hline
\end{tabular}


blage may represent the activities of Late Mesolithic (full-time) hunters or Early Neolithic (part-time) hunters. If the finds are the truncated remains of a larger assemblage, it may represent a more substantial Mesolithic camp or a Neolithic residential settlement.

The other three sub-assemblages all included Early Neolithic material, as represented by the three pitchstone objects (Ballin 2009), but they were also characterised by a noticeable Late Neolithic element. The Late Neolithic finds included broad hard-hammer blades, though none was detached by the application of the so-called Levallois-like technique (Ballin forthcoming a), a sub-triangular discoidal knife, and a number of chips and flakes in Yorkshire flint. Although the exchange in Yorkshire flint may have been initiated in the later part of the Early Neolithic period, and probably continued into the Early Bronze Age, in Scotland this raw material is mainly associated with the Late Neolithic period (Ballin forthcoming b). The quartz finds from Laigh Newton Central, not least the denticulated piece, may date to the later part of Scottish prehistory. 


\section{CARBONISED PLANT REMAINS, by Susan Ramsay}

\subsection{Laigh Newton West}

\subsubsection{Structure A (Appendix 7)}

The charcoal assemblages from the features of Structure A were generally mixed, with alder, birch, hazel, oak and willow all present. There was no evidence for any of the remains being posts burnt in situ, ie a post-hole with a charcoal assemblage almost exclusively of one type. Many of the post-hole fills also contained fragments of hazel nutshell.

Linear hollow 005 and post-hole 154 contained charcoal assemblages dominated by alder and birch, with lesser amounts of hazel. Notably, oak was absent from the fills of both of these internal features. In addition, these features contained significant numbers of carbonised cereal grain, mainly identifiable as oats. Several of the post-holes and pits forming the outline of Structure A also contained traces of oat grains.

Aligned parallel to the north-east of the structure were a further series of post-holes and stake-holes, only one of which (032) contained significant quantities of charcoal, comprising a mixed assemblage of alder, birch, hazel and hazel nutshell.

\subsubsection{Structure B (Appendix 8)}

The carbonised remains recovered from Structure B, in the south-east corner of Laigh Newton West, were not abundant and many of the post-holes $(054,046$, 044, 053 and 301) produced no carbonised remains. Other post-holes (167, 050, 051, 048 and 049) contained only trace amounts of charcoal, with alder, hazel, oak, willow and heather represented in all and hazel nutshell recorded in two of the post-holes (049 and 050). Post-hole 052 contained the greatest amount of charcoal, comprising alder and birch, although not a particularly significant amount.

\subsubsection{Structure C (Appendix 9)}

The large pit 099 was filled with angular stones and soil but produced no carbonised remains. Of the arc of post-holes apparent on the north side of pit 099, nine were analysed for the presence of carbonised remains $(080,081,082,083,084,085,086,087$ and 093). Oak was the only charcoal type in post-holes 080 and 081 , and the dominant type in post-holes 083 and 087, though only in small amounts. Small amounts of alder, hazel and willow charcoal were also recorded from the fills of this arc of post-holes, together with occasional cereal grains, tentatively identified as oats, and traces of hazel nutshell. An earlier pit (133) had been cut by some of these post-holes but no carbonised material was recovered from this feature.

Five further post-holes were located between pit 099 and the arc of post-holes. Four of these were analysed for the presence of carbonised remains (090, 091, 092 and 122). Of these, only one (090) produced any carbonised remains, with traces of alder, birch and hazel charcoal with fragments of hazel nutshell.

\subsubsection{Structure D (Appendix 10)}

The primary fill (116) and the upper fill (114) of pit 040 contained significant amounts of charcoal, with hazel, alder, oak and birch all present, whilst there was significantly less charcoal in the middle fill (115), which contained only small amounts of birch and hazel. The upper and middle fills also contained traces of hazel nutshell and a single carbonised raspberry/bramble pip was also recovered from the middle fill.

Of the segmented linear feature to the north of pit 040, only fill 139 from linear feature 126 contained any carbonised remains, and these consisted merely of traces of alder and oak charcoal.

Post-holes 034 and 035 contained traces of alder and birch charcoal. A single carbonised bramble/ raspberry pip was identified in post-hole 035, whilst post-hole 034 contained a single fragment of hazel nutshell. Four of the post-holes (038, 039, 183 and 193) from the arc to the east and south of pit 040 were analysed for the presence of carbonised remains. However, the fills produced no significant carbonised remains, with only a single fragment of hazel nutshell recovered from post-hole 038. Only traces of charcoal were recovered from the postholes $(041,042,185$ and 186) to the south of pit 040, with alder, oak and willow represented. Post-hole 042 also contained hazel nutshell and two cereal grains identified as barley and possibly oat.

\subsubsection{Western cluster of pits (Appendix 11)}

Both lower fills (277 and 278) of pit 250 produced significant quantities of charcoal, with alder, birch, hazel, oak and willow all represented. The upper fill (258) also contained significant quantities of charcoal, with alder, birch and hazel represented. Of the six pits located in the vicinity of pit 250 , five were analysed for the presence of carbonised remains. Pit 062 contained no carbonised remains, whilst pit 251 contained only traces of charcoal. Pits 059, 060 and 061 all contained carbonised remains, with oak as the dominant type, although traces of birch, willow and hazel nutshell were also recorded. These were the only pits in this grouping that had oak as the dominant type. 


\subsubsection{Miscellaneous features (Appendix 12)}

Of the pits and post-holes to the north of the linear segmented feature, pits 204, 270, 174 and treethrow hole 095 were analysed. Fill 079 from pit 174 contained a mixed charcoal assemblage of birch, heather type and oak, together with an indeterminate cereal grain. Tree-throw hole 095 contained a mixed assemblage of oak, hazel, willow and birch charcoal with a single fragment of hazel nutshell. From pit 204, only fills 199 and 200 produced any carbonised remains, but these were not abundant, with only traces of alder charcoal and hazel nutshell present, whilst the fill (173) of pit 270 produced no carbonised remains. Examination of features 073, 075, 078, 150, 148, 147, 141, 143, 162 and 145 produced little in the way of carbonised remains. Only features 150, 147 and 148 contained any carbonised remains, though only trace amounts of mixed charcoal and hazel nutshell.

Slightly towards the east lay another circular pit 61004 (filled by 61003), which was excavated during the 2005 evaluation and showed evidence for in situ burning. The charcoal assemblage was dominated by hazel, with alder, birch and oak present in lesser amounts. Of particular note were a significant number of carbonised cereal grains. Although almost $70 \%$ of the grain recovered was not identifiable to type, the remaining $30 \%$ was barley, some identifiable as six-row barley.

Pit 230 contained fire-reddened gravel, but produced only a single fragment of alder charcoal, suggesting that relatively insignificant burning occurred here. Another similar feature (226) again showed fire-reddening on its base, its fills (266 and 267 ) in this case containing significant amounts of carbonised remains, with charcoal of alder, hazel and oak, together with numerous carbonised cereal grains. Although the majority of the cereals were too poorly preserved to be identifiable to type, many were identifiable as six-row barley and some to the naked variety of this type. Fill 263 from elongated pit 229 produced alder charcoal with traces of oak.

Of the three small features to the west $(252,253$ and 254), only post-holes 252 and 254 produced any carbonised remains, with traces of hazel nutshell present. A couple of features to the south of the excavation area were also analysed (232 and 233). However, only pit 232 produced any carbonised remains, with only small traces of alder and oak charcoal.

\subsection{Laigh Newton Central}

\subsubsection{Structure E and associated features (Appendix 13)}

Seventeen samples were taken from various slots cut through the fill (052) of the shallow rectilinear groove (051) to the north-east of this excavation site. A mixed charcoal assemblage of birch, hazel, oak and willow was identified, along with a couple of possible oat grains and a single fragment of hazel nutshell. The fill (283) of a stake-hole (282) near the centre of the northern gully contained no carbonised remains.

To the east of the rectilinear structure lay a small circular pit (308), which produced only small quantities of birch and hazel charcoal. However, a large rectangular pit (063) to the south-west, contained large quantities of charcoal, mainly birch with lesser amounts of alder. Significant quantities of carbonised bark were also identified. The charcoal had come from large pieces of roundwood, and during excavation it was noted that this roundwood seemed to have been laid as bundles in a north-west/southeast orientation. Some of the charcoal fragments had diagonally cut, rather than broken ends and there was evidence of burning having occurred in situ. The upper fragments of roundwood showed incomplete combustion, suggesting more than one episode of burning.

\subsubsection{Pit clusters (Appendix 14)}

The fills (218, 222, 228 and 230) of pits 217, 221, 227 and 229 were similar in terms of their carbonised assemblages, composed of alder, birch, hazel, oak and willow, along with a few fragments of hazel nutshell. However, the fill (214) of the outlying pit (213) of this group contained only hazel charcoal along with hazel nutshell fragments.

The fill (298) of one of these pits (297) to the south-west of this cluster of pits contained large quantities of hazel charcoal with traces of rowan, oak and willow, together with over 600 fragments of hazel nutshell. The fill (296) of another pit (295) also contained large quantities of hazel charcoal, with the only other charcoal present being a single fragment of willow. Again, over 400 fragments of hazel nutshell were also identified. The fill (294) of the third pit (293) had a carbonised assemblage dominated by hazel charcoal, with traces of alder, rowan type, oak and willow also present, together with over 200 fragments of hazel nutshell. These three pits contained very similar carbonised assemblages, dominated by hazel charcoal and hazel nutshell fragments.

\subsubsection{Miscellaneous pits and post-holes (Appendix 15)}

A number of smaller pits and post-holes within the north-west part of the excavation area were analysed for the presence of carbonised remains, although all proved to be barren apart from feature 211 , which contained large quantities of hazel and oak charcoal, with lesser amounts of birch and willow. There were also more than 600 fragments of hazel nutshell present. This assemblage was similar to those recorded from the pits to the south (293, 295 and 297). 
To the south-east of the rectilinear structure was pit 303, which contained large amounts of hazel and alder charcoal with some oak and hazel nutshell. Pit 029 also lay to the south-east of the rectilinear structure, but stood out as having a contrasting carbonised assemblage to the other pits within this area. The charcoal consisted of alder and birch but cereal grains were also present above trace level. Although a significant number of the grains were indeterminate due to poor preservation, the remainder were all identified as barley, with six-row hulled barley certainly present.

Analysis revealed carbonised remains within only some of the other features distributed randomly across the excavation area (001, 017, 025, 029, 033, $117,119,139,275,285,289,291,301$ and 305). These frequently contained similar mixed charcoal assemblages of alder, birch, hazel and oak, with occasional willow. Hazel nutshell was also commonly present.

\subsection{Laigh Newton East (Appendix 16)}

The fills (39005 and 39007) of the two pits (39006 and 39008) within this excavation area were similar, containing significant quantities of oak and hazel charcoal with lesser amounts of birch. More notably, significant numbers of carbonised cereal grains were also recorded and these were primarily emmer wheat with lesser numbers of possible bread wheat. Chaff from emmer wheat was also present, together with occasional carbonised weed seeds, and a large number of hazel nutshell fragments within pit 39006

\subsection{Discussion of carbonised plant remains}

\subsubsection{Laigh Newton West}

Radiocarbon dates of 4350-4220 cal BC (SUERC22443), 3360-3080 cal BC (SUERC-22444), 3360-3090 cal BC (SUERC-24620) and cal AD 10301220 (SUERC-24624) were recovered from four separate post-holes that defined Structure A (table 5). The lattermost radiocarbon date very likely derives from contamination from linear feature 005, which provided a similar radiocarbon date of cal AD 1020-1190 (SUERC-22167) and, along with post-hole 154, contained significant numbers of oat grains, which had evidently contaminated those closest features to linear hollow 005, probably by plough action. Excluding the evidence of medieval contamination, Structure A is therefore likely to be Neolithic in date. The carbonised remains from Structure A were very different, however, from those recorded in Neolithic timber rectilinear structures at Balbridie (Fairweather \& Ralston 1993), Claish (Barclay et al 2002), Balfarg (Barclay \& RussellWhite 1993) and Eweford (MacGregor \& Stuart 2007). These structures, unlike Structure A at Laigh Newton West, showed extensive use of oak in the construction process, were associated with finds of significant quantities of grain (barley or wheat) but showed little evidence for general domestic occupation debris. These structures also appeared, again unlike Structure A, to have been destroyed by fire, with post-holes containing the carbonised remains of oak posts and wattlework. In general, the features that formed Structure A contained very similar mixed charcoal assemblages of alder, birch, hazel, oak and willow, with some hazel nutshell fragments, and were just like those that would be expected from domestic hearth waste during the Neolithic. There was no evidence for the preferential collection of any particular wood type for fuel. There was also no evidence for burnt turf or heather, which might have suggested potential roofing material for the structure. However, as there were no significant spatial differences in the charcoal assemblage, it was not possible to identify any activities that may have taken place within the structure.

Structure B yielded radiocarbon dates of 520-370 cal BC (SUERC-22405), 2850-2470 cal вC (SUERC24625) and 2460-2140 cal BC (SUERC-24626) from three of its post-holes. The carbonised plant remains provided little further evidence for the use of this structure, though the mixed charcoal was more indicative of domestic hearth waste than structural debris.

No carbonised remains were recorded from pit 099, the central feature of Structure C, indicating that had any timber post been set here, it had been removed or left to rot and had not been burnt in situ. A standing stone, it might also be observed, would have left a pit devoid of charcoal too. Oak was the dominant type in several of the associated arc of stake-holes, suggesting perhaps that an oak-built palisade or fence bounded the pit on one side, though the quantities of charcoal involved were not large. Hazel and willow charcoal were also recorded from the post-holes, but the quantities were not sufficient to say that the oak palisade also supported wattlework panels. Mixed charcoal assemblages with hazel nutshell and occasional cereal grains, suggests that some domestic occupation occurred nearby. Carbonised willow from two of the post-holes yielded radiocarbon dates of 3640-3490 cal BC (SUERC22409) and 3500-3330 cal BC (SUERC-22410).

The centre of Structure D, pit 040, was interpreted in the field as a fire-pit due to the large quantities of charcoal it contained, and analysis of the carbonised assemblage supports this interpretation. The charcoal was consistent with domestic hearth waste, with the presence of hazel nutshell and a raspberry/bramble pip indicating that food was probably being prepared or eaten in the immediate vicinity. Similar food remains from post-holes 034 035 and 038 are suggestive of scatter from fire-pit 040. It was suggested during the field excavation that the position of this pit, on the highest point of the terrace, might imply a ritual function but there are no unusual charcoal types or food plant remains contained within the carbonised assemblage that 
Table 5 Radiocarbon dates

\begin{tabular}{|c|c|c|c|c|c|c|c|}
\hline Lab code & Context & Feature & $\begin{array}{l}\text { Single- } \\
\text { entity } \\
\text { species } \\
\text { (charcoal) }\end{array}$ & Years BP & $\begin{array}{l}\delta^{13} \mathbf{C} \\
(\% o)\end{array}$ & $\begin{array}{l}\text { Calibrated } \\
\text { 1-sigma } \\
\text { (years) }\end{array}$ & $\begin{array}{l}\text { Calibrated } \\
\text { 2-sigma } \\
\text { (years) }\end{array}$ \\
\hline & & Laigh Newton West & & & & & \\
\hline SUERC-22443 & 179 & Structure A post-hole 176 fill & Corylus & $5405 \pm 35$ & -25.6 & $4330-4240$ вс & $4350-4220$ вс \\
\hline SUERC-22444 & 209 & Structure A post-hole 208 fill & Corylus & $4500 \pm 35$ & -27.6 & $3340-3100$ вс & $3360-3080$ вс \\
\hline SUERC-24620 & 128 & Structure A post-hole 004 fill & Corylus & $4515 \pm 35$ & -25.7 & $3350-3110$ вс & $3360-3090$ вс \\
\hline SUERC-24624 & 257 & Structure A post-hole 248 fill & Corylus & $895 \pm 35$ & -27.2 & $\mathrm{AD} 1040-1210$ & AD $1030-1220$ \\
\hline SUERC-22167 & 153 & Linear feature 005 fill & Alnus & $920 \pm 30$ & -29.3 & AD 1040-1160 & AD $1020-1190$ \\
\hline SUERC-22405 & 284 & Structure B post-hole 048 fill & Alnus & $2345 \pm 30$ & -26.8 & $415-380$ вс & $520-370$ вс \\
\hline SUERC-24625 & 180 & Structure B post-hole 050 fill & Corylus & $4055 \pm 35$ & -24.5 & $2830-2490$ вС & $2850-2470$ вс \\
\hline SUERC-24626 & 299 & Structure B post-hole 052 fill & Betula & $3825 \pm 35$ & -25.8 & $2340-2200$ вс & $2460-2140$ вС \\
\hline SUERC-22409 & 009 & Structure C post-hole 082 fill & Salix & $4745 \pm 35$ & -24.2 & $3640-3550$ вс & $3640-3490$ вс \\
\hline SUERC-22410 & 014 & Structure C post-hole 087 fill & Salix & $4600 \pm 30$ & -26.5 & $3500-3350$ вс & $3500-3330$ вс \\
\hline SUERC-22168 & 116 & $\begin{array}{l}\text { Structure D pit } 040 \text { primary } \\
\text { fill }\end{array}$ & Alnus & $3875 \pm 30$ & -27.8 & $2460-2290$ вс & $2470-2280$ вС \\
\hline SUERC-22414 & 114 & Structure D pit 040 upper fill & Alnus & $3750 \pm 35$ & -24.4 & $2210-2050$ вс & $2290-2030$ вс \\
\hline SUERC-24628 & 160 & Structure D post-hole 034 fill & $\begin{array}{l}\text { Corylus } \\
\text { avellana }\end{array}$ & $5380 \pm 35$ & -25.8 & $4330-4170$ вс & $4340-4060$ вс \\
\hline SUERC-24627 & 218 & Structure D post-hole 042 fill & Alnus & $905 \pm 35$ & -26.7 & AD 1040-1180 & $\mathrm{AD} 1030-1210$ \\
\hline SUERC-22413 & 139 & Linear feature 126 fill & Alnus & $980 \pm 30$ & -26.5 & $\mathrm{AD} 1010-1150$ & AD 990-1160 \\
\hline SUERC-22411 & 278 & Pit 250 primary fill & Corylus & $3880 \pm 35$ & -28.1 & $2460-2300$ вс & $2470-2270$ вс \\
\hline SUERC-22412 & 307 & Pit 060 fill & Salix & $7450 \pm 30$ & -24.6 & $6380-6250$ вс & $6400-6240$ вс \\
\hline \multirow[t]{2}{*}{ SUERC-22433 } & 61003 & Fire-pit 61004 fill & $\begin{array}{l}\text { Hordeum } \\
\text { vulgare }\end{array}$ & $3310 \pm 35$ & -25.2 & $1625-1525$ вс & $1690-1500$ вС \\
\hline & & Laigh Newton North-west & & & & & \\
\hline SUERC-22419 & 288 & Occupation layer 288 & Corylus & $3455 \pm 30$ & -25.4 & $1880-1730$ вс & $1880-1690$ вс \\
\hline SUERC-22421 & 285 & Layer 285 & Alnus & $2960 \pm 35$ & -28.1 & $1260-1120$ вс & $1310-1050$ вс \\
\hline SUERC-22422 & 273 & Layer 273 & Corylus & $3460 \pm 30$ & -27.5 & $1880-1730$ вс & $1890-1690$ вс \\
\hline SUERC-22424 & 422 & Outer ditch 037 fill & Salix & $4825 \pm 30$ & -26.6 & $3660-3530$ вс & $3660-3520$ вс \\
\hline SUERC-22429 & 418 & Inner ditch 002 fill & Corylus & $2800 \pm 30$ & -23.7 & $995-910$ вс & $1040-890$ вС \\
\hline \multirow[t]{2}{*}{ SUERC-22430 } & 361 & Ditch 041 fill & Alnus & $2305 \pm 30$ & -26.7 & $405-365$ вс & $410-350$ вс \\
\hline & & Laigh Newton Central & & & & & \\
\hline SUERC-22434 & 052 & Rectilinear groove 051 fill & Betula & $1725 \pm 30$ & -25.0 & $\mathrm{AD} 250-350$ & AD $240-400$ \\
\hline SUERC-24629 & 052 & Rectilinear groove 051 fill & Betula & $2250 \pm 35$ & -24.3 & $390-230$ вс & $400-200$ вС \\
\hline SUERC-24630 & 052 & Rectilinear groove 051 fill & Corylus & $890 \pm 35$ & -24.9 & $\mathrm{AD} 1040-1210$ & $\mathrm{AD} 1030-1220$ \\
\hline SUERC-22435 & 270 & Pit 063 fill & $\begin{array}{l}\text { Alnus } \\
\text { roundwood }\end{array}$ & $1620 \pm 30$ & -27.1 & $\mathrm{AD} 390-540$ & $\mathrm{AD} 380-540$ \\
\hline SUERC-22439 & 230 & Pit 229 fill & Betula & $3880 \pm 30$ & -25.1 & $2460-2300$ вс & $2470-2280$ вс \\
\hline SUERC-22440 & 030 & Pit 029 fill & $\begin{array}{l}\text { Hordeum v } \\
\text { var vulgare }\end{array}$ & $2215 \pm 30$ & -22.0 & $320-200$ вс & $380-200$ вС \\
\hline SUERC-22441 & 296 & Pit 295 fill & $\begin{array}{l}\text { Corylus } \\
\text { avellana }\end{array}$ & $4785 \pm 35$ & -24.4 & $3590-3510$ вс & $3650-3510$ вс \\
\hline \multirow[t]{2}{*}{ SUERC-22442 } & $\begin{array}{l}11004 \\
(=298)\end{array}$ & $\begin{array}{l}\text { Pit } 11006 \text { fill } \\
(=297)\end{array}$ & $\begin{array}{l}\text { Corylus } \\
\text { avellana }\end{array}$ & $4745 \pm 35$ & -24.5 & $3640-3380$ вс & $3640-3490$ вс \\
\hline & & Laigh Newton East & & & & & \\
\hline SUERC-22432 & 39007 & Pit 2028-39008 fill & $\begin{array}{l}\text { Triticum } \\
\text { dicoccum }\end{array}$ & $4910 \pm 35$ & -23.9 & $3710-3650$ вс & $3770-3640$ вс \\
\hline
\end{tabular}


might confirm this hypothesis. Radiocarbon dates from the primary and tertiary fills of fire-pit 040 were 2470-2280 cal BC (SUERC-22168) and 22902030 cal BC (SUERC-22414) respectively. The segmented linear feature to the north of the firepit and post-hole 042 to the south, while yielding generally similar carbonised remains to the firepit, provided radiocarbon dates of cal AD 990-1160 (SUERC-22413) and AD 1030-1210 (SUERC-24627) respectively, thereby indicating that these were probably not contemporaneous with the fire-pit or the ring of post-holes around it, one of which (034) yielded a radiocarbon date of $4340-4060$ cal BC (SUERC-24628).

The largest of the pits (250) excavated in the north-west corner of the area contained significant quantities of charcoal, the primary fill providing a radiocarbon date of 2470-2270 cal BC (SUERC22411). The charcoal assemblage was consistent with domestic hearth waste and provided no indication that this feature was ever a post-hole. The remaining pits within this cluster produced small quantities of charcoal, with oak dominating in three of the assemblages. Though this might suggest oak posts burnt in situ, the quantities of charcoal involved were small and a radiocarbon date of 6400-6240 cal BC (SUERC-22412) was produced from one of these pits (060). The limited quantities of charcoal recovered would suggest that if these did indeed hold any structure, this was not destroyed by fire. There was a suggestion during the field excavation that this cluster of pits might have been evidence for deliberate planting of trees for a ritual purpose. However, it was not possible to determine this through excavation and there is no definitive evidence for this practice having occurred anywhere in Scottish prehistory.

A large number of apparently unrelated pits, postholes and other features were scattered across the Laigh Newton West excavation area. In general, these contained mixed charcoal assemblages with occasional fragments of nutshell. This suggests that there was significant occupation in the vicinity which resulted in the scatter of general domestic hearth waste over much of this area. Even for features such as tree-throw 095, the mixed charcoal assemblage it contained was consistent not with the burning of the tree that created this feature, but with the deposition of hearth waste. Possible evidence for the processing of grain, however, was recorded in several of the scattered features. Pit 61004 contained significant numbers of carbonised cereal grains along with a mixed charcoal assemblage. The presence of barley, and no other cereal type, might by itself suggest a later prehistoric date for this feature, which was confirmed by a radiocarbon date from one cereal grain of 1690-1500 cal BC (SUERC-22433). Pit 226 contained a similar assemblage, but with some cereals further identifiable to naked six-row barley. This might narrow down the possible age of this particular feature to the Neolithic, as naked barley was most commonly grown during the Neolithic period in Scotland and is rarely seen in sites of later date (Dickson \& Dickson 2000). The presence of in situ burning, charcoal and grain suggests that small-scale cereal processing, possibly parching prior to grinding, was being undertaken in this area and that some of the grain was accidentally charred.

A number of single entity charcoal fragments from Laigh Newton North-west, located downslope from Laigh Newton West, yielded radiocarbon dates ranging from the Neolithic (3660-3520 cal BC (SUERC-22424)) through the Bronze Age (1880-1690 cal BC (SUERC-22419); 1310-1050 cal вC (SUERC22421); 1890-1690 cal BC (SUERC-22422); 1040-890 cal BC (SUERC-22429)) to the Iron Age (410-350 cal вС (SUERC-22430)), which had probably been deposited here by plough action and soil movement downhill.

\subsubsection{Laigh Newton Central}

Structure E, defined by rectilinear gully 051, produced carbonised remains consistent with domestic hearth waste rather than structural debris, but from which a range of radiocarbon dates (cal AD 240-400 (SUERC-22434), 400-200 cal BC (SUERC-24629) and cal AD 1030-1220 (SUERC24630)) were obtained. The single stake-hole (283) apparent within the gully produced no charcoal and so provides no further evidence as to whether the gully once held a line of timber posts.

Of particular interest was a large rectangular pit (063) to the south-west of Structure E. Large quantities of charcoal were found within this pit and it was clear, during excavation, that bundles of branches had been placed in a north-west/south-east orientation and then been burnt in situ. The branches were less than $100 \mathrm{~mm}$ in diameter but predominantly intact roundwood, rather than split timbers. There was evidence for tool marks on the ends of some charcoal pieces, with the ends having been diagonally cut, rather than having broken ends. The charcoal was predominately birch with smaller quantities of alder, and bark was extremely common, indicating that the branches had not been stripped of bark prior to burning. The upper fragments of roundwood showed incomplete combustion, suggesting more than one episode of burning. Birch and, more especially, alder are known to have been coppiced for charcoal production and the presence of such a large proportion of similar-sized pieces of roundwood within this pit might lend weight to this as an explanation (Edlin 1973; Gale \& Cutler 2000). No evidence for food plant remains, such as hazel nutshell or cereal grain, was recorded from this feature. Considering the large quantities of charcoal present, if this had been a domestic hearth it might be expected that at least some carbonised food remains might have survived. The radiocarbon date of cal AD 380-540 (SUERC-22435) obtained from a fragment of alder charcoal lends weight to occupation of this site during the late Iron Age. 
Of the pit cluster to the west of the rectilinear structure, the group of large, sub-circular pits contained mixed charcoal assemblages and hazel nutshell fragments, similar to the general domestic hearth waste scatter that was seen over much of Laigh Newton West. A fragment of birch charcoal from one of these pits (229) yielded a radiocarbon date of 2470-2280 cal BC (SUERC-22439). The outlying pits of this cluster (297, 295 and 293) to the south-west, contained more distinctive carbonised assemblages dominated by hazel charcoal and very large numbers of hazel nutshell fragments, generally indicative of a Mesolithic or early Neolithic date (Mithen et al 2001). This was confirmed by the radiocarbon dates obtained from two of those pits, 3650-3510 cal вС (SUERC-22441) from pit 295 and 3640-3490 cal BC (SUERC-22442) from pit 297. This material was found in conjunction with pottery, burnt bone and flint, which suggests that these were rubbish pits. The fact that the charcoal assemblage was overwhelmingly made up of hazel could simply be that this species was easy to collect for fuel, though it is possible that there was a component of structural debris incorporated into this assemblage.

The large number of isolated scattered features excavated within this area generally contained carbonised assemblages of mixed charcoal and hazel nutshell, in keeping with the rest of the site and providing further evidence for the presence of prehistoric settlement in the immediate vicinity. Of particular note was pit 211, which produced a charcoal assemblage dominated by hazel and hundreds of hazel nutshell fragments, similar to the larger pits to the south-west (293, 295 and 297), suggesting that these pits were broadly contemporaneous. Only one pit (029) produced any significant evidence for arable agriculture in the form of carbonised cereal grain, mainly barley, although the quantities involved were small and not sufficient to indicate that cereal processing was occurring in this area. A radiocarbon date of 380-200 cal BC (SUERC22440) from one of these grains indicates occupation around the same time as that indicated further along the terrace at Laigh Newton West.

\subsubsection{Laigh Newton East}

The two pits (39006 and 39008) here yielded significant numbers of carbonised cereal grain, which was primarily emmer wheat, with some possible bread wheat. These were the only features at Laigh Newton with significant numbers of wheat grains present. Chaff and a few carbonised weed seeds were also present, suggestive of cereal processing waste. A radiocarbon date of 3770-3640 cal BC (SUERC22432) confirmed the likely Neolithic date for these deposits (Dickson \& Dickson 2000), which was also indicated by the significant numbers of carbonised hazel nutshell fragments present.

\subsubsection{General observations}

The excavations at Laigh Newton have provided evidence for occupation across this terrace over a prolonged period of prehistory. It is clear from the carbonised remains that during the earlier phases of occupation, the surrounding woodlands were probably still relatively undisturbed, providing a range of typical lowland woodland tree species for fuel and construction.

Although it appears that a Neolithic timber building may have existed at Laigh Newton West, the carbonised remains here are not comparable to similar timbered halls excavated in Scotland. Oak does not seem to have been the primary building material and there was no evidence for the hall having been destroyed by fire. It is also notable that there seemed to be significant amounts of domestic hearth waste over much of the area, whereas many Neolithic ritual structures are noticeably 'clean' of domestic waste.

The concentrations of hazel nutshell fragments in some of the pits may indicate a Mesolithic or early Neolithic date for these earliest occupation features. Evidence for Neolithic agriculture was found in the form of carbonised emmer and bread wheat, together with naked barley, all of which are characteristic of the Neolithic period in Lowland Scotland. Other carbonised barley grain also extends the period of occupation into the Bronze Age.

Evidence for the production of charcoal was present in Laigh Newton Central. This might suggest that there was industrial activity of some kind taking place on this site. The fact that birch and alder wood were being used instead of oak would suggest that this activity was probably later prehistoric or early historic in date, as much of the native oak woodland was cleared by this time. 


\section{DISCUSSION}

The prehistoric archaeological remains excavated at Laigh Newton had clearly been truncated by ploughing. The effect of this had not only removed any trace of occupation surfaces that may once have been present and ensured that only the bases of the deepest sub-surface features survived, but had also removed artefacts from their original context. This was not only demonstrated by the small quantity of prehistoric pottery and lithics recovered from the overlying topsoil on the western and central excavation sites, but the inclusion of residual prehistoric material in the north-west site, stratigraphically above medieval pottery (James forthcoming). Deposited here by topsoil creep and ploughing from their most likely origin upslope at Laigh Newton West, this material, which spanned the Neolithic to the Iron Age periods, clearly demonstrates the movement of some artefacts and environmental evidence from their original prehistoric context.

There was further good evidence for residual artefact distributions within many of the archaeological features. This is best exemplified by the evidence for Mesolithic occupation at Laigh Newton. A fragment of willow charcoal, from pit 060 within the western site, was radiocarbon dated to 6400-6240 cal BC (SUERC-22412), but the pit also contained prehistoric pottery of indeterminate date and was part of an arrangement of pits that included another that yielded substantial evidence for Late Neolithic and Early Bronze Age deposition. A Late Mesolithic/Early Neolithic assemblage of lithics, in fact the only chronologically coherent lithic assemblage from Laigh Newton (see Ballin above), was recovered from two pits within the eastern excavation site. Early Neolithic pottery sherds were also recovered from the same pits (see Ballin Smith above), as well as a radiocarbon date of $3770-3640$ cal BC (SUERC-22432) from one of many carbonised grains of emmer wheat present (see Ramsay above). However, even this Neolithic material was residual, as medieval pottery was also recovered from the single fill deposits within these two pits (see Somerville above) and which provides the only reliable terminus post quem for the date of the pits (Barker 1993, 224). Therefore, while there was residual Mesolithic activity evident at Laigh Newton, no specific features could be dated with certainty to the Mesolithic period.

Notwithstanding these constraints and that plough truncation had removed almost all evidence for stratigraphic relationships between individual features, it was nevertheless possible to recognise, amongst the wide scatter of features across the western and central excavation sites at Laigh
Newton, discrete coherent clusters of features associated with corresponding concentrations of artefacts and environmental evidence that can tentatively be tied into specific chronological episodes of occupation (illus 17 and 18).

One of the most coherent clusters of features on the western site was Structure A, defined by five pairs of matching post-holes outlining a rectilinear, NW/ SE-aligned structure. Possibly associated with this structure was a parallel line of smaller post-holes and stake-holes to the $\mathrm{NE}$ and a single post-hole to the SW. While no artefacts were found within any of these post-holes, and only minute amounts of burnt bone considered too insignificant in quantity for analysis, there were consistently mixed charcoal assemblages of alder, birch, hazel, oak and willow, with some hazel nutshell fragments from almost all the features (see Ramsay above). The range of radiocarbon dates recovered from three separate post-holes in this structure, 4350-4220 cal BC (SUERC-22443) to 3360-3080 cal BC (SUERC-22444) and 3360-3090 cal BC (SUERC-24620), clearly indicate occupation during the Neolithic, though given the improbably long duration suggested by these dates, may indicate the incorporation of residual charcoal from an earlier Neolithic occupation of the site. There were no contemporary internal features evident within this structure, as the linear feature that cut one of Structure A's post-holes yielded a radiocarbon date of cal AD 1020-1190 (SUERC-22167) and a significant number of oat grains, not present in domesticated form in Neolithic Scotland in any case. The latter feature was itself cut by another posthole, which also contained oat grains, and together with another linear feature to the north, which provided a similar date of cal AD 990-1160 (SUERC22413), clearly demonstrates medieval activity here, probably related to the farmstead to the north (see James forthcoming). The presence of single oat grains in those post-holes of Structure A closest to these medieval features suggests a degree of contamination, confirmed by the radiocarbon date of cal AD 1030-1220 (SUERC-24624) from one of Structure A's post-holes, and which together with the residual charcoal debris from the early Neolithic, clearly demonstrates that the case for a chronological coherency to Structure A is far from cut and dried, but the weight of evidence seems consistent with occupation at some point during the latter centuries of the fourth millennium BC.

The form and dimensions of Structure A certainly fall within the parameters of other Neolithic timber rectilinear structures across Scotland, Britain and NW Europe (Brophy 2006, 33; Darvill 1996, 86-87; Grogan 1996, 43; Barclay et al 2002, 129). While 


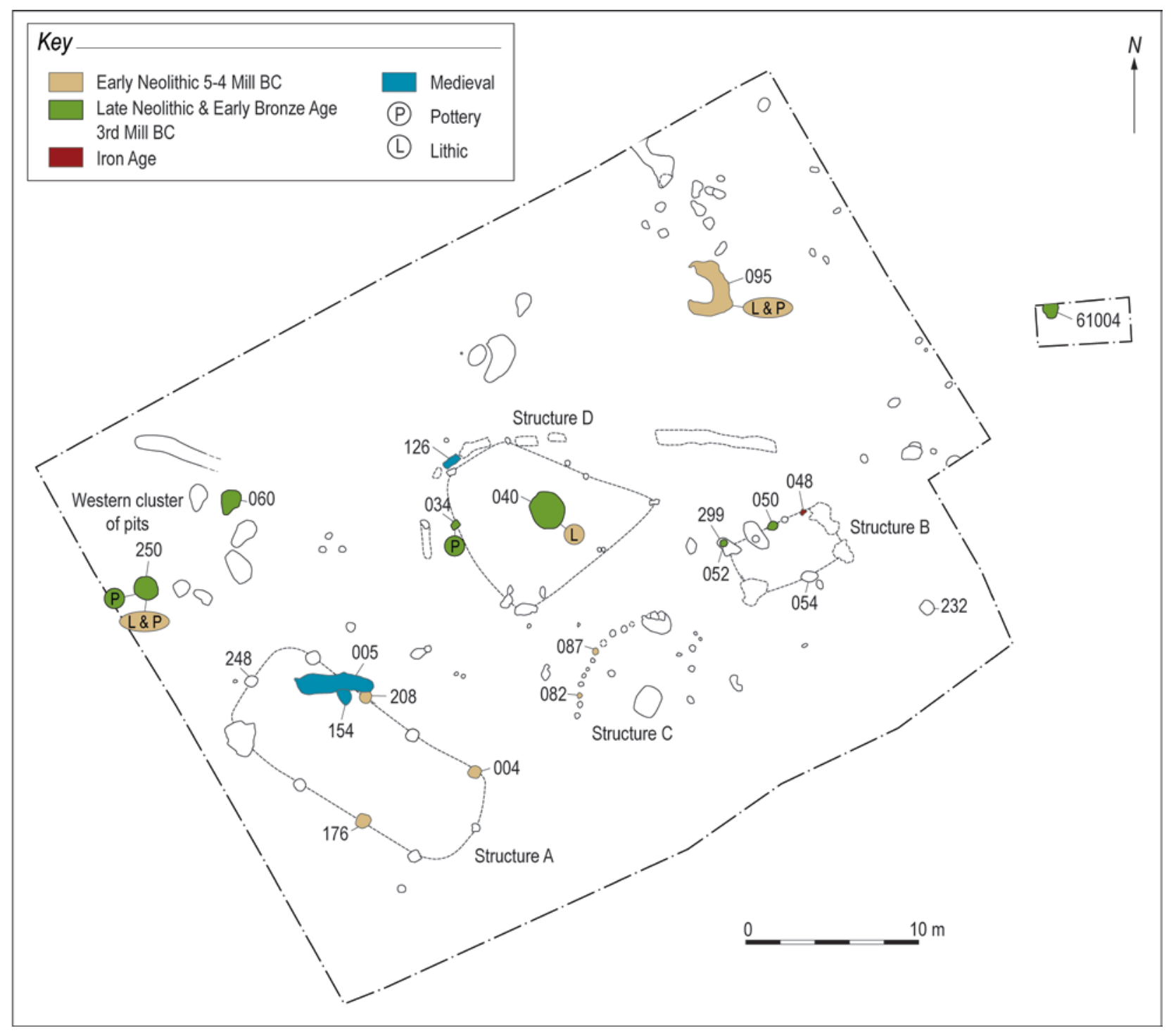

Illus 17 Laigh Newton West-dated features and finds distribution

many of those Scottish structures dated to the end of the fourth millennium $\mathrm{BC}$ have been interpreted as unroofed enclosures (Brophy 2006, 35-37), it seems likely that Structure A was a roofed building. The majority of the post-holes, where post-pipes were still evident, appeared to have held posts uniformly $c 0.30 \mathrm{~m}$ in diameter, sufficiently thick to form a load-bearing structure that might support a roof. The central space was only $6.2 \mathrm{~m}$ wide, and the spaces between each neighbouring post ranged between $2.3 \mathrm{~m}$ and $3.3 \mathrm{~m}$ apart, again sufficiently close to allow the matching pairs of posts to plausibly support a roof, given comparison with other probable roofed Neolithic buildings in Scotland (Hogg 2002, 112-113), though it should be noted that similar comparisons have not prevented interpretations of unroofed enclosures being made (Barclay et al 2002, 106-111). While single or multiple inner axial posts are apparent in some Neolithic structures, there seem no exact parallels apparent amongst excavated Neolithic houses in south-west Scotland (Kirby 2011,
6-7) or elsewhere in Britain and beyond (Darvill 1996, 86-87 and 94; Grogan 1996, 45; Malone 2001, 49; Barclay et al 2002, 101-130; Brophy 2006, 33; Murray et al 2009, 30) for the matching outer axial posts at either 'gable end' of Structure A. The closest parallels to Structure A seem to be Schwarzen Berg in Lower Saxony and Carsie Mains in Perth and Kinross (Barclay et al 2002,130). While the house at Schwarzen Berg was of very similar dimensions to Structure A, and had axial posts on its outer wall, it also had significant differences, such as inner axial posts, inner divisions and many more post-holes, especially at both terminal ends. The structure at Carsie Mains likewise was of similar dimensions and alignment, but again its axial terminals were defined by many more post-holes and its inner postholes were significantly smaller and therefore less credible as load-bearers than its outer wall postholes. Its excavators could not conclude whether it was a roofable structure (Brophy \& Barclay 2004, 19). However, it seems more plausible that the 


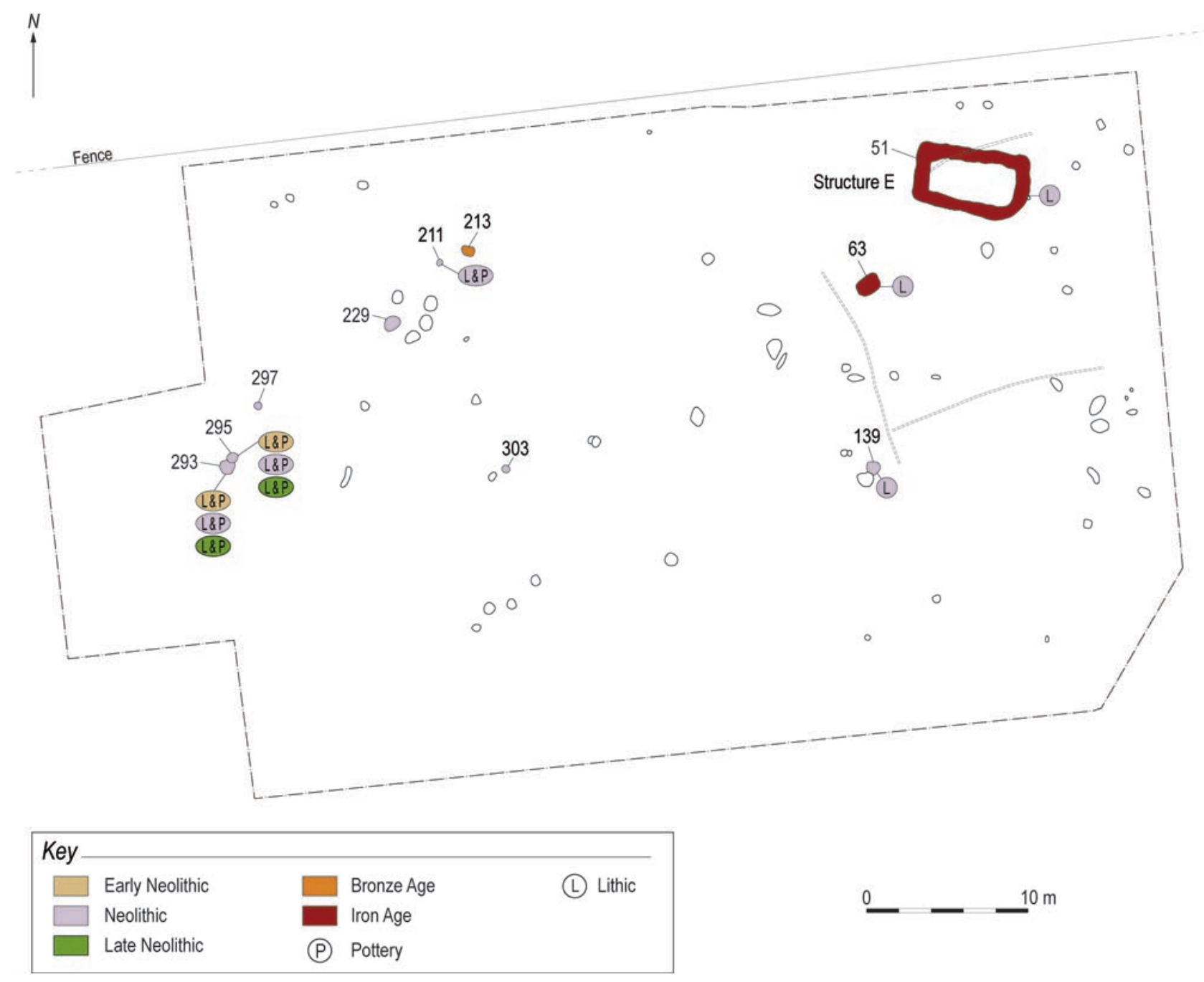

Illus 18 Laigh Newton Central-dated features and finds distribution

terminal axial posts at Laigh Newton supported not an enclosing fence but a central ridge roof beam. Furthermore, the parallel line of smaller post-holes and stake-holes corresponding to the post-holes forming the north-east line of Structure A and the single post-hole corresponding to the southernmost posthole may represent the only surviving elements of ties or external stays perhaps created to strengthen the stability of the structure (Hogg 2002, 113).

Structure A may therefore have comprised a three-aisled roofed building $15.1 \mathrm{~m}$ long and perhaps $12.8 \mathrm{~m}$ wide, somewhat shorter than the largest of the Neolithic timber halls in Scotland, but relative to its length wider than most other Neolithic buildings, and, covering a potential floor space of $193 \mathrm{~m}^{2}$, larger than most Neolithic buildings in Britain (Topping 1996, 159). Even if the outer aisles are excluded, the central space occupies $94 \mathrm{~m}^{2}$, which, excluding the abnormally large buildings at Balbridie and Claish, lies at the upper limit for Neolithic rectangular houses. While the paucity of artefacts and the lack of any significant spatial differences apparent in the distribution of charcoal offers little evidence as to how Structure A was occupied, the mixed nature of the charcoal assemblage might seem consistent with domestic occupation. As Ramsay has already noted (see above), the carbonised remains were very different from other Neolithic timber buildings in Scotland. There was no evidence to demonstrate that Structure A was built of oak. Barley or wheat grains were also not evident other than solely within the medieval features that overlay it and there was no evidence that it had been destroyed by fire. Given the number of post-pipes evident within the post-holes of Structure A, it is clearly apparent that the structural posts were allowed to decay naturally. In fact the only post-hole that showed signs of disturbance, other than that cut by the medieval linear feature, was the irregular post-hole at the north-west corner, the disturbance in this case probably caused by the displacement of packing stones through plough action. If the general mix of charcoal recovered from Structure A was incorporated into the post-holes during the life or immediate post-abandonment of the building, this might seem more consistent with general domestic occupation than perhaps the specialised role envisaged for many rectilinear timber halls in Scotland (Barclay et al 2002, 131-132; Noble 2006, 59 and 69; Brophy 2007, 92). Certainly the axial entrances at Balbridie and Claish and other Neolithic 
ritual enclosures such as Balfarg, are not possible at Laigh Newton, those spaces being occupied by the two axial posts supporting the roof ridge. Given the lack of any evidence for internal screens or an upper floor for storage, apparent also at Balbridie and Claish (Barclay et al 2002,104-106), it does not seem unreasonable to postulate a different nature of occupation for Structure A. While the absence of material culture within Structure A, similarly apparent in contemporary unroofed enclosures such as Balfarg, Littleour and Carsie Mains, might be to some suggestive of a ceremonial or ritual purpose (Barclay \& Russell-White 1993, 178-182; Brophy 2006, 36-37), this absence of artefacts may not only reflect the result of plough truncation but perhaps the deliberate deposition of artefacts elsewhere. Certainly the absence of material culture from many later prehistoric roundhouses is not accepted as evidence for an essentially non-domestic nature of occupation; rather, there is growing evidence that many of these roundhouses were regularly swept clean (Toolis 2007, 300). There seems no reason why this could not have been the case for many Neolithic dwellings too. Therefore, while this absence of evidence of course is not evidence of absence, and there are similarities, owing no doubt to a sharing of the same architectural 'vocabulary' (Barclay et al 2002,132 ), there also seem too many differences to permit the assumption that Structure A fulfilled a primarily ritual function similar to that suggested for many other contemporary rectilinear structures (Brophy 2007, 92; Thomas 2008, 79-80).

A few metres to the east of Structure A was another coherent pattern of features, Structure C, composed of a semi-circular arrangement of shallow stake-holes that defined a space $c 3 \mathrm{~m}$ wide around the north-west side of a large stone-packed pit. Radiocarbon dates of 3640-3490 cal BC (SUERC22409) and 3500-3330 cal BC (SUERC-22410) were obtained from willow charcoal fragments from two of the stake-holes, indicating that this structure may have been more or less contemporary with Structure A. There is some evidence to suggest that this arc of stake-holes formed an oak-built fence (see Ramsay above). Together with the single sherd of prehistoric pottery with carbonised food deposits, the occasional indeterminate carbonised cereal grain and hazel nutshell recovered from some of these stakeholes may indicate domestic occupation nearby but the presence too of three carbonised oat grains hints at contamination, probably from the same medieval activity recorded above Structure A. The pit itself was devoid of artefacts or charcoal, but was filled with large angular stones that were considered in the field to have slumped into a central post-hole. If a post or stone had been set into the fill of this pit, it seems that this had been subsequently removed, not left to rot or burn in situ. While this structure defies obvious explanation, which is perhaps why the excavators postulated a ritual function, the evidence from a very similar Late Neolithic structure at Kintore in Aberdeenshire was interpreted as a windbreak pro- tecting a working area (Cook \& Dunbar 2008, 314). While structured deposition of artefacts may have accompanied the filling of the pit at Kintore (ibid, 54-55), as may have occurred at another similar Late Neolithic structure at Lamb's Nursery in Midlothian (Cook 2000, 96-97), no such structure deposition was apparent at Structure C. The structured deposition at Kintore and Lamb's Nursery may only relate to the 'closing' of the structure, rather than its primary role, and if this function was more prosaic, it would adhere to the evidence recovered from the majority of the Irish Neolithic settlements, for instance, for various domestic activities undertaken not within houses but elsewhere within the surrounding habitation area (Grogan 1996, 57-59).

The idea of a single Neolithic building, Structure A, surrounded by a wider habitation area, to which Structure C might belong, seems to accord with the rest of the fourth millennium BC activity apparent at Laigh Newton. Carinated and Grooved Ware pottery sherds, some with encrusted carbonised food deposits, and pitchstone and flint blades belonging to the Early Neolithic period (see Ballin Smith and Ballin above) were recovered from the secondary fill of a pit to the north-east of Structure A, but given that an Early Bronze Age Beaker vessel sherd with a radiocarbon date of 2470-2270 cal вС (SUERC-22411) were recovered from the underlying primary fill of this pit, together with another Beaker vessel sherd from the same secondary fill, this material was clearly residual and demonstrates no more than a prior general domestic occupation of the surrounding ground during the Early Neolithic. The only feature to have contained a potentially chronologically consistent assemblage of pottery and lithics at Laigh Newton West was pit 095, near the north-east corner of the excavation area. Identifiable as a tree-throw by its characteristic banana shape, the deposition of early Neolithic artefacts within its upper fill, along with birch, hazel, oak and willow charcoal and carbonised hazelnut shells, could be perceived as the remnants of structured deposition, perhaps related to the notion of treethrows as markers or foci for camp-sites within a heavily wooded landscape (Evans et al 1999, 2429). The two rim sherds from a carinated vessel, for instance, could derive from the deliberate selection of only these parts of the vessel. The incompleteness of this pottery vessel might also, on the other hand, merely reflect the incomplete survival of this feature (Conolly \& MacSween 2003, 43). That the artefacts and bulk of the charcoal were only present in the secondary fill, the primary fill being largely clean of all but a very small amount of charcoal, suggests that deposition was not demonstrably deliberate but could equally well have accidentally accumulated within this hollow. The flint microblade might also be Late Mesolithic rather than early Neolithic (see Ballin above), and therefore indicative of residual material. Lastly, the limited number of artefacts and the abraded nature of the pottery sherds, by comparison with deposition patterns at other sites 
(Cook \& Dunbar 2008, 311; Pollard 1997, 85-7 and $111)$, imply that this is little more than accidentally accumulated domestic debris.

The diagnostically early Neolithic material recovered from several pits in the central excavation site at Laigh Newton likewise cannot be attributed to structured deposition, as Late Neolithic and Early Bronze Age material was also recovered from the same contexts. This evidence for residual domestic debris, again more or less contemporary with the occupation of Structure A, seems more consistent with the manuring of the surrounding land with midden material, perhaps as part of a system of intensive arable farming comparable with those recorded in Orkney (Guttmann et al 2004, 61), which is further supported by the evidence for the processing of barley in a pit to the east (see Ramsay above) and the significant quantity of residual emmer wheat, dated to 3770-3640 cal BC (SUERC22432), recovered from the pits at the Laigh Newton East excavation.

The evidence would therefore seem to indicate settlement at Laigh Newton from around the middle of the fourth millennium BC, related to arable agriculture and focused perhaps around a large rectangular house associated with a surrounding habitation area or unenclosed yard, at some point before the end of the millennium. It is difficult to say for how long this house was occupied but, given the evidence from the comparable settlement at Kinbeachie on the Black Isle for instance (Barclay et al 2001, 74; Noble 2006, 64 ), or the general perception that fully permanent settlements did not appear on mainland Scotland until the Bronze Age (Pollard 1997, 117; Brophy $2006,25)$ and even then were rather transient (Halliday 2007, 53-55), or indeed the absence of any evidence within Structure A for replacement posts, it is doubtful that this was for more than one or two generations.

Nevertheless, however transient the occupation of Structure A might appear from our perspective, the substantial form of this house may have appeared much more permanent during its lifespan. The majority of contemporary Neolithic settlement, exemplified by sites such as Beckton in Dumfries and Galloway (Pollard 1997), Chapelfield near Stirling (Atkinson 2002) and Overhailes in East Lothian (MacGregor \& Stuart 2007), appear significantly more ephemeral. Within the contemporary settlement hierarchy and economy that is beginning to emerge in the archaeological record (MacGregor 2007, 221; Murray et al 2009, 65; Bishop et al 2009, 90), Structure A at Laigh Newton belongs to that form of settlement less temporary than these slight tent-like structures, but also less imposing and ceremonial than the monumental halls such as Balbridie and Claish, perhaps analogous with the idea of a permanent farmhouse around which a small, probably kinship-based, community led a more mobile, perhaps pastoral and wild plant-based lifestyle.

A hiatus in occupation followed its abandonment until around the middle of the third millennium $\mathrm{BC}$, when a much more ephemeral form of structure occupied the area north of Structures A and C. Structure D was centred around pit 040, which contained large quantities of charcoal, consistent with domestic hearth waste (see Ramsay above), and which yielded radiocarbon dates of 2470-2280 cal BC (SUERC-22168) from its primary fill and 22902030 cal BC (SUERC-22414) from its uppermost fill. Although the sides of the pit were not significantly burnt, the amount of charcoal suggests this was a fire pit. The presence of hazel nutshell and a raspberry/bramble pip also indicates that food was probably being prepared or eaten here. Surrounding this fire-pit was a trapezoidal arrangement of postholes, one of which contained a fragment of daub, perhaps indicative of a wind- and water-tight wattle structure (see Ballin Smith above). The post-holes were significantly smaller than the post-holes that defined Structure A and together with the smaller floor space of $c 64 \mathrm{~m}^{2}$, Structure D seems consistent with the slight dwelling structures apparent across central and south-west Scotland around this time (Brophy 2006, 21). The radiocarbon dates obtained from two of the post-holes, though, might raise doubts as to whether these post-holes were contemporary with the fire-pit. Plough action and the proximity of the medieval linear feature overlying Structure A, however, may explain the contamination of post-hole 042 with a fragment of alder dated to cal AD 1030-1210 (SUERC-24627). The fragment of hazelnut shell from post-hole 034, which was radiocarbon dated to $4340-4060 \mathrm{cal} \mathrm{BC}$ (SUERC24628), is consistent with residual late Mesolithic and early Neolithic material apparent in other features at Laigh Newton, especially as a Beaker vessel sherd was recovered from the same posthole. The artefacts, which are perhaps less likely to have moved from their last place of deposition than charcoal micro fragments, were consistent with occupation during the late Neolithic/Early Bronze Age period; two small flakes of Yorkshire flint recovered from the upper fill of the fire-pit were roughly contemporary with the Beaker sherd (see Ballin above). Furthermore, a sherd from the same Beaker vessel was also found in the lower fill of pit 250 to the west of Structure D, which also contained a fragment of hazel, radiocarbon dated to 2470-2270 cal BC (SUERC-22411). In the absence of any diagnostically later artefacts from the neighbouring pits near the north-west corner of the western excavation area, it is likely that this coherent layout of pits was also contemporary with Structure D.

The mix of residual Mesolithic and Early Neolithic material within the only two pits of this group to contain artefacts, and the consistency of the charcoal from pit 250 with domestic hearth waste (see Ramsay above), strongly suggests that the accidental accumulation of domestic debris rather than structured deposition better explains the fill of these pits. The original digging of these pits, on the other hand, was clearly deliberate and structured, 
and remarkably similar to several clusters of early Neolithic pits discovered at Kilverstone in Norfolk (Garrow et al 2005, 152). As in Kilverstone, where also no pit cut another, these pits were probably dug sequentially, but were probably not around a now vanished feature within the centre of the Ushaped layout, as this area seems simply too small. Drawing on the scenarios envisaged for Kilverstone (ibid, 154-155) and Newton Farm near Cambuslang (O'Brien 2009, 21), this cluster of pits at Laigh Newton probably derives from a single episode of occupation. While the purpose of these pits and their layout is not discernible from the nature of their fills, their proximity to the contemporary trapezoidal structure might suggest an associated function. If these pits were dug in order to contain organic matter, such material would leave no archaeological trace. Even though these pits only survive to a very shallow depth, almost all of them contained more than one deposit of fill, suggesting that deposits were placed in them sequentially and perhaps relatively often. The haphazard inclusion of domestic debris that had accumulated here indicates that the content of the material used to fill the pits was not important, only perhaps that soil was required to be periodically dumped into the pits. That the soil close to hand may have been rich in domestic debris is not inconceivable, given the evidence from settlements such as Durrington Walls for instance (Parker Pearson 2007, 142), where the original, middenrich, ground surface survives. Given their location a short distance from, but not too close to, a possible domestic dwelling, these pits at Laigh Newton may have been latrines. To take an ethnographic example of the adaptation from a nomadic lifestyle to a more permanent occupation of a site, the imposition of a sedentary lifestyle upon the nomadic Mbuti Pygmies of Central Africa, where after only two months the new model villages were filthy, reeked of garbage and human excreta and had been all but abandoned (Turnbull 1983, 148-9), suggests that the management of general waste and specifically human waste disposal was probably highly significant to communities coming to terms with the occupation of fixed places for more than a few weeks. The same purpose of latrines may also explain the pits within the central excavation site, which also contained a mix of residual early Neolithic, later Neolithic and Bronze Age domestic debris. Even if these other pits did not relate directly to the occupation of Structure D, they are still likely indicators (Pollard 1997, 112) for broadly contemporary settlement along the same valley terrace.

Also possibly contemporary with this episode of occupation was Structure B, near the east side of the western excavation area. Measuring $6 \mathrm{~m}$ long and $3.5 \mathrm{~m}$ wide, this NE/SW-aligned post-built rectilinear structure was significantly smaller than Structure A, covering a floor space of just $21 \mathrm{~m}^{2}$. However, while radiocarbon dates of 2850-2470 cal BC (SUERC-24625) and 2460-2140 cal BC (SUERC24626) were obtained from two of its post-holes, a date of 520-370 cal BC (SUERC-22405) was obtained from another of its post-holes. In the absence of any artefactual evidence, it is therefore impossible to attribute with any certainty the date of this structure. As with Structure A, the charcoal evidence was more indicative of domestic hearth waste than structural debris (see Ramsay above) but, together with the absence of any artefacts, offered no clues as to what specific activities took place within this structure. While Structure B was small enough to have been roofed, the post-holes were very shallow and likely post diameters could not be estimated with any confidence. A rectilinear structure is of course less unusual in the third millennium than the first millennium $\mathrm{BC}$, but rectilinear structures were not entirely absent from Britain during the pre-Roman Iron Age (Cunliffe 2005, 561-3). While the single fragment of charcoal radiocarbon dated to the Iron Age may be a later contaminant, and therefore unrelated to its occupation, comparable radiocarbon dates of 410-350 cal BC (SUERC-22430) from residual alder charcoal downslope on the north-west excavation site, and 400-200 cal BC (SUERC-24629) from the fill of Structure E and 380-200 cal BC (SUERC-22440) from charred barley grains in a pit, both within the central excavation site, altogether demonstrate credible evidence for occupation along this valley terrace during the mid first millennium BC. If indeed Structure B was built and occupied at this time, one might speculate if its unusual form, analogous with the broadly contemporary rectilinear 'shrines' recorded in southern Britain (Cunliffe 2005, 561-563) and quite distinct from the ubiquitous circular form of contemporary domestic settlement in Scotland, was related to the perceived pre-Christian religious importance of Loudoun Hill and its association with the Celtic deity Lug (MacGregor \& Atkinson 2000, 65), in the direction of which the axis of Structure B is aligned (illus 5 and 17). However, the evidence is simply not clear enough to substantiate such speculation and the date of Structure B is thus indeterminate.

The focus of settlement on the western excavation site at Laigh Newton nevertheless appears to have shifted slightly to the east later in the Bronze Age, where a pit containing significant numbers of carbonised barley provided a radiocarbon date of 1690-1500 cal BC (SUERC-22433). The bulk of the prehistoric radiocarbon dates from the medieval farmstead downslope from this, on the northwest excavation site, were broadly contemporary (see table 5) and due to their final deposition here through topsoil creep and ploughing, their most likely origin lies somewhere on the eastern margin of the western excavation area.

The last phase of prehistoric occupation apparent at Laigh Newton appears to have taken place right at the end of the Iron Age. This comprised a large rectangular pit in the north-east quarter of Laigh Newton Central, which contained bundles of carbonised branches that had been burnt in situ within it. The incomplete combustion of the upper fragments, 
the similar size of the roundwood pieces and the selection solely of birch and alder, together with the complete absence of food plant remains, indicates that the purpose of this burning was the production of charcoal (see Ramsay above).

A radiocarbon date of cal AD 380-540 (SUERC22435), obtained from a fragment of alder charcoal from the lower fill of this pit, was broadly contemporary with a radiocarbon date of cal AD $240-400$ (SUERC-22434) from Structure E, situated $5 \mathrm{~m}$ to the north-east. However, radiocarbon dates of 400 $200 \mathrm{cal}$ BC (SUERC-24629) and cal AD 1030-1220 (SUERC-24630) were also obtained from Structure E. Other than a couple of lithic fragments, including a chip of Neolithic Yorkshire flint, the rectilinear groove that defined this feature contained no other artefacts. The rest of the carbonised remains were consistent with hearth waste rather than structural debris and included a few carbonised oat grains. Enclosing a space $5.1 \mathrm{~m}$ long and $2.3 \mathrm{~m}$ wide, Structure $\mathrm{E}$ was of different construction to Structures A and B, with no evidence for upright posts (illus 11 and 18). The only evidence for a stake-hole within the base of the groove was recorded near the centre of its north side, but as this occurred precisely on the course of a modern field drain that cut through the groove, its pre-modern provenance is doubtful. Structure E is nonetheless broadly comparable with other rectilinear structures from the mid-late first millennium $\mathrm{AD}$ in southern Scotland (Smith 1982, 133; Smith 1995, 115; Ralston \& Armit 1997, 218 and 229), albeit at the cusp of rectilinear houses appearing again in the archaeological record. Given that charcoal-burning requires constant vigilance for its duration, it is conceivable that Structure E may have been some form of temporary shelter for those carrying out this task. There was, however, no evidence for any substantial load-bearing structure necessary to support a roof. The range of dating evidence recovered, therefore, does not allow the date of this structure to be confidently established and the date of Structure E is therefore indeterminate. 


\section{CONCLUSIONS}

While the archaeological evidence indicates that Laigh Newton was intermittently inhabited over seven millennia, for most of these periods the manner of occupation left largely ephemeral and ambiguous remains. The most coherent archaeological remains discovered at Laigh Newton reveal traits common to many Neolithic and Early Bronze Age sites in Scotland (Barclay 2003, 81). Prior, though enigmatic, Mesolithic use of the site is apparent, as is evident at other sites such as Spurryhillock (Alexander 1997, 25-6) and Chapelfield (Atkinson 2002, 185-8). The rectilinear structure of the fourth millennium $\mathrm{BC}$ and its association with arable farming is comparable, if not identical, with other contemporary settlements. The more ephemeral structure that succeeded this during the third millennium $\mathrm{BC}$ follows the general development of settlement forms on mainland Scotland (Brophy 2006, 22). The limited size of the artefactual assemblages at Laigh Newton is also consistent with mainland Neolithic assemblages in comparison with those of the Northern Isles. In general, the episodic nature of settlement at Laigh Newton reflects the generally intermittent nature of occupation of places in mainland Scotland up to and probably beyond the early Bronze Age, but where perhaps a collective memory of occupation and meaning was sustained, as has been postulated elsewhere (Murray et al 2009, 69).

However, what distinguishes Laigh Newton from many other contemporary Neolithic dwelling sites is the absence of any demonstrable evidence for overtly ritual activity. While it is stridently argued by many archaeologists that the domestic and ritual nature of occupation practices within Neolithic settlements cannot be separated from one another, a notion based largely on evidence gathered from anthropological and ethnographic case studies (Darvill 1996, 79), structured deposition of ritually charged material and the ritual symbolism of buildings must be archaeologically demonstrable. That there is no archaeological evidence for such ritual activity from the Neolithic settlements at Laigh Newton, or from many other sites in Britain and Ireland (Topping 1996, 170; Conolly \& MacSween 2003, 43; Jones \& Rowley-Conwy 2007, 406; Bishop et al 2009, 89), suggests that perceptions that Neolithic houses should not be considered dwellings but domestic ritual monuments (Topping 1996, 163; Brophy 2007, 92; Thomas 2008, 79-80) overstate the significance of ritual symbolism to everyday Neolithic life, perhaps reflecting modern preoccupations with cultural relativism (eg Thomas 1996, 1-12) more than the reality of the evidence. That it is recognised that prehistoric ritual activity occurred outside the domestic sphere (Bradley 2005, 35) means that it was possible for prehistoric people to separate ritual from the domestic. Assertions that ritual and domestic life in prehistory cannot be separated (ibid, 210) seem therefore to preclude the ability of prehistoric people to leave any archaeological trace other than for ritualised activity, which is hard to accept given that people during the following millennia appear to have had no trouble leaving very mundane archaeological remains. Even within a society where everyday activities were full of ritual, it was possible for people to deposit artefacts simply for practical reasons (Turnbull 1983, 31-2 and 41). Likewise, in a Neolithic Scotland where culture seems far from homogeneous (Barclay 2003, 81), and people did not spend all their time engaged in ritual activities (Thomas 2004, 171), it was surely possible for people to deposit material in a way that was not ritualised. Though elements of everyday activity were no doubt imbued with abstract cultural value and meanings, the archaeological evidence from Laigh Newton does not appear to allow any such interpretation to be garnered from the nature of the deposits.

Of course, only a partial understanding of the Neolithic settlement at Laigh Newton can be understood from the archaeological evidence that survived, plough truncation having removed the bulk of the archaeological remains from the record. But many other Neolithic settlements on mainland Britain are also affected by plough truncation and, if ritual activity can be recognised in the form of structured deposition in these other plough-truncated settlement sites, the absence of any such evidence at Laigh Newton, while not evidence of absence, cannot at the same time be unthinkingly dismissed as due entirely to post-deposition conditions.

However limited a picture of life the evidence from Laigh Newton offers, the nature of this evidence reflects the practical reality of life during the Neolithic, rather than the ritual perception of life. While 'practicality' may be unfashionable amongst some archaeologists, it is not a modern concept alien to the Neolithic (cf Richards 1996, 171), for it was practical activities that actually produced the food, clothes and shelter, however responsible symbolic acts may have been perceived by some. While nondomestic cultural activity is undoubtedly apparent in some Neolithic settlements, it is not apparent in all Neolithic settlements and it cannot therefore be assumed that all Neolithic people placed the same importance upon such ritualised activity, or shared the same perceptions of the world, as others did. 


\section{ACKNOWLEDGEMENTS}

The project was funded by Tarmac. GUARD is most grateful to Colin Hume from Tarmac for providing access, machinery and assistance for this work. Thanks are also due to Hugh McBrien and Dave Hodgson of the West of Scotland Archaeology Service for monitoring this project on behalf of East Ayrshire Council, and Gordon Cook of SUERC for the radiocarbon dating. Dave Swan directed the Laigh Newton West excavation, Charlotte Francoz directed the North-west excavation, Martin Carruthers directed the Central excavation, Joe Somerville directed the second phase evaluation including the eastern site and Kirsteen McLellan directed the initial evaluation. The excavators were Anne Bankier, Amanda Brend, Julie Candy, Chris Bowles, Martin Goldberg, Dianne Gorman, Amanda
Gow, Andrea Lynn Jackson, Maureen Kilpatrick, Donna Maguire, Mark McDonald, Scott McLeod, Paul Murtagh, Sophie Nicol, Gordon Noble, Tessa Poller, Christine Rennie, Dave Sneddon and Eland Stewart. Technical support was provided by John Arthur, Chris Connor, Lorraine McEwen, David Millar and Mel Richmond. Jennifer Cochrane and Laura Hayes provided administrative support. The lithic illustrations were prepared by Jo Bacon. Ingrid Shearer and Gillian McSwan prepared the remaining illustrations for this report. The various stages of this project were managed by John Atkinson, Gavin MacGregor and Beverley Ballin Smith. Comments on earlier drafts were kindly provided by Beverley Ballin Smith and Kenneth Brophy. 


\section{REFERENCES}

Addyman, T 2004 'Station Brae, Dreghorn, North Ayrshire', Discovery and Excavation in Scotland 5, 87-90.

Alexander, D 1997 'Excavation of Pits Containing Decorated Neolithic Pottery and Early Lithic Material of Possible Mesolithic Date at Spurryhillock, Stonehaven, Aberdeenshire', Proceedings of the Society of Antiquaries of Scotland 127, 17-27.

Atkinson, J A 2002 'Excavation of a Neolithic Occupation Site at Chapelfield, Cowie, Stirling', Proceedings of the Society of Antiquaries of Scotland 132, 139-192.

Ballin, T B 2002 'Later Bronze Age Flint Technology: A presentation and discussion of post-barrow debitage from monuments in the Raunds area, Northamptonshire', Lithics 23, 3-28.

Ballin, T B 2006 'Re-examination of the Early Neolithic pitchstone-bearing assemblage from Auchategan, Argyll, Scotland', Lithics 27, 12-32.

Ballin, T B 2009 Archaeological Pitchstone in Northern Britain. Characterisation and interpretation of an important prehistoric source. British Archaeological Reports British Series 476. Oxford: Archaeopress.

Ballin, T B forthcoming a 'The Late Neolithic lithic finds from Airhouse and Overhowden, near the Overhowden Henge, Scottish Borders. Characterisation and discussion of two unusual assemblages and their parent sites'. British Archaeological Reports British Series. Oxford: Archaeopress.

Ballin, T B forthcoming b "The British Late Neolithic "Levalloisian", and other operational schemas from the later prehistoric period. A discussion based on finds from the Stoneyhill Project, Aberdeenshire', submitted to Proceedings of the 'Flint and Stone in the Neolithic Period' Conference held by the British Neolithic Studies Group at the British Museum 2005.

Ballin, T B forthcoming c 'The Lithic Assemblage' in J C \& H K Murray, 'Garthdee Road, Aberdeen City, Aberdeenshire', Proceedings of the Society of Antiquaries of Scotland.

Ballin, T B \& Faithfull, J 2009 'Gazetteer of Arran Pitchstone Sources. Presentation of exposed pitchstone dykes and sills across the Isle of Arran, and discussion of the possible archaeological relevance of these outcrops', Scottish Archaeological Internet Reports 38.

Ballin, T B \& Johnson, M 2005 'A Mesolithic Chert Assemblage from Glentaggart, South Lanarkshire, Scotland: Chert Technology and Procurement Strategies', Lithics 26, 57-86.
Ballin Smith, B forthcoming 'The Coarse Pottery' in G MacGregor et al Excavations at Loch Lomond, Society of Antiquaries of Scotland.

Barclay, G J \& Russell-White, C J 1993 'Excavations in the ceremonial complex of the fourth to second millennium $\mathrm{BC}$ at Balfarg/Balbirnie, Glenrothes, Fife', Proceedings of the Society of Antiquaries of Scotland 123, 43-210.

Barclay, G J; Carter, S P; Dalland, M M; Hastie, M; Holden, T G; MacSween, A \& Wickham-Jones, C R 2001 'A possible Neolithic settlement at Kinbeachie, Black Isle, Highland', Proceedings of the Society of Antiquaries of Scotland 131, 57-85.

Barclay, G J; Brophy, K \& MacGregor, G 2002 'Claish, Stirling: An Early Neolithic Structure in its Context', Proceedings of the Society of Antiquaries of Scotland 132, 65-137.

Barclay, G J 2003 'Neolithic settlement in the Lowlands of Scotland: A Preliminary Survey', in I Armit; E Murphy; E Nells \& D Simpson (eds) Neolithic Settlement in Ireland and Western Britain, 71-83. Oxford: Oxbow Books.

Barker, P 1993 Techniques of Archaeological Excavation, London: Batsford.

Bishop, R R; Church, M J \& Rowley-Conwy, P A 2009 'Cereals, Fruits and Nuts in the Scottish Neolithic', Proceedings of the Society of Antiquaries of Scotland 139, 47-103.

Bradley, R 2005 Ritual and Domestic Life in Prehistoric Europe. Abingdon: Routledge.

Brophy, K \& Barclay, G J 2004 'A rectilinear timber structure and post-ring at Carsie Mains, Meikleour, Perthshire', Tayside \& Fife Archaeological Journal 10, 1-22.

Brophy, K 2006 'Rethinking Scotland's Neolithic: Combining Circumstance with Context', Proceedings of the Society of Antiquaries of Scotland $136,7-46$.

Brophy, K 2007 'From Big Houses to Cult Houses: Early Neolithic Timber Halls in Scotland', Proceedings of the Prehistoric Society 73, 75-96.

Butler, C 2005 Prehistoric Flintwork. Stroud: Tempus.

Cameron, I B \& Stephenson, D 1985 The Midland Valley of Scotland. British Regional Geology 5. London: HMSO.

Clark, J G D 1932 'Discoidal Polished Flint Knives - Their Typology and Distribution', Proceedings of the Prehistoric Society 6, 40-54.

Clarke, D L 1970 Beaker Pottery of Great Britain and Ireland. London: Cambridge University Press.

Conolly, R \& MacSween, A 2003 'A possible Neolithic settlement at Milton of Leys, Inverness', Pro- 
ceedings of the Society of Antiquaries of Scotland 133, 35-45.

Cook, M 2000 'Excavation of Neolithic and Bronze Age settlement features at Lamb's Nursery, Dalkeith, Midlothian', Proceedings of the Society of Antiquaries of Scotland 130, 93-113.

Cook, M \& Dunbar, L 2008 Rituals, Roundhouses and Romans: Excavations at Kintore, Aberdeenshire 2000-2006. Edinburgh: Scottish Trust for Archaeological Research.

Cunliffe, B 2005 Iron Age Communities in Britain. Fourth Edition. London: Routledge.

Darvill, T 1996 'Neolithic Buildings in England, Wales and the Isle of Man', in T Darvill \& J Thomas (eds) Neolithic Houses in Northwest Europe and Beyond, 77-111. Oxford: Oxbow Books.

Dickson, C A \& Dickson, J H 2000 Plants and People in Ancient Scotland. Stroud: Tempus.

Edlin, H 1973 Woodland Crafts of Britain. Newton Abbot: David \& Charles.

Evans, S J 1897 The Ancient Stone Implements, Weapons and Ornaments of Great Britain. London: Longmans, Green \& Co.

Evans, C; Pollard, J \& Knight, M 1999 'Life in Woods: Tree-throws, "settlement" and forest cognition', Oxford Journal of Archaeology 18 (3), 241-254.

Fairweather, A D \& Ralston, I B M 1993 'A Neolithic timber hall at Balbridie, Grampian Region, Scotland: the building, the date, the plant macrofossils', Antiquity 67, 313-23.

Gale, R \& Cutler, D 2000 Plants in Archaeology. Otley: Westbury \& Royal Botanic Gardens Kew.

Garrow, D; Beadsmore, E \& Knight, M 2005 'Pit Clusters and the Temporality of Occupation: an Earlier Neolithic Site at Kilverstone, Thetford, Norfolk', Proceedings of the Prehistoric Society 71, 139-157.

Graham, T 2003-04 'Wattle and Daub: Craft, Conservation \& Wiltshire Case Study'. Unpublished. University of Bath, MSc Dissertation (http:// www.tonygraham.co.uk/house_repair/wattle daub/WD.html) accessed 28/04/11.

Grogan, E 1996 'Neolithic Houses in Ireland', in T Darvill \& J Thomas (eds) Neolithic Houses in Northwest Europe and Beyond, 41-60. Oxford: Oxbow Books.

Guttmann, E B A; Dockrill, S J \& Simpson, I A 2004 'Arable agriculture in prehistory: new evidence from soils in the Northern Isles', Proceedings of the Society of Antiquaries of Scotland 134, 53-64.

Halliday, S P 2007 'Unenclosed round-houses in Scotland: occupation, abandonment and the character of settlement', in C Burgess; P Topping \& F Lynch (eds) Beyond Stonehenge: Essays on the Bronze Age in Honour of Colin Burgess, 49 56. Oxford: Oxbow Books.

Hogg, D J 2002 'Aspects of the Claish Structure', in G J Barclay et al 'Claish, Stirling: an early Neolithic structure in its context', Proceedings of the Society of Antiquaries of Scotland 132, 111-114.

James, $\mathrm{H}$ forthcoming 'A Medieval Farmstead at Laigh Newton North-west, East Ayrshire', Scottish Archaeological Internet Reports.

Jones, A 2005 'The Grooved Ware from Barnhouse', in $\mathrm{C}$ Richards Dwelling among the monuments: the Neolithic village of Barnhouse, Maeshowe passage grave and surrounding monuments at Stenness, Orkney, 261-281. Cambridge: McDonald Institute for Archaeological Research.

Jones, G \& Rowley-Conwy, P 2007 'On the importance of Cereal Cultivation in the British Neolithic', in S Colledge \& J Conolly (eds) The Origins and Spread of Domestic Plants in Southwest Asia and Europe, 391-419. London: University College London Institute of Archaeology Publications.

Kirby, M 2011 'Lockerbie Academy: Neolithic and Early Historic timber halls, a Bronze Age cemetery, an undated enclosure and a post-medieval corn-drying kiln in south-west Scotland', Scottish Archaeological Internet Report 46.

MacGregor, G 2007 'Changes in dwelling, people and place, $c$ 3500-1000 BC', in O Lelong \& G MacGregor (eds) The lands of Ancient Lothian: Interpreting the Archaeology of the A1, 221-237. Edinburgh: Society of Antiquaries of Scotland.

MacGregor, G \& Atkinson, J A 2000 'The Leven in Context' in J A Atkinson 'Excavations on the Leven, Loudoun Hill, Ayrshire, 1993,' Scottish Archaeological Journal 22 (1), 31-68.

MacGregor, G \& Stuart, E 2007 'Everything in its Place: Excavations at Eweford, Overhailes, Pencraig Wood and Eweford Cottages (3300 1700 BC)', in O Lelong \& G MacGregor (eds) The lands of Ancient Lothian: Interpreting the Archaeology of the A1, 69-98. Edinburgh: Society of Antiquaries of Scotland.

MacSween, A 1995 'Grooved Ware from Scotland: aspects of decoration', in I Kinnes \& G Varndell (eds) Unbaked Urns of Rudely Shape: essays on British and Irish Pottery for Ian Longworth. Oxbow Monograph 55. Oxford: Oxbow Books.

MacSween, A 2007 'The Neolithic Pottery', in J Hunter Investigations in Sanday, Orkney: Volume 1: Excavations at Pool, Sanday. A multiperiod settlement from Neolithic to Late Norse times, 287-306. Kirkwall: Orcadian in association with Historic Scotland.

Malone, C 2001 Neolithic Britain and Ireland. Stroud: Tempus.

Mithen, S; Findlay, N; Carruthers, W; Carter, S \& Ashmore, P 2001 'Plant use in the Mesolithic: Evidence from Staosnaig, Isle of Colonsay, Scotland', Journal of Archaeological Science 28, 223-234.

Murray, H K; Murray, J C \& Fraser, S M 2009 A Tale of the Unknown Unknowns: A Mesolithic pit alignment and a Neolithic timber hall at 
Warren Field, Crathes, Aberdeenshire. Oxford: Oxbow Books.

Noble, G 2006 Neolithic Scotland: Timber, stone, earth and fire. Edinburgh: Edinburgh University Press.

O'Brien, L 2009 'Neolithic Pits, a Bronze Age Cremation and an Early Iron Age Ring-ditch at Newton Farm, Cambuslang, Lanarkshire', Scottish Archaeological Journal 31 (1-2), 1-31.

Parker Pearson, M 2007 'The Stonehenge Riverside Project: Excavations at the East Entrance of Durrington Walls', in M Larsson \& M Parker Pearson (eds) From Stonehenge to the Baltic, 125-144. Oxford: Archaeopress.

Pellant, C 1992 Rocks and Minerals. The visual guide to over 500 rock and mineral specimens from around the world. London: Dorling Kindersley.

Pollard, T 1997 'Excavation of a Neolithic settlement and ritual complex at Beckton Farm, Lockerbie, Dumfries and Galloway', Proceedings of the Society of Antiquaries of Scotland 127, 69-121.

Pritchett, I 2001 'Wattle and Daub', Building Conservation Directory 2001. London: Cathedral Communications.

Ralston, I B M \& Armit, I 1997 'The Early Historic Period: An Archaeological Perspective', in K J Edwards \& I B M Ralston (eds) Scotland: Environment and Archaeology, 8000 BC -AD 1000, 217-239. Chichester: John Wiley \& Sons Ltd.

Richards, C 1996 'Life is Not That simple: Architecture and Cosmology in the Balinese house', in T Darvill \& J Thomas (eds) Neolithic Houses in Northwest Europe and Beyond, 171-184. Oxford: Oxbow Books.

Saville, A 1994 'Exploitation of Lithic Resources for Stone Tools in Earlier Prehistoric Scotland', in N Ashton \& A David (eds) Stories in Stone, Lithic Studies Society Occasional Paper 4, 57-70. London: Lithic Studies Society, British Museum.

Shaffer, G D 1993 'An Archaeomagnetic Study of a Wattle and Daub Building Collapse', Journal of Field Archaeology 20 (1), 59-75.

Sheridan, A 2007 'Early Neolithic Carinated Bowl pottery', in O Lelong \& G MacGregor (eds) The Lands of Ancient Lothian: Interpreting the
Archaeology of the A1, 213. Edinburgh: Society of Antiquaries of Scotland.

Smith, AN 1995 'The excavation of Neolithic, Bronze Age and Early Historic features near Ratho, Edinburgh', Proceedings of the Society of Antiquaries of Scotland 125, 69-138.

Smith, I M 1982 'Excavations at the Dod 19791981', in D W Harding (ed) Later Prehistoric Settlement in South-east Scotland, University of Edinburgh Department of Archaeology Occasional Paper 8, 129-135. Edinburgh: University of Edinburgh.

Thomas, J 1996 'Neolithic Houses in Mainland Britain and Ireland - A Sceptical View', in T Darvill \& J Thomas (eds) Neolithic Houses in Northwest Europe and Beyond, 1-12. Oxford: Oxbow Books.

Thomas, J 2004 'The Ritual Universe', in I A G Shepherd \& G J Barclay (eds) Scotland in Ancient Europe: The Neolithic and Early Bronze Age of Scotland in their European Context, 171-178. Edinburgh: Society of Antiquaries of Scotland.

Thomas, J 2008 'The Mesolithic-Neolithic Transition in Britain', in J Pollard (ed) Prehistoric Britain, 58-59. Oxford: Blackwell.

Toolis, R 2007 'Intermittent occupation and forced abandonment: excavation of an Iron Age promontory fort at Carghidown, Dumfries and Galloway', Proceedings of the Society of Antiquaries of Scotland 137, 265-318.

Topping, P 1996 'Structure and ritual in the Neolithic house: some examples from Britain and Ireland', in $\mathrm{T}$ Darvill \& $\mathrm{J}$ Thomas (eds) Neolithic Houses in Northwest Europe and Beyond, 157-170. Oxford: Oxbow Books.

Turnbull, C M 1983 The Mbuti Pygmies: Change and Adaptation. New York: CBS College Publishing.

Williams Thorpe, O \& Thorpe, R S 1984 'The Distribution and Sources of Archaeological Pitchstone in Britain', Journal of Archaeological Science 11, $1-34$.

Woodland, A W 1979 Geological Map of the United Kingdom North (North of National Grid Line $500 \mathrm{~km} \mathrm{~N}$ ). $3^{\text {rd }}$ Edition. Southampton: Ordnance Survey for the British Geological Survey. 


\section{APPENDIX 1: CATALOGUE OF LAIGH NEWTON WEST POTTERY SHERDS}

\begin{tabular}{|c|c|c|c|}
\hline Catalogue No. & Context & Type & Comments \\
\hline 59 & 007 & & One body sherd with carbonised food deposits. \\
\hline 60 & 009 & & One body sherd with carbonised food deposits. \\
\hline 61 & 021 & & Pottery sliver. \\
\hline 62,63 & 055 & $\begin{array}{l}\text { Early Neolithic } \\
\text { bowl }\end{array}$ & $\begin{array}{l}\text { Two malformed and everted rims from a carinated vessel decorated } \\
\text { on slightly flattened top with areas of fine oblique of incised lines. } \\
\text { Has finger nicks under rim. One sherd has two oblique patterns of } \\
\text { fine combed lines } c \text { 0.5mm apart, fields } c 7 \mathrm{~mm} \text { apart. Edges rolled } \\
\text { and eroded. Broken along join. Vessel } 11 .\end{array}$ \\
\hline 64 & 137 & & Small fragment of pottery not recorded further. \\
\hline 65 & 149 & & Large grit from pot. \\
\hline 66,78 & $\begin{array}{l}160 \\
\& 278\end{array}$ & Beaker vessel & $\begin{array}{l}\text { Two body sherds with five incised horizontal combed lines. Teeth } \\
\text { of comb } 2 \mathrm{~mm} \text { by } 1 \mathrm{~mm} \text {. Lines } 1.5-2 \mathrm{~mm} \text { apart. Surfaces smooth and } \\
\text { polished, and eroded rounded edges. Vessel } 12 \text {. }\end{array}$ \\
\hline 68,71 & 258 & $\begin{array}{l}\text { Early Neolithic } \\
\text { bowl }\end{array}$ & $\begin{array}{l}\text { Two body sherds smoothed and polished with edges around upper } \\
\text { surface quite worn. One has two incised parallel lines } 19 \text { and } 22 \mathrm{~mm} \\
\text { long, } 1 \mathrm{~mm} \text { wide. Surface cracking and pitting. Slipped with mica } \\
\text { dust and burnished. Vessel } 13 \text {. }\end{array}$ \\
\hline 70 & 258 & Neolithic & $\begin{array}{l}\text { Body sherd possibly not decorated, but has loss of coarse quartz or } \\
\text { other grains from surface. Surface pitting /incised dots. Natural? } \\
\text { Possibly slipped, smoothed/burnished. }\end{array}$ \\
\hline 72 & 258 & Grooved Ware & $\begin{array}{l}\text { Sherd with cord impressed and triple cordon. Rim missing, but } \\
\text { fragments of two horizontal cords on interior. Cordons 9-10mm wide } \\
\text { are pinched not applied, with S twist 1mm wide cord impressed lines } \\
\text { above and below, 8-10mm wide. Uncertain surface finishing, but } \\
\text { finger impressions and some trimming of decoration. Has carbonised } \\
\text { food deposits. Vessel } 14 \text {. }\end{array}$ \\
\hline $\begin{array}{l}69,73,74,75,76 \\
77\end{array}$ & 258 & Beaker vessel & $\begin{array}{l}\text { Beaker base } 22 \% \text { present, } 70 \mathrm{~mm} \text { diameter with medium-sized grits. } \\
\text { Cord S twist, impressed } 1-2 \mathrm{~mm} \text { wide, } 5-6 \mathrm{~mm} \text { above base with single } \\
\text { horizontal cord impression above. } \\
\text { Body sherds with horizontal cord incised impressions } 10-27 \mathrm{~mm} \text { long, } \\
0.5-2 \mathrm{~mm} \text { wide, and } 3-4 \mathrm{~mm} \text { apart. Vessel is sooted, has carbonised } \\
\text { food deposits and originally was slipped, smoothed and burnished. } \\
\text { One rim } 70 \mathrm{~mm} \text { diameter and } c 8 \% \text { present. Slightly everted with } \\
\text { slight bulge and faint cord lines below. Total of } 17 \text { sherds. Vessel } 15 \text {. }\end{array}$ \\
\hline 79 & 281 & & $\begin{array}{l}\text { Sherd heavily gritted with quartz. Has prominent fingernail } \\
\text { impression. }\end{array}$ \\
\hline 80 & 307 & & Heavily eroded sherd, with v rounded edges. Not recorded further. \\
\hline 81 & $u / s$ & & $\begin{array}{l}\text { Possibly burnt body sherd, one 'surface' is red. Rolled edges and loss } \\
\text { of surface. }\end{array}$ \\
\hline 82 & $\mathrm{u} / \mathrm{s}$ & Beaker vessel & Very small sherd of Beaker pottery. \\
\hline 83 & $\mathrm{u} / \mathrm{s}$ & Neolithic & $\begin{array}{l}\text { Two joining body sherds and one other. Pale reddish-brown sandy } \\
\text { interior. Very similar to sherds from Area B. Eroded and pitted, but } \\
\text { originally burnished. Has sooting/carbonised food deposits. Contains } \\
\text { a variety of temper including soft pale rock. Vessel } 16 \text {. }\end{array}$ \\
\hline
\end{tabular}




\section{APPENDIX 2: CATALOGUE OF LAIGH NEWTON NORTH-WEST POTTERY SHERDS}

\begin{tabular}{|c|c|c|c|}
\hline Catalogue No. & Context & Type & Comments \\
\hline 85 & $2490 \mathrm{~B}-\mathrm{u} / \mathrm{s}$ & Neolithic & $\begin{array}{l}\text { Fingermarks round malformed base edge or carination. Grey } \\
\text { interior surface. Was slipped and burnished, with vegetation } \\
\text { impressions and carbonised food deposits. Some surface pitting. } \\
\text { Similar to Catalogue No. } 83 \text {. }\end{array}$ \\
\hline 84 & $2490 \mathrm{~B}-\mathrm{u} / \mathrm{s}$ & & $\begin{array}{l}\text { Slightly rounded edges to sherd. Surface treatments largely lost due } \\
\text { to conditions of deposition. Vegetation impressions noted and some } \\
\text { surface smoothing. }\end{array}$ \\
\hline 86 & 2490B-374 & Neolithic & $\begin{array}{l}\text { Food deposits on both surfaces. Pinched basal edge. Possibly slipped } \\
\text { and burnished (some mica is present), also carbonised food deposits. } \\
\text { Also coated with sand/soft iron pan. Five sherds. }\end{array}$ \\
\hline 87 & 2490B-55010 & & Body sherd with some burnishing. \\
\hline 88 & 2490B-55005 & & Crumbs not recorded further. \\
\hline
\end{tabular}




\section{APPENDIX 3: CATALOGUE OF LAIGH NEWTON CENTRAL POTTERY SHERDS}

\begin{tabular}{|c|c|c|c|}
\hline Catalogue No. & Context & Type & Comments \\
\hline 13,16 & 298 & Neolithic & $\begin{array}{l}\text { Two rims and twelve body sherds plus crumbs. Rim everted, elongated } \\
\text { and rounded, } 210 \mathrm{~mm} \text { diameter } c 9 \% \text { present. Slipped with mica and } \\
\text { burnished. Ext food deposits. Burnt out seed impressions on ext. Plus } 58 \mathrm{~g} \\
\text { crumbs. Very coarse temper. Total of } 10 \text { sherds. Vessel } 4 \text {. }\end{array}$ \\
\hline 14,17 & 296 & Neolithic & $\begin{array}{l}\text { Body sherds (2) and crumbs possibly slipped and wiped. Internal food } \\
\text { deposits on larger sherd and externally sooted. Pitted due to loss of } \\
\text { temper (mineral and vegetable), with flaky, pitted surface. }\end{array}$ \\
\hline 15,18 & 294 & Neolithic & $\begin{array}{l}\text { Internal surface of body sherd is smoothed or has much burnt food } \\
\text { deposits, Vessel used when cracked. External surface smoothed, not } \\
\text { slipped or burnished. One finger indentation. Sandy texture to surface. } \\
\text { Total four sherds. Probably all same pot? Vessel } 5 \text {. }\end{array}$ \\
\hline 23 & 212 & & $\begin{array}{l}\text { Two undistinguished body sherds, one sherd thinner than the other, pale } \\
\text { red in colour - burnt? }\end{array}$ \\
\hline 25 & 212 & & Two sandy sherds with surface lost. \\
\hline $\begin{array}{l}22,26,28,29 \\
30\end{array}$ & 212 & & Nine body sherds and crumbs, some surface loss. \\
\hline 27 & 212 & Neolithic & Very small folded over rim. Probably Neolithic. \\
\hline 31 & 214 & Bronze Age & $\begin{array}{l}\text { Three coarse, thick sherds. Curved corner between body and base. Loss of } \\
\text { surface treatments. Root infiltration. Possible urn fragment. Vessel } 6 \text {. }\end{array}$ \\
\hline $32,33,34,35$ & 228 & & Seven body sherds and crumbs not recorded further. \\
\hline 36 & 228 & & Fragmentary rim sherd. \\
\hline 38,39 & 230 & & Ten body sherds with loss of exterior surface, and crumbs. \\
\hline 40 & 230 & Grooved Ware & $\begin{array}{l}\text { Five small sherds with evidence of a vertical and horizontal sallow stab } \\
\text { and drag decoration } c 3 \mathrm{~mm} \text { wide. Made with a stick. Inner surface is lost } \\
\text { and external surface is abraded. Total of } 11 \text { sherds. Vessel } 7 \text {. }\end{array}$ \\
\hline 41 & 230 & $\begin{array}{l}\text { Early Neolithic } \\
\text { Vessel }\end{array}$ & $\begin{array}{l}\text { One body sherd, possibly part of a Neolithic vessel. Slipped and } \\
\text { burnished. }\end{array}$ \\
\hline 42 & 286 & & $\begin{array}{l}\text { Two sherds with loss of surface treatments but with carbonised food } \\
\text { deposits. }\end{array}$ \\
\hline $43,44,47,49$ & 294 & & $\begin{array}{l}\text { Coarse gritted body sherds (8) but may have been slipped and burnished. } \\
\text { Two with carbonised food deposits and one with vegetation impressions. }\end{array}$ \\
\hline 45,48 & 294 & $\begin{array}{l}\text { Early Neolithic } \\
\text { Vessel }\end{array}$ & $\begin{array}{l}\text { Rim and body sherds (2). Rim from slipped and highly burnished vessel. } \\
\text { Has carbonised food deposits. Vessel } 8 \text {. }\end{array}$ \\
\hline 46 & 294 & Bronze Age & $\begin{array}{l}\text { Coarse gritted sherd. Grass marks from wiping on remaining surface. } \\
\text { Surface loss. }\end{array}$ \\
\hline 50 & 294 & Bronze Age & Crumbs with one laminated body sherd. Not recorded further. \\
\hline 51,56 & 296 & $\begin{array}{l}\text { Impressed } \\
\text { Ware/Grooved } \\
\text { Ware }\end{array}$ & $\begin{array}{l}\text { Decorated body sherd with small pinched raised area. Small pinched boss } \\
7-8 \mathrm{~mm} \text { wide on surface of sherd. Possibly burnished. Has finger impres- } \\
\text { sions and carbonised food deposits. One additional sherd. Vessel } 9 .\end{array}$ \\
\hline 52 & 296 & Bronze Age & $\begin{array}{l}\text { Body sherd sandy and thick with very coarse temper. Surface finishing is } \\
\text { lost. }\end{array}$ \\
\hline 53,55 & 296 & Early Neolithic & $\begin{array}{l}\text { Slipped and probably highly burnished body sherds (2) with carbonised } \\
\text { food deposits. }\end{array}$ \\
\hline 54 & 296 & & Two body sherds and crumbs, not recorded further. \\
\hline 57 & 304 & $\begin{array}{l}\text { Impressed } \\
\text { Ware/Grooved } \\
\text { Ware }\end{array}$ & $\begin{array}{l}\text { Decorated body sherd with five parallel stab lines } 2-3 \mathrm{~mm} \text { apart. Max. of } \\
\text { five stabs per line. Slabs measure } 4 \times 1.5 \mathrm{~mm} \text {. Loss of internal surface. } \\
\text { External surface is slipped and highly burnished. Coarse grits. Vessel } 10 \text {. }\end{array}$ \\
\hline
\end{tabular}




\section{APPENDIX 4: CATALOGUE OF LAIGH NEWTON EAST POTTERY SHERDS}

\begin{tabular}{|c|c|c|c|}
\hline $\begin{array}{l}\text { Catalogue } \\
\text { No. }\end{array}$ & Context & Type & Comments \\
\hline 1,2 & 39005 & $\begin{array}{l}\text { Early Neolithic } \\
\text { bowl }\end{array}$ & $\begin{array}{l}\text { Two everted rims too small to be measured and one body. Rim is knife- } \\
\text { finished. Vessel slipped with mica dust and burnished to a dark finish. } \\
\text { With carbonised food deposits. Another body sherd possibly from another } \\
\text { vessel. }\end{array}$ \\
\hline 3 & 39007 & $\begin{array}{l}\text { Early Neolithic } \\
\text { vessel }\end{array}$ & $\begin{array}{l}\text { Total of nine sherds, including two base edge sherds. Coarse tempered } \\
\text { burnished sherds but some vegetation impressions and carbonised food } \\
\text { deposits. Some loss of surfaces. Two body sherds with grass impressions } \\
\text { and two others with sandy surface. One orange sherd from possibly a } \\
\text { different vessel. }\end{array}$ \\
\hline 4,5 & 39007 & & $\begin{array}{l}\text { Five very rolled and small body sherds including pottery slivers with no } \\
\text { surfaces. }\end{array}$ \\
\hline 6,8 & 39007 & $\begin{array}{l}\text { Early Neolithic } \\
\text { bowl }\end{array}$ & $\begin{array}{l}\text { Four adjoining sherds including three rims and other sherds. Rim } \\
\text { straight/everted and fold over to a straight neck. } 200 \mathrm{~mm} \text { diameter. Well- } \\
\text { burnished surfaces, knife timed and possibly slipped but with carbonised } \\
\text { food deposits. Approximately } 9 \% \text { of rim present. Total of } 10 \text { sherds. } \\
\text { Vessel } 1 .\end{array}$ \\
\hline 7 & 39007 & $\begin{array}{l}\text { Early Neolithic } \\
\text { bowl }\end{array}$ & $\begin{array}{l}\text { Three sherds to a vessel finer than Catalogue Nos } 6 \text { and } 7 . \\
\text { Vessel } 2 .\end{array}$ \\
\hline $9,10,11,12$ & 39007 & $\begin{array}{l}\text { Early Neolithic } \\
\text { bowl }\end{array}$ & $\begin{array}{l}\text { One thick rim sherd representing } 10 \% \text { of diameter, slightly everted and } \\
\text { rounded with fine surface finish. Finger moulding still evident. } 220 \mathrm{~mm} \\
\text { diameter. Other sherds from near base. Sherds slipped with mica dust, } \\
\text { smoothed and burnished but some surface loss. Some knife marks } \\
\text { around rim, also vegetable impressions, carbonised food deposits and } \\
\text { internal wipe marks. Small patch of fluting. Ten sherds in total. Vessel } \\
3 \text {. }\end{array}$ \\
\hline
\end{tabular}




\section{APPENDIX 5: CATALOGUE OF DAUB PIECES FROM LAIGH NEWTON}

\begin{tabular}{|c|c|c|c|}
\hline Catalogue No. & Area \& Context & No. Pieces & Description \\
\hline 19 & $\begin{array}{l}\text { Laigh Newton Central } \\
\mathrm{u} / \mathrm{s}\end{array}$ & 1 & Probable daub, contains no temper. \\
\hline 20 & $\begin{array}{l}\text { Laigh Newton Central } \\
\mathrm{u} / \mathrm{s}\end{array}$ & 1 & $\begin{array}{l}\text { Probable daub, contains no temper. Rounded soft, pitted } \\
\text { clay. }\end{array}$ \\
\hline 21 & $\begin{array}{l}\text { Laigh Newton Central } \\
\mathrm{u} / \mathrm{s}\end{array}$ & 1 & $\begin{array}{l}\text { Daub. Contains no temper. Burnt red. Surface depres- } \\
\text { sion, max } 5 \mathrm{~mm} \text { wide. }\end{array}$ \\
\hline 24 & $\begin{array}{l}\text { Laigh Newton Central } \\
\text { Context } 212\end{array}$ & 1 & $\begin{array}{l}\text { Like a malformed rim. Plaque or trial piece. Surface } \\
\text { smoothed. }\end{array}$ \\
\hline 37 & $\begin{array}{l}\text { Laigh Newton Central } \\
\text { Context } 228\end{array}$ & 1 & $\begin{array}{l}\text { Slight inturned piece but uncertain form. No surface } \\
\text { finish. }\end{array}$ \\
\hline 58 & $\begin{array}{l}\text { Laigh Newton West } \\
\text { (ET3 southern extension } \\
\text { trench) } \\
\text { Context } 019\end{array}$ & 5 & $\begin{array}{l}\text { Clay artefact } 6.8-7.9 \mathrm{~mm} \text { thick, probably not fired, but } \\
\text { one or two edges rounded. Surfaces smoothed. Uncertain } \\
\text { what shape it was. Has a large seed impression. Five } \\
\text { fragments. Small plain clay piece - with a plant impres- } \\
\text { sion (poppy?) }\end{array}$ \\
\hline 67 & $\begin{array}{l}\text { Laigh Newton West } \\
\text { Context } 198\end{array}$ & 3 & $\begin{array}{l}\text { Three fragments of a clay /daub roundel. No mineral } \\
\text { inclusions. }\end{array}$ \\
\hline Total & & 13 & \\
\hline
\end{tabular}




\section{APPENDIX 6: CATALOGUE OF LITHIC ASSEMBLAGES FROM LAIGH NEWTON}

\begin{tabular}{|c|c|c|c|c|c|c|c|c|}
\hline $\begin{array}{l}\text { CAT } \\
\text { No. }\end{array}$ & Area & Context & Type & $\begin{array}{l}\text { Raw- } \\
\text { material }\end{array}$ & $\begin{array}{c}\mathbf{L} \\
(\mathbf{m m})\end{array}$ & $\begin{array}{c}\mathrm{W} \\
(\mathrm{mm})\end{array}$ & $\begin{array}{c}\text { Th } \\
(\mathbf{m m})\end{array}$ & Comments \\
\hline 1 & Central & $\mathrm{u} / \mathrm{s}$ & Flake & Chert & 44.00 & 29.00 & 13.00 & \\
\hline 2 & Central & $\mathrm{u} / \mathrm{s}$ & Flake & Quartz & 18.00 & 11.00 & 2.00 & \\
\hline 3 & Central & $\mathrm{u} / \mathrm{s}$ & $\begin{array}{l}\text { Polished chunk/ } \\
\text { indet. piece }\end{array}$ & Flint & 24.00 & 20.00 & 6.00 & $\begin{array}{l}\text { Although the flint has a striated } \\
\text { (polished?) surface, this surface is } \\
\text { rather flat, where it would have } \\
\text { been expected to be more domed, } \\
\text { if it came from a disintegrated } \\
\text { axehead. Exotic flint, probably } \\
\text { from Yorkshire. }\end{array}$ \\
\hline 4 & Central & $\mathrm{u} / \mathrm{s}$ & $\begin{array}{l}\text { Flake with } \\
\text { edge-retouch }\end{array}$ & Chert & 18.00 & 24.00 & 6.00 & $\begin{array}{l}\text { The piece has a small area of } \\
\text { surviving retouch at the left } \\
\text { corner of the proximal break. }\end{array}$ \\
\hline 5 & Central & $\mathrm{u} / \mathrm{s}$ & Blade & Pitchstone & 34.00 & 10.00 & 4.00 & \\
\hline 6 & Central & $\mathrm{u} / \mathrm{s}$ & Flake & Flint & 13.00 & 9.00 & 5.00 & \\
\hline 7 & Central & $\mathrm{u} / \mathrm{s}$ & Flake & Quartz & 13.00 & 5.00 & 4.00 & \\
\hline 8 & Central & $\mathrm{u} / \mathrm{s}$ & $\begin{array}{l}\text { Flake with } \\
\text { edge-retouch }\end{array}$ & Flint & 40.00 & 29.00 & 14.00 & \\
\hline 9 & Central & $\mathrm{u} / \mathrm{s}$ & Flake? & Agate & 12.00 & 10.00 & 6.00 & \\
\hline 10 & Central & 52 & Flake & Quartz & 14.00 & 6.00 & 4.00 & \\
\hline 11 & Central & 32 & Flake & Quartz & 37.00 & 28.00 & 20.00 & \\
\hline 12 & Central & $\mathrm{u} / \mathrm{s}$ & Flake & Flint & 13.00 & 17.00 & 3.00 & Possibly some distal use-wear. \\
\hline 13 & Central & 270 & Chip & Flint & & & & $\begin{array}{l}\text { Exotic flint, probably from } \\
\text { Yorkshire. }\end{array}$ \\
\hline 14 & Central & 212 & Blade & Flint & 24.00 & 12.00 & 4.00 & \\
\hline 15 & Central & 296 & $\begin{array}{l}\text { Scale-flaked } \\
\text { knife }\end{array}$ & Flint & 29.00 & 40.00 & 7.00 & $\begin{array}{l}\text { Sub-triangular shape. Morpho- } \\
\text { logically related to a polished } \\
\text { piece from Kempston, near } \\
\text { Bedford, England (Evans } 1897 \text {, } \\
\text { fig. } 256 \text { ). Probably of a later } \\
\text { Neolithic date. Probably exotic } \\
\text { flint from Yorkshire. }\end{array}$ \\
\hline 16 & Central & 272 & $\begin{array}{l}\text { Chunk/indet. } \\
\text { piece }\end{array}$ & Flint & 12.00 & 14.00 & 6.00 & Probably exotic flint (Yorkshire?) \\
\hline 17 & Central & 218 & Flake & Flint & 13.00 & 18.00 & 2.00 & \\
\hline 18 & Central & $\mathrm{u} / \mathrm{s}$ & $\begin{array}{l}\text { Chunk/indet. } \\
\text { piece }\end{array}$ & Flint & 13.00 & 7.00 & $\begin{array}{r}2.0 \\
0\end{array}$ & \\
\hline 19 & West & 116 & Flake & Flint & 30.00 & 22.00 & 6.00 & \\
\hline 20 & West & 258 & Microblade & Pitchstone & 15.00 & 7.00 & 3.00 & \\
\hline 21 & West & 258 & $\begin{array}{l}\text { Blade w } \\
\text { edge-retouch }\end{array}$ & Flint & 12.00 & 12.00 & 3.00 & $\begin{array}{l}\text { Discrete blunting of the bulbar } \\
\text { area - minuscule chips have been } \\
\text { detached from either face. }\end{array}$ \\
\hline 22 & West & $\mathrm{u} / \mathrm{s}$ & Flake & Flint & 15.00 & 13.00 & 2.00 & $\begin{array}{l}\text { Some use-wear along the left } \\
\text { lateral side. }\end{array}$ \\
\hline 23 & $\begin{array}{l}\text { North- } \\
\text { west }\end{array}$ & 83 & $\begin{array}{l}\text { Blade with } \\
\text { oblique } \\
\text { truncation }\end{array}$ & Flint & 33.00 & 15.00 & 5.00 & \\
\hline 24 & $\begin{array}{l}\text { North- } \\
\text { west }\end{array}$ & $\mathrm{u} / \mathrm{s}$ & Flake & Chert & 38.00 & 23.00 & 11.00 & \\
\hline
\end{tabular}




\begin{tabular}{|c|c|c|c|c|c|c|c|c|}
\hline $\begin{array}{l}\text { CAT } \\
\text { No. }\end{array}$ & Area & Context & Type & $\begin{array}{l}\text { Raw- } \\
\text { material }\end{array}$ & $\begin{array}{c}\mathbf{L} \\
(\mathbf{m m})\end{array}$ & $\begin{array}{c}\mathrm{W} \\
(\mathbf{m m})\end{array}$ & $\begin{array}{c}\text { Th } \\
(\mathbf{m m})\end{array}$ & Comments \\
\hline 25 & $\begin{array}{l}\text { North- } \\
\text { west }\end{array}$ & 14 & $\begin{array}{l}\text { Short end- } \\
\text { scraper flake }\end{array}$ & Chert & 25.00 & 16.00 & 9.00 & $\begin{array}{l}\text { Due to a hidden plane-of- } \\
\text { weakness, the scraper split } \\
\text { roughly along the central long- } \\
\text { axis. The scraper-edge (half of } \\
\text { which survives) is convex, steep } \\
\text { and denticulated. }\end{array}$ \\
\hline 26 & $\begin{array}{l}\text { North- } \\
\text { west }\end{array}$ & $\mathrm{u} / \mathrm{s}$ & $\begin{array}{l}\text { Blade with } \\
\text { edge-retouch }\end{array}$ & Pitchstone & 22.00 & 14.00 & 4.00 & $\begin{array}{l}\text { Some of the retouch appears to } \\
\text { be deliberate modification, some } \\
\text { appear to be use-wear, and some } \\
\text { (unpatinated) may be post-depo- } \\
\text { sitional damage. }\end{array}$ \\
\hline 27 & $\begin{array}{l}\text { North- } \\
\text { west }\end{array}$ & $\mathrm{u} / \mathrm{s}$ & Flake & Quartz & 23.00 & 18.00 & 5.00 & \\
\hline 28 & $\begin{array}{l}\text { North- } \\
\text { west }\end{array}$ & $\mathrm{u} / \mathrm{s}$ & $\begin{array}{l}\text { Denticulated } \\
\text { flake }\end{array}$ & Quartz & 34.00 & 26.00 & 12.00 & $\begin{array}{l}\text { Three or four adjacent notches } \\
\text { at the distal end. The chords of } \\
\text { the notches are approximately } \\
6-8 \mathrm{~mm} \text {. }\end{array}$ \\
\hline 29 & West & 55 & $\begin{array}{l}\text { Microblade with } \\
\text { edge-retouch }\end{array}$ & Flint & 12.00 & 7.00 & 1.00 & A ‘microlith-related' implement. \\
\hline 30 & West & 97 & Chip & $\begin{array}{l}\text { Rock } \\
\text { crystal }\end{array}$ & & & & \\
\hline 31 & West & 97 & Chip & Quartz & & & & \\
\hline 32 & West & 114 & Flake & Flint & 11.00 & 6.00 & 1.00 & $\begin{array}{l}\text { Exotic flint, probably from } \\
\text { Yorkshire. }\end{array}$ \\
\hline 33 & West & 114 & Flake & Flint & 4.00 & 11.00 & 2.00 & $\begin{array}{l}\text { Exotic flint, probably from } \\
\text { Yorkshire. }\end{array}$ \\
\hline 34 & West & 125 & Chip & Flint & & & & \\
\hline 35 & West & 142 & Chip & Quartz & & & & \\
\hline 36 & West & 164 & Chip & Quartz & & & & \\
\hline 37 & $\begin{array}{l}\text { North- } \\
\text { west }\end{array}$ & 418 & Chip & $\begin{array}{l}\text { Rock } \\
\text { crystal }\end{array}$ & & & & \\
\hline 38 & $\begin{array}{l}\text { North- } \\
\text { west }\end{array}$ & 360 & Chip & Quartz & & & & \\
\hline 39 & $\begin{array}{l}\text { North- } \\
\text { west }\end{array}$ & 358 & Chip & Quartz & & & & \\
\hline 40 & $\begin{array}{l}\text { North- } \\
\text { west }\end{array}$ & 395 & Chip & Quartz & & & & \\
\hline 41 & $\begin{array}{l}\text { North- } \\
\text { west }\end{array}$ & 70 & Flake & Quartz & 14.00 & 9.00 & 7.00 & \\
\hline 42 & $\begin{array}{l}\text { North- } \\
\text { west }\end{array}$ & 100 & Chip & Quartz & & & & \\
\hline 43 & $\begin{array}{l}\text { North- } \\
\text { west }\end{array}$ & 263 & Flake & Quartz & 24.00 & 12.00 & 11.00 & \\
\hline 44 & $\begin{array}{l}\text { North- } \\
\text { west }\end{array}$ & 263 & Flake & Quartz & 13.00 & 12.00 & 3.00 & \\
\hline 45 & $\begin{array}{l}\text { North- } \\
\text { west }\end{array}$ & 263 & Flake & Quartz & 14.00 & 4.00 & 2.00 & \\
\hline 46 & $\begin{array}{l}\text { North- } \\
\text { west }\end{array}$ & 263 & Chip & Quartz & & & & \\
\hline 47 & $\begin{array}{l}\text { North- } \\
\text { west }\end{array}$ & 295 & Chip & Quartz & & & & \\
\hline 48 & Central & 52 & Chip & Flint & & & & $\begin{array}{l}\text { Exotic flint, probably from } \\
\text { Yorkshire. }\end{array}$ \\
\hline 49 & Central & 292 & $\begin{array}{l}\text { Chunk/indet. } \\
\text { piece }\end{array}$ & Flint & 17.00 & 9.00 & 10.00 & \\
\hline
\end{tabular}




\begin{tabular}{|c|c|c|c|c|c|c|c|c|}
\hline $\begin{array}{l}\text { CAT } \\
\text { No. }\end{array}$ & Area & Context & Type & $\begin{array}{l}\text { Raw- } \\
\text { material }\end{array}$ & $\underset{(\mathbf{m m})}{\mathbf{L}}$ & $\underset{(\mathbf{m m})}{\mathbf{W}}$ & $\underset{(\mathbf{m m})}{\mathbf{T h}}$ & Comments \\
\hline 50 & Central & 140 & Flake & Flint & 11.00 & 10.00 & 3.00 & $\begin{array}{l}\text { Probably exotic flint from } \\
\text { Yorkshire. }\end{array}$ \\
\hline 51 & Central & 296 & Flake & Quartz & 23.00 & 18.00 & 6.00 & \\
\hline 52 & East & 39005 & Chip & Flint & & & & \\
\hline 53 & East & 39007 & Chip & Flint & & & & \\
\hline 54 & East & 39007 & Chip & Flint & & & & \\
\hline 55 & East & 39007 & Chip & Flint & & & & \\
\hline 56 & East & 39007 & Chip & Flint & & & & \\
\hline 57 & East & 39007 & Chip & Flint & & & & \\
\hline 58 & East & 39007 & Chip & Flint & & & & \\
\hline 59 & East & 39007 & Chip & Flint & & & & \\
\hline 60 & East & 39007 & Chip & Flint & & & & \\
\hline 61 & East & 39007 & Chip & Flint & & & & \\
\hline 62 & East & 39007 & Chip & Flint & & & & \\
\hline 63 & East & 39007 & Chip & Flint & & & & \\
\hline 64 & East & 39007 & Microblade & Flint & 5.00 & 4.00 & 1.00 & \\
\hline 65 & East & 39007 & Microblade & Flint & 6.00 & 4.00 & 1.00 & \\
\hline 66 & East & 39007 & Microblade & Flint & 6.00 & 4.00 & 1.00 & \\
\hline 67 & East & 39007 & Microblade & Flint & 3.00 & 4.00 & 1.00 & \\
\hline 68 & East & 39007 & Microblade & Flint & 7.00 & 4.00 & 1.00 & \\
\hline 69 & East & 39007 & Microblade & Flint & 8.00 & 5.00 & 1.00 & \\
\hline 70 & East & 39007 & Microblade & Flint & 9.00 & 3.00 & 1.00 & \\
\hline 71 & East & 39007 & Microblade & Flint & 13.00 & 6.00 & 2.00 & \\
\hline 72 & East & 39007 & Microblade & Flint & 9.00 & 6.00 & 1.00 & \\
\hline 73 & $\begin{array}{l}\text { North- } \\
\text { west }\end{array}$ & 55010 & Chip & Flint & & & & \\
\hline 74 & $\begin{array}{l}\text { North- } \\
\text { west }\end{array}$ & 55010 & Chip & Flint & & & & \\
\hline
\end{tabular}




\section{APPENDIX 7: BOTANICAL RESULTS FROM LAIGH NEWTON WEST - STRUCTURE A}

\begin{tabular}{|c|c|c|c|c|c|c|c|c|c|c|c|}
\hline & $\begin{array}{l}\text { Excavation } \\
\text { code }\end{array}$ & 2490 & 2490 & 2490 & 2490 & 2490 & 2490 & 2490 & 2490 & 2490 & 2490 \\
\hline & Context & 128 & 152 & 153 & 155 & 157 & 159 & 164 & 177 & 178 & 179 \\
\hline & Sample & 43 & 61 & 57 & 58 & 62 & 63 & 67 & 72 & 73, SF25 & 74 \\
\hline & Description & 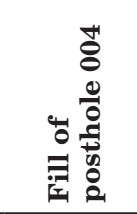 & 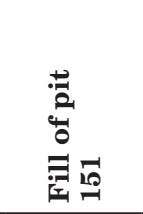 & 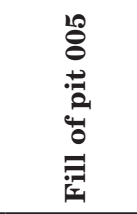 & 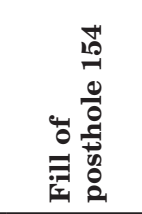 & 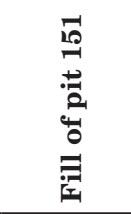 & 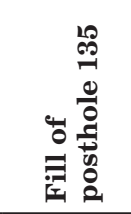 & 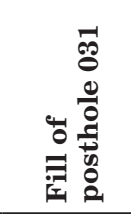 & 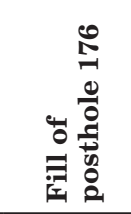 & 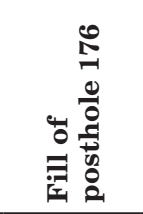 & 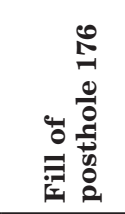 \\
\hline Modern & & + & + & ++ & ++ & + & + & ++ & + & ++ & + \\
\hline $\begin{array}{l}\text { Volume of } \\
\text { charcoal } \\
>2 \mathrm{~mm}\end{array}$ & & $<2.5 \mathrm{ml}$ & $<2.5 \mathrm{ml}$ & $105 \mathrm{ml}$ & $25 \mathrm{ml}$ & $<<2.5 \mathrm{ml}$ & $<<2.5 \mathrm{ml}$ & $5 \mathrm{ml}$ & $<<2.5 \mathrm{ml}$ & $<2.5 \mathrm{ml}$ & $<2.5 \mathrm{ml}$ \\
\hline $\begin{array}{l}\text { Volume of } \\
\text { charcoal } \\
>4 \mathrm{~mm}\end{array}$ & & $5 \mathrm{ml}$ & $<2.5 \mathrm{ml}$ & $60 \mathrm{ml}$ & $10 \mathrm{ml}$ & - & $<<2.5 \mathrm{ml}$ & $2.5 \mathrm{ml}$ & $<<2.5 \mathrm{ml}$ & $5 \mathrm{ml}$ & $<2.5 \mathrm{ml}$ \\
\hline $\begin{array}{l}\text { Extrapolated } \\
\text { results }\end{array}$ & & & & $*$ & & & & & & & \\
\hline \multicolumn{12}{|l|}{ Charcoal } \\
\hline Alnus & alder & $2(0.06 g)$ & & $\begin{array}{l}58 \\
(10.44 \mathrm{~g})\end{array}$ & $\begin{array}{l}23 \\
(1.08 g)\end{array}$ & & & & & & \\
\hline Betula & birch & & $1(0.02 g)$ & $\begin{array}{l}28 \\
(2.76 \mathrm{~g})\end{array}$ & $\begin{array}{l}13 \\
(0.55 \mathrm{~g})\end{array}$ & & & & & & \\
\hline Corylus & hazel & $4(0.29 g)$ & & $4(0.28 \mathrm{~g})$ & $4(0.25 \mathrm{~g})$ & & $2(0.07 \mathrm{~g})$ & $3(0.07 g)$ & & $1(0.37 g)$ & $4(0.64 \mathrm{~g})$ \\
\hline Quercus & oak & & $1(0.02 \mathrm{~g})$ & & & & & $5(0.10 \mathrm{~g})$ & $2(0.2 \mathrm{~g})$ & $2(0.04 \mathrm{~g})$ & $\begin{array}{l}40 \\
(0.52 \mathrm{~g})\end{array}$ \\
\hline Salix & willow & $1(0.02 \mathrm{~g})$ & & & $5(0.26 g)$ & & & & & & $4(0.08 g)$ \\
\hline $\begin{array}{l}\text { Indet. } \\
\text { charcoal }\end{array}$ & $\begin{array}{l}\text { indeter- } \\
\text { minate } \\
\text { charcoal }\end{array}$ & & & & & & & $1(0.07 \mathrm{~g})$ & & & \\
\hline \multicolumn{12}{|l|}{$\begin{array}{l}\text { Mineralised } \\
\text { wood }\end{array}$} \\
\hline \multicolumn{12}{|c|}{ Cereals (carb) } \\
\hline Avena sp. & oat & & & 104 & 16 & & & 1 & & & \\
\hline cf Avena sp. & cf oat & & 1 & 122 & 32 & & & 2 & & & \\
\hline $\begin{array}{l}\text { Hordeum } \\
\text { vulgare sl. }\end{array}$ & $\begin{array}{l}\text { six-row } \\
\text { barley }\end{array}$ & & & 6 & & & & & & & \\
\hline $\begin{array}{l}\text { cf Hordeum } \\
\text { vulgare sl. }\end{array}$ & $\begin{array}{l}\text { cf six-row } \\
\text { barley }\end{array}$ & & & 3 & & & & & & & \\
\hline Cereal indet. & $\begin{array}{l}\text { cereal inde- } \\
\text { terminate }\end{array}$ & & & 78 & & & & & & & \\
\hline \multicolumn{12}{|c|}{ Seeds etc (carb) } \\
\hline $\begin{array}{l}\text { Corylus } \\
\text { avellana } \\
\text { nutshell frags }\end{array}$ & $\begin{array}{l}\text { hazel } \\
\text { nutshell } \\
\text { frags }\end{array}$ & $9(0.04 \mathrm{~g})$ & & $3(0.05 \mathrm{~g})$ & & $3(0.04 \mathrm{~g})$ & & $\begin{array}{l}1 \\
(<0.01 \mathrm{~g})\end{array}$ & & & $\begin{array}{l}1 \\
(<0.01 \mathrm{~g})\end{array}$ \\
\hline $\begin{array}{l}\text { Lapsana } \\
\text { communis }\end{array}$ & nipplewort & & & 2 & & & & & & & \\
\hline $\begin{array}{l}\text { Persicaria } \\
\text { maculosa }\end{array}$ & redshank & & & 5 & & & & & & & \\
\hline $\begin{array}{l}\text { Spergula } \\
\text { arvensis }\end{array}$ & corn spurrey & & & 1 & & & & & & & \\
\hline
\end{tabular}




\begin{tabular}{|c|c|c|c|c|c|c|c|c|c|c|c|}
\hline & $\begin{array}{l}\text { Excavation } \\
\text { code }\end{array}$ & 2490 & 2490 & 2490 & 2490 & 2490 & 2490 & 2490 & 2490 & 2490 & 2490 \\
\hline & Context & 181 & 191 & 205 & $209 / 214$ & 256 & 257 & 261 & 274 & 275 & 310 \\
\hline & Sample & 77 & 79 & 96 & 100 & 105 & 106 & 108 & $\begin{array}{c}\text { 120, } \\
\text { SF57 }\end{array}$ & $\begin{array}{l}\text { 121, } \\
\text { SF56 }\end{array}$ & 147 \\
\hline & Description & 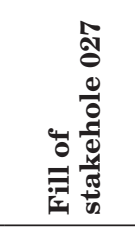 & 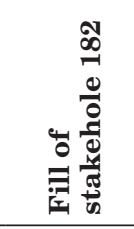 & 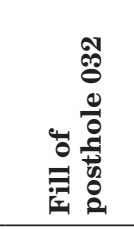 & 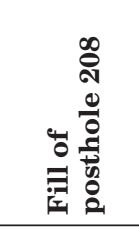 & 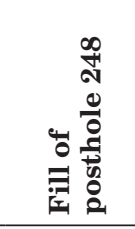 & 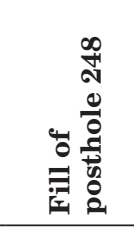 & 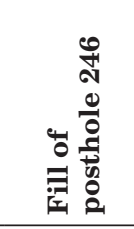 & 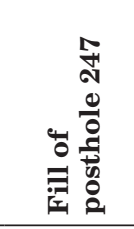 & 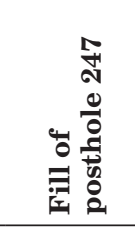 & 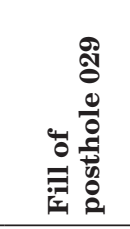 \\
\hline Modern & & + & + & + & + & + & + & + & + & + & + \\
\hline $\begin{array}{l}\text { Volume of } \\
\text { charcoal } \\
>2 \mathrm{~mm}\end{array}$ & & $<2.5 \mathrm{ml}$ & $<2.5 \mathrm{ml}$ & $15 \mathrm{ml}$ & $5 \mathrm{ml}$ & $<2.5 \mathrm{ml}$ & $2.5 \mathrm{ml}$ & $2.5 \mathrm{ml}$ & - & $<2.5 \mathrm{ml}$ & $<2.5 \mathrm{ml}$ \\
\hline $\begin{array}{l}\text { Extrapolated } \\
\text { results }\end{array}$ & & & & $*$ & & & & & & & \\
\hline \multicolumn{12}{|l|}{ Charcoal } \\
\hline Alnus & alder & & $1(0.01 g)$ & $\begin{array}{l}42 \\
(1.86 \mathrm{~g})\end{array}$ & $4(0.07 g)$ & & $2(0.09 g)$ & & & & \\
\hline Betula & birch & & & $6(0.26 g)$ & & & & & & & \\
\hline Corylus & hazel & $1(0.20 \mathrm{~g})$ & & $6(0.24 \mathrm{~g})$ & $3(0.04 \mathrm{~g})$ & & $4(0.26 g)$ & $1(0.03 g)$ & & & \\
\hline Quercus & oak & & $1(0.01 \mathrm{~g})$ & & & $2(0.01 g)$ & $7(0.21 \mathrm{~g})$ & $1(0.05 \mathrm{~g})$ & & & \\
\hline Salix & willow & & & & & & & & & & $2(0.08 g)$ \\
\hline $\begin{array}{l}\text { Indet. } \\
\text { charcoal }\end{array}$ & $\begin{array}{l}\text { indeter- } \\
\text { minate } \\
\text { charcoal }\end{array}$ & & & & & & & & & & \\
\hline \multicolumn{12}{|l|}{ Cereals (carb) } \\
\hline Avena sp. & oat & & & & 3 & & & & & & \\
\hline cf Avena sp. & cf oat & & 1 & & 4 & 1 & 3 & & & & \\
\hline $\begin{array}{l}\text { Hordeum } \\
\text { vulgare sl. }\end{array}$ & $\begin{array}{l}\text { six-row } \\
\text { barley }\end{array}$ & & & & & & & & & & \\
\hline $\begin{array}{l}\text { cf Hordeum } \\
\text { vulgare sl. }\end{array}$ & $\begin{array}{l}\text { cf six-row } \\
\text { barley }\end{array}$ & & & & & & & & & & \\
\hline Cereal indet. & $\begin{array}{l}\text { cereal inde- } \\
\text { terminate }\end{array}$ & & & & & & & & & & \\
\hline \multicolumn{12}{|c|}{ Seeds etc (carb) } \\
\hline $\begin{array}{l}\text { Corylus } \\
\text { avellana } \\
\text { nutshell frags }\end{array}$ & $\begin{array}{l}\text { hazel } \\
\text { nutshell } \\
\text { frags }\end{array}$ & & & $5(0.06 g)$ & & & $\begin{array}{l}1 \\
(<0.01 \mathrm{~g})\end{array}$ & $\begin{array}{l}33 \\
(0.20 \mathrm{~g})\end{array}$ & & $5(0.12 g)$ & \\
\hline $\begin{array}{l}\text { Lapsana } \\
\text { communis }\end{array}$ & nipplewort & & & & & & 1 & & & & \\
\hline $\begin{array}{l}\text { Persicaria } \\
\text { maculosa }\end{array}$ & redshank & & & & & & & & & & \\
\hline $\begin{array}{l}\text { Spergula } \\
\text { arvensis }\end{array}$ & corn spurrey & & & & & & & & & & \\
\hline
\end{tabular}




\section{APPENDIX 8: BOTANICAL RESULTS FROM LAIGH NEWTON WEST - STRUCTURE B}

\begin{tabular}{|c|c|c|c|c|c|c|}
\hline & $\begin{array}{l}\text { Excavation } \\
\text { code }\end{array}$ & 2490 & 2490 & 2490 & 2490 & 2490 \\
\hline & Context & 180 & 202 & 284 & 285 & 299 \\
\hline & Sample & 71 & 93 & 129 & 130 & 143 \\
\hline & Description & $\begin{array}{l}\text { Fill of } \\
\text { posthole } 050\end{array}$ & $\begin{array}{l}\text { Fill of } \\
\text { pit } 051\end{array}$ & $\begin{array}{l}\text { Fill of } \\
\text { posthole } 048\end{array}$ & $\begin{array}{l}\text { Fill of } \\
\text { posthole } 049\end{array}$ & $\begin{array}{l}\text { Fill of } \\
\text { posthole } 052\end{array}$ \\
\hline Modern & & + & + & + & + & ++ \\
\hline $\begin{array}{l}\text { Volume of charcoal } \\
>2 \mathrm{~mm}\end{array}$ & & $2.5 \mathrm{ml}$ & $<2.5 \mathrm{ml}$ & $<<2.5 \mathrm{ml}$ & $<<2.5 \mathrm{ml}$ & $10 \mathrm{ml}$ \\
\hline $\begin{array}{l}\text { Volume of charcoal } \\
>4 \mathrm{~mm}\end{array}$ & & $<2.5 \mathrm{ml}$ & $<2.5 \mathrm{ml}$ & $<2.5 \mathrm{ml}$ & - & $15 \mathrm{ml}$ \\
\hline Extrapolated results & & & & & & $*$ \\
\hline \multicolumn{7}{|l|}{ Charcoal } \\
\hline Alnus & alder & & $1(0.02 \mathrm{~g})$ & $1(0.14 \mathrm{~g})$ & & $21(0.66)$ \\
\hline Betula & birch & & & & & $3(0.26 \mathrm{~g})$ \\
\hline Ericales & heather type & & $1(0.02 \mathrm{~g})$ & & & \\
\hline Corylus & hazel & $1(0.04 \mathrm{~g})$ & & & & \\
\hline Quercus & oak & & $2(0.06 g)$ & & & \\
\hline Salix & willow & $1(0.03 g)$ & & & & \\
\hline \multicolumn{7}{|l|}{ Seeds etc (carb) } \\
\hline $\begin{array}{l}\text { Corylus avellana } \\
\text { nutshell frags }\end{array}$ & $\begin{array}{l}\text { hazel nutshell } \\
\text { frags }\end{array}$ & $7(0.11 \mathrm{~g})$ & & & $1(<0.01 \mathrm{~g})$ & \\
\hline
\end{tabular}




\section{APPENDIX 9: BOTANICAL RESULTS FROM LAIGH NEWTON WEST - PIT 99 AND SURROUNDING POSTHOLES}

\begin{tabular}{|c|c|c|c|c|c|c|c|c|}
\hline & $\begin{array}{l}\text { Excavation } \\
\text { code }\end{array}$ & 2490 & 2490 & 2490 & 2490 & 2490 & 2490 & 2490 \\
\hline & Context & 7 & 8 & 9 & 10 & 13 & 14 & 25 \\
\hline & Sample & 4 & 3 & 2 & 1 & 12 & 13 & 14 \\
\hline & Description & $\begin{array}{l}\text { Fill of } \\
\text { posthole } \\
080\end{array}$ & $\begin{array}{l}\text { Fill of } \\
\text { posthole } \\
081\end{array}$ & $\begin{array}{l}\text { Fill of } \\
\text { posthole } \\
082\end{array}$ & $\begin{array}{l}\text { Fill of } \\
\text { posthole } \\
083\end{array}$ & $\begin{array}{l}\text { Fill of } \\
\text { posthole } \\
086\end{array}$ & $\begin{array}{l}\text { Fill of } \\
\text { posthole } \\
087\end{array}$ & $\begin{array}{l}\text { Fill of } \\
\text { posthole } \\
090\end{array}$ \\
\hline Modern & & + & + & + & + & + & + & + \\
\hline $\begin{array}{l}\text { Volume of } \\
\text { charcoal }>2 \mathrm{~mm}\end{array}$ & & $<2.5 \mathrm{ml}$ & $<<2.5 \mathrm{ml}$ & $5 \mathrm{ml}$ & $2.5 \mathrm{ml}$ & $2.5 \mathrm{ml}$ & $10 \mathrm{ml}$ & $<2.5 \mathrm{ml}$ \\
\hline $\begin{array}{l}\text { Volume of } \\
\text { charcoal }>4 \mathrm{~mm}\end{array}$ & & $2.5 \mathrm{ml}$ & $<<2.5 \mathrm{ml}$ & $2.5 \mathrm{ml}$ & $5 \mathrm{ml}$ & $2.5 \mathrm{ml}$ & $10 \mathrm{ml}$ & $<2.5 \mathrm{ml}$ \\
\hline \multicolumn{9}{|l|}{$\begin{array}{l}\text { Extrapolated } \\
\text { results }\end{array}$} \\
\hline \multicolumn{9}{|l|}{ Charcoal } \\
\hline Alnus & alder & & & $2(0.04 \mathrm{~g})$ & $1(0.10 \mathrm{~g})$ & $3(0.11 \mathrm{~g})$ & & $1(0.04 g)$ \\
\hline Betula & birch & & & & & & & $1(0.03 g)$ \\
\hline Corylus & hazel & & & & & $1(0.08 g)$ & & $1(0.02 \mathrm{~g})$ \\
\hline Quercus & oak & $8(0.19 g)$ & $1(0.02 \mathrm{~g})$ & & $16(0.42 \mathrm{~g})$ & $3(0.05 g)$ & $17(0.51 \mathrm{~g})$ & \\
\hline Salix & willow & & & $1(0.22 \mathrm{~g})$ & & $1(0.05 \mathrm{~g})$ & $1(0.25 \mathrm{~g})$ & \\
\hline \multicolumn{9}{|l|}{ Cereals (carb) } \\
\hline cf Avena sp. & cf oat & & & 1 & & & 2 & \\
\hline Cereal indet. & $\begin{array}{l}\text { cereal } \\
\text { indeterminate }\end{array}$ & & & & 1 & 1 & & \\
\hline \multicolumn{9}{|l|}{ Seeds etc (carb) } \\
\hline $\begin{array}{l}\text { Corylus avellana } \\
\text { nutshell frags }\end{array}$ & $\begin{array}{l}\text { hazel nutshell } \\
\text { frags }\end{array}$ & $1(<0.01 \mathrm{~g})$ & & & $5(0.07 \mathrm{~g})$ & & & $3(0.04 \mathrm{~g})$ \\
\hline
\end{tabular}




\section{APPENDIX 10: BOTANICAL RESULTS FROM LAIGH NEWTON WEST - PIT 40, SEGMENTED LINEAR FEATURE POSSIBLE ROUNDHOUSE}

\begin{tabular}{|c|c|c|c|c|c|c|c|}
\hline & $\begin{array}{l}\text { Excavation } \\
\text { code }\end{array}$ & 2490 & 2490 & 2490 & 2490 & 2490 & 2490 \\
\hline & Context & 114 & 115 & 116 & 139 & 129 & 156 \\
\hline & Sample & 35, SF58 & 36 & 37, SF59 & 49 & 44 & 59,60 \\
\hline & Description & $\begin{array}{l}\text { Fill of pit } \\
040\end{array}$ & $\begin{array}{l}\text { Fill of pit } \\
040\end{array}$ & $\begin{array}{l}\text { Fill of pit } \\
040\end{array}$ & $\begin{array}{l}\text { Fill of linear } \\
\text { feature } 126\end{array}$ & $\begin{array}{l}\text { Fill of } \\
\text { posthole } 038\end{array}$ & $\begin{array}{l}\text { Fill of } \\
\text { posthole } 035\end{array}$ \\
\hline Modern & & + & + & + & + & + & + \\
\hline $\begin{array}{l}\text { Volume of } \\
\text { charcoal } \\
>2 \mathrm{~mm}\end{array}$ & & $75 \mathrm{ml}$ & $2.5 \mathrm{ml}$ & $20 \mathrm{ml}$ & $<2.5 \mathrm{ml}$ & $<<2.5 \mathrm{ml}$ & $<2.5 \mathrm{ml}$ \\
\hline $\begin{array}{l}\text { Volume of } \\
\text { charcoal } \\
>4 \mathrm{~mm}\end{array}$ & & $150 \mathrm{ml}$ & $2.5 \mathrm{ml}$ & $45 \mathrm{ml}$ & $<<2.5 \mathrm{ml}$ & - & $2.5 \mathrm{ml}$ \\
\hline $\begin{array}{l}\text { Extrapolated } \\
\text { results }\end{array}$ & & $*$ & & & & & \\
\hline \multicolumn{8}{|l|}{ Charcoal } \\
\hline Alnus & alder & $58(7.46 g)$ & & 35 (2.26g) & $1(0.03 g)$ & & $2(0.18 g)$ \\
\hline Betula & birch & $36(2.51 \mathrm{~g})$ & $6(0.28 \mathrm{~g})$ & $11(0.79 g)$ & & & $1(0.04 \mathrm{~g})$ \\
\hline Corylus & hazel & $52(20.21 \mathrm{~g})$ & $1(0.05 \mathrm{~g})$ & 7 (3.05g) & & & \\
\hline Quercus & oak & $30(1.04 \mathrm{~g})$ & & 67 (2.78g) & $1(0.04 \mathrm{~g})$ & & \\
\hline Salix & willow & & & & & & \\
\hline \multicolumn{8}{|c|}{ Cereals (carb) } \\
\hline cf Avena sp. & cf oat & & & & & & \\
\hline $\begin{array}{l}\text { Hordeum } \\
\text { vulgare sl. }\end{array}$ & $\begin{array}{l}\text { six-row } \\
\text { barley }\end{array}$ & & & & & & \\
\hline \multicolumn{8}{|c|}{ Seeds etc (carb) } \\
\hline $\begin{array}{l}\text { Corylus } \\
\text { avellana } \\
\text { nutshell frags }\end{array}$ & $\begin{array}{l}\text { hazel } \\
\text { nutshell frags }\end{array}$ & $1(0.03 g)$ & $5(0.06 \mathrm{~g})$ & & & $1(0.01 \mathrm{~g})$ & \\
\hline $\begin{array}{l}\text { Rubus idaeus } \\
\text { / fruticosus }\end{array}$ & $\begin{array}{l}\text { raspberry / } \\
\text { bramble }\end{array}$ & & 1 & & & & 1 \\
\hline
\end{tabular}




\begin{tabular}{|c|c|c|c|c|c|c|c|}
\hline & $\begin{array}{l}\text { Excavation } \\
\text { code }\end{array}$ & 2490 & 2490 & 2490 & 2490 & 2490 & 2490 \\
\hline & Context & 160 & 198 & 213 & 218 & 165 & 168 \\
\hline & Sample & 64 & 89 & 99 & 109 & 68 & 69 \\
\hline & Description & $\begin{array}{l}\text { Fill of } \\
\text { posthole } 034\end{array}$ & $\begin{array}{l}\text { Fill of } \\
\text { posthole } 185\end{array}$ & $\begin{array}{l}\text { Fill of } \\
\text { posthole } 186\end{array}$ & $\begin{array}{l}\text { Fill of } \\
\text { posthole } 042\end{array}$ & $\begin{array}{l}\text { Fill of } \\
\text { posthole } 041\end{array}$ & $\begin{array}{l}\text { Fill of pit } \\
045\end{array}$ \\
\hline Modern & & + & + & + & + & + & ++ \\
\hline $\begin{array}{l}\text { Volume of } \\
\text { charcoal } \\
>2 \mathrm{~mm}\end{array}$ & & $<<2.5 \mathrm{ml}$ & $<2.5 \mathrm{ml}$ & $<<2.5 \mathrm{ml}$ & $2.5 \mathrm{ml}$ & $<<2.5 \mathrm{ml}$ & $<<2.5 \mathrm{ml}$ \\
\hline $\begin{array}{l}\text { Volume of } \\
\text { charcoal } \\
>4 \mathrm{~mm}\end{array}$ & & - & $<2.5 \mathrm{ml}$ & - & $2.5 \mathrm{ml}$ & $<2.5 \mathrm{ml}$ & $<<2.5 \mathrm{ml}$ \\
\hline \multicolumn{8}{|l|}{$\begin{array}{l}\text { Extrapolated } \\
\text { results }\end{array}$} \\
\hline \multicolumn{8}{|l|}{ Charcoal } \\
\hline Alnus & alder & & $2(0.06 \mathrm{~g})$ & & $3(0.22 \mathrm{~g})$ & & \\
\hline Betula & birch & & & & & & \\
\hline Corylus & hazel & & & & & & $1(0.02 \mathrm{~g})$ \\
\hline Quercus & oak & & $2(0.05 \mathrm{~g})$ & & $5(0.08 g)$ & $1(0.02 \mathrm{~g})$ & \\
\hline Salix & willow & & & & & $1(0.02 \mathrm{~g})$ & \\
\hline \multicolumn{8}{|c|}{ Cereals (carb) } \\
\hline cf Avena sp. & cf oat & & & & 1 & & \\
\hline $\begin{array}{l}\text { Hordeum } \\
\text { vulgare sl. }\end{array}$ & $\begin{array}{l}\text { six-row } \\
\text { barley }\end{array}$ & & & & 1 & & \\
\hline \multicolumn{8}{|c|}{ Seeds etc (carb) } \\
\hline $\begin{array}{l}\text { Corylus } \\
\text { avellana } \\
\text { nutshell frags }\end{array}$ & $\begin{array}{l}\text { hazel } \\
\text { nutshell } \\
\text { frags }\end{array}$ & $1(0.02 \mathrm{~g})$ & & $1(<0.01 \mathrm{~g})$ & $4(0.06 g)$ & & \\
\hline $\begin{array}{l}\text { Rubus idaeus } \\
\text { / fruticosus }\end{array}$ & $\begin{array}{l}\text { raspberry / } \\
\text { bramble }\end{array}$ & & & & & & \\
\hline
\end{tabular}




\section{APPENDIX 11: BOTANICAL RESULTS FROM LAIGH NEWTON WEST - WESTERN PITS}

\begin{tabular}{|c|c|c|c|c|c|c|c|c|c|}
\hline & $\begin{array}{l}\text { Excavation } \\
\text { code }\end{array}$ & 2490 & 2490 & 2490 & 2490 & 2490 & 2490 & 2490 & 2490 \\
\hline & Context & 258 & 277 & 278 & 282 & 298 & 305 & 307 & 308 \\
\hline & Sample & $\begin{array}{l}\text { SF50, } \\
\text { SF67 }\end{array}$ & 123 & $124(121)$ & 127 & 142 & 148 & 149 & 150 \\
\hline & Description & $\begin{array}{l}\text { Fill of pit } \\
250\end{array}$ & $\begin{array}{l}\text { Fill of pit } \\
250\end{array}$ & $\begin{array}{l}\text { Fill of pit } \\
250\end{array}$ & $\begin{array}{l}\text { Fill of pit } \\
251\end{array}$ & $\begin{array}{l}\text { Fill of pit } \\
061\end{array}$ & $\begin{array}{l}\text { Fill of pit } \\
059\end{array}$ & $\begin{array}{l}\text { Fill of pit } \\
060\end{array}$ & $\begin{array}{l}\text { Fill of pit } \\
060\end{array}$ \\
\hline Modern & & - & + & + & + & + & + & + & + \\
\hline $\begin{array}{l}\text { Volume of } \\
\text { charcoal }>2 \mathrm{~mm}\end{array}$ & & - & $5 \mathrm{ml}$ & $10 \mathrm{ml}$ & $<2.5 \mathrm{ml}$ & $2.5 \mathrm{ml}$ & $10 \mathrm{ml}$ & $5 \mathrm{ml}$ & - \\
\hline $\begin{array}{l}\text { Volume of } \\
\text { charcoal }>4 \mathrm{~mm}\end{array}$ & & $45 \mathrm{ml}$ & $5 \mathrm{ml}$ & $65 \mathrm{ml}$ & $<2.5 \mathrm{ml}$ & $2.5 \mathrm{ml}$ & $2.5 \mathrm{ml}$ & $5 \mathrm{ml}$ & $<<2.5 \mathrm{ml}$ \\
\hline $\begin{array}{l}\text { Extrapolated } \\
\text { results }\end{array}$ & & & & $*$ & & & & & \\
\hline \multicolumn{10}{|l|}{ Charcoal } \\
\hline Alnus & alder & $10(2.11 \mathrm{~g})$ & $7(0.15 \mathrm{~g})$ & $84(4.44 \mathrm{~g})$ & & & & & \\
\hline Betula & birch & $9(3.58 g)$ & $2(0.21 \mathrm{~g})$ & $18(0.90 \mathrm{~g})$ & $1(0.04 \mathrm{~g})$ & & $1(0.04 \mathrm{~g})$ & & \\
\hline Corylus & hazel & 7 (2.73g) & $2(0.22 \mathrm{~g})$ & $27(1.62 \mathrm{~g})$ & & & & & \\
\hline Ericales & heather type & & & & $1(<0.01 \mathrm{~g})$ & & & & \\
\hline Quercus & oak & & & $3(0.18 g)$ & & $14(0.25 \mathrm{~g})$ & $8(0.21 \mathrm{~g})$ & $14(0.71 \mathrm{~g})$ & $1(0.02 \mathrm{~g})$ \\
\hline Salix & willow & & & $15(0.84 \mathrm{~g})$ & & & & $1(0.05 \mathrm{~g})$ & \\
\hline Indet. charcoal & $\begin{array}{l}\text { indeterminate } \\
\text { charcoal }\end{array}$ & & & $12(1.32 \mathrm{~g})$ & & & & & \\
\hline \multicolumn{10}{|l|}{ Seeds etc (carb) } \\
\hline $\begin{array}{l}\text { Corylus avellana } \\
\text { nutshell frags }\end{array}$ & $\begin{array}{l}\text { hazel nutshell } \\
\text { frags }\end{array}$ & & & & $1(0.03 g)$ & $1(0.02 \mathrm{~g})$ & & $7(0.08 g)$ & $2(0.04 \mathrm{~g})$ \\
\hline
\end{tabular}




\section{APPENDIX 12: BOTANICAL RESULTS FROM LAIGH NEWTON WEST - MISCELLANEOUS}

\begin{tabular}{|c|c|c|c|c|c|c|c|c|c|c|}
\hline & $\begin{array}{l}\text { Excavation } \\
\text { code }\end{array}$ & 2490 & 2490 & 2490 & 2490 & 2490 & 2490 & 2490 & 2490 & 2490 \\
\hline & Context & 55 & 68 & 69 & 79 & 96 & 97 & 102 & 103 & 149 \\
\hline & Sample & $\begin{array}{l}6,7,8,9 \\
\text { SF48 }\end{array}$ & 56 & 53 & 76 & 30 & 21 & 24 & 28 & 55 \\
\hline & Description & $\begin{array}{l}\text { Fill of } \\
\text { tree- } \\
\text { throw } \\
\mathbf{0 9 5}\end{array}$ & $\begin{array}{l}\text { Fill of pit } \\
150\end{array}$ & $\begin{array}{l}\text { Fill of pit } \\
147\end{array}$ & $\begin{array}{l}\text { Fill of } \\
\text { posthole } \\
174\end{array}$ & $\begin{array}{l}\text { Fill of } \\
\text { tree- } \\
\text { throw } \\
\mathbf{0 9 5}\end{array}$ & $\begin{array}{l}\text { Fill of } \\
\text { feature } \\
075\end{array}$ & $\begin{array}{l}\text { Fill of } \\
\text { feature } \\
073\end{array}$ & $\begin{array}{l}\text { Fill of } \\
065\end{array}$ & $\begin{array}{l}\text { Fill of pit } \\
148\end{array}$ \\
\hline $\begin{array}{l}\text { Volume of } \\
\text { charcoal }>2 \mathrm{~mm}\end{array}$ & & $10 \mathrm{ml}$ & $2.5 \mathrm{ml}$ & $2.5 \mathrm{ml}$ & $<2.5 \mathrm{ml}$ & $<2.5 \mathrm{ml}$ & - & $<<2.5 \mathrm{ml}$ & $<<2.5 \mathrm{ml}$ & $<<2.5 \mathrm{ml}$ \\
\hline $\begin{array}{l}\text { Volume of } \\
\text { charcoal }>4 \mathrm{~mm}\end{array}$ & & $30 \mathrm{ml}$ & $<2.5 \mathrm{ml}$ & $2.5 \mathrm{ml}$ & $<2.5 \mathrm{ml}$ & $<2.5 \mathrm{ml}$ & - & $<<2.5 \mathrm{ml}$ & $<<2.5 \mathrm{ml}$ & $<<2.5 \mathrm{ml}$ \\
\hline \multicolumn{11}{|l|}{$\begin{array}{l}\text { Extrapolated } \\
\text { results }\end{array}$} \\
\hline Alnus & alder & & $3(0.07 \mathrm{~g})$ & & & & & & & \\
\hline Betula & birch & $3(0.08 g)$ & & & $1(0.02 \mathrm{~g})$ & & & & & $2(0.01 \mathrm{~g})$ \\
\hline Corylus & hazel & $21(0.37 \mathrm{~g})$ & $1(0.06 \mathrm{~g})$ & $10(0.22 \mathrm{~g})$ & & $3(0.12 \mathrm{~g})$ & & & $1(0.03 g)$ & \\
\hline Ericales & heather type & & & & $2(0.03 g)$ & & & & & \\
\hline Quercus & oak & $2(2.25 \mathrm{~g})$ & & & $1(0.03 g)$ & & & & & $1(0.01 \mathrm{~g})$ \\
\hline Salix & willow & $10(0.37 \mathrm{~g})$ & & & & & & $2(0.04 \mathrm{~g})$ & & $1(0.02 \mathrm{~g})$ \\
\hline $\begin{array}{l}\text { Indet. small } \\
\text { twigs }\end{array}$ & $\begin{array}{l}\text { indeterminate } \\
\text { small twigs }\end{array}$ & & & & $2(0.06 \mathrm{~g})$ & & & & & \\
\hline Indet. cinder & $\begin{array}{l}\text { indeterminate } \\
\text { cinder }\end{array}$ & & & & & & $+(2.10 \mathrm{~g})$ & & & \\
\hline $\begin{array}{l}\text { cf Hordeum } \\
\text { vulgare sl. }\end{array}$ & cf six-row barley & & & & & & & & & \\
\hline Cereal indet & $\begin{array}{l}\text { cereal } \\
\text { indeterminate }\end{array}$ & & & & 1 & & & & & \\
\hline \multicolumn{11}{|l|}{ Seeds etc (carb) } \\
\hline $\begin{array}{l}\text { Corylus avellana } \\
\text { nutshell frags }\end{array}$ & $\begin{array}{l}\text { hazel nutshell } \\
\text { frags }\end{array}$ & $1(0.03 g)$ & $2(0.01 \mathrm{~g})$ & $9(0.07 \mathrm{~g})$ & & & & & & \\
\hline
\end{tabular}




\begin{tabular}{|c|c|c|c|c|c|c|c|c|c|c|c|}
\hline 2490 & 2490 & 2490 & 2490 & 2490 & 2490 & 2490 & 2490 & 2490 & 2490 & 2490 & 2028 \\
\hline 199 & 200 & 283 & 279 & 263 & 264 & 266 & 267 & 273 & 286 & 293 & 61003 \\
\hline 91 & 92 & 128 & 125 & 111 & 112 & 115 & 116 & 119 & 131 & 138 & 17 \\
\hline $\begin{array}{l}\text { Fill of } \\
204\end{array}$ & $\begin{array}{l}\text { Fill of } \\
204\end{array}$ & $\begin{array}{l}\text { Fill of } \\
\text { posthole } \\
252\end{array}$ & $\begin{array}{l}\text { Fill of } \\
\text { posthole } \\
254\end{array}$ & $\begin{array}{l}\text { Fill of pit } \\
229\end{array}$ & $\begin{array}{l}\text { Fill of pit } \\
230\end{array}$ & $\begin{array}{l}\text { Fill of } \\
226\end{array}$ & $\begin{array}{l}\text { Fill of } \\
226\end{array}$ & $\begin{array}{l}\text { Fill of pit } \\
232\end{array}$ & $\begin{array}{l}\text { Fill of } \\
\text { feature } \\
219\end{array}$ & $\begin{array}{l}\text { Fill of } \\
\text { feature } \\
222\end{array}$ & $\begin{array}{l}\text { Fill of } \\
(61004) \\
\text { Burning }\end{array}$ \\
\hline+ & + & + & + & + & + & + & + & + & + & + & + \\
\hline$<2.5 \mathrm{ml}$ & $<<2.5 \mathrm{ml}$ & $<<2.5 \mathrm{ml}$ & $<<2.5 \mathrm{ml}$ & $5 \mathrm{ml}$ & $<<2.5 \mathrm{ml}$ & $12.5 \mathrm{ml}$ & $<2.5 \mathrm{ml}$ & $<<2.5 \mathrm{ml}$ & $<2.5 \mathrm{ml}$ & $<<2.5 \mathrm{ml}$ & $45 \mathrm{ml}$ \\
\hline$<2.5 \mathrm{ml}$ & - & - & - & $5 \mathrm{ml}$ & $<<2.5 \mathrm{ml}$ & $10 \mathrm{ml}$ & $<2.5 \mathrm{ml}$ & $<2.5 \mathrm{ml}$ & $<<2.5 \mathrm{ml}$ & - & $35 \mathrm{ml}$ \\
\hline$*$ & & & & & & & & & & & $*$ \\
\hline \multirow[t]{8}{*}{$4(0.06 g)$} & & & & $16(0.56 \mathrm{~g})$ & $1(0.05 \mathrm{~g})$ & $28(0.99 g)$ & $1(0.12 \mathrm{~g})$ & $2(0.05 \mathrm{~g})$ & $1(0.03 \mathrm{~g})$ & & $10(1.28 \mathrm{~g})$ \\
\hline & & & & & & & & & & & $8(0.93 \mathrm{~g})$ \\
\hline & & & & & & $5(0.10 \mathrm{~g})$ & & & & & $60(4.33 \mathrm{~g})$ \\
\hline & & & & $1(0.01 \mathrm{~g})$ & & $10(0.37 \mathrm{~g})$ & & $1(0.01 \mathrm{~g})$ & & & $3(0.42 \mathrm{~g})$ \\
\hline & & & & & & 7 & 1 & & & & \\
\hline & & & & & & 33 & 1 & & & & 86 \\
\hline & & & & & & & & & & & 106 \\
\hline & & & & & & 94 & 8 & & & & 399 \\
\hline $11(0.12 \mathrm{~g})$ & $1(<0.01 \mathrm{~g})$ & $2(0.02 \mathrm{~g})$ & $7(0.03 g)$ & & & & & & & $5(0.02 g)$ & \\
\hline
\end{tabular}




\section{APPENDIX 13: BOTANICAL RESULTS FROM LAIGH NEWTON EAST - RECTANGULAR STRUCTURE ASSOCIATED FEATURES}

\begin{tabular}{|c|c|c|c|c|}
\hline & Excavation code & 2028 & 2028 & 2028 \\
\hline & Context & 052 & 270 & 309 \\
\hline & Sample & 17 samples & $17,18,26,27,28, \mathrm{SF}$ & 89 \\
\hline & Description & Fill of groove 051 & Fill of pit 063 & Fill of pit 308 \\
\hline Modern & & +++ & - & ++ \\
\hline $\begin{array}{l}\text { Volume of charcoal } \\
>2 \mathrm{~mm}\end{array}$ & & $5 \mathrm{ml}$ & $700 \mathrm{ml}$ & $<2.5 \mathrm{ml}$ \\
\hline $\begin{array}{l}\text { Volume of charcoal } \\
>4 \mathrm{~mm}\end{array}$ & & $5 \mathrm{ml}$ & $10665 \mathrm{ml}$ & $2.5 \mathrm{ml}$ \\
\hline Extrapolated results & & $*$ & $*$ & \\
\hline \multicolumn{5}{|l|}{ Charcoal } \\
\hline Alnus & alder & & $354(382.8 \mathrm{~g})$ & \\
\hline Betula & birch & $24(0.58 \mathrm{~g})$ & 799 (2763.6g) & $1(0.04 \mathrm{~g})$ \\
\hline Corylus & hazel & $6(0.19 g)$ & & $3(0.11 \mathrm{~g})$ \\
\hline Quercus & oak & $1(0.02 \mathrm{~g})$ & & \\
\hline Salix & willow & $4(0.10 \mathrm{~g})$ & & \\
\hline Indet. small twigs & indeterminate small twigs & $1(0.01 \mathrm{~g})$ & & \\
\hline Indet. charcoal & indeterminate charcoal & $7(0.07 \mathrm{~g})$ & & \\
\hline Indet. bark & & & $49(54.17 \mathrm{~g})$ & \\
\hline \multicolumn{5}{|l|}{ Cereals (carb) } \\
\hline cf Avena sp. & cf oat & 2 & & \\
\hline \multicolumn{5}{|l|}{ Seeds etc (carb) } \\
\hline $\begin{array}{l}\text { Corylus avellana } \\
\text { nutshell frags }\end{array}$ & hazel nutshell frags & $1(0.04 \mathrm{~g})$ & & \\
\hline
\end{tabular}




\section{APPENDIX 14: BOTANICAL RESULTS FROM LAIGH NEWTON EAST - PIT CLUSTERS}

\begin{tabular}{|c|c|c|c|c|c|c|c|}
\hline & $\begin{array}{l}\text { Excavation } \\
\text { code }\end{array}$ & 2028 & 2028 & 2028 & 2028 & 2028 & 2028 \\
\hline & Context & 214 & 218 & 222 & 228 & 230 & 298 \\
\hline & Sample & 75 & 65 & 77 & 85,88 & 86 & SF77 \\
\hline & Description & $\begin{array}{l}\text { Fill of pit } \\
213\end{array}$ & $\begin{array}{l}\text { Fill of pit } \\
217\end{array}$ & $\begin{array}{l}\text { Fill of pit } \\
221\end{array}$ & $\begin{array}{l}\text { Fill of pit } \\
227\end{array}$ & $\begin{array}{l}\text { Fill of pit } \\
229\end{array}$ & $\begin{array}{l}\text { Fill of pit } \\
297\end{array}$ \\
\hline Modern & & + & +++ & +++ & ++ & +++ & - \\
\hline $\begin{array}{l}\text { Volume of } \\
\text { charcoal } \\
>2 \mathrm{~mm}\end{array}$ & & $40 \mathrm{ml}$ & $<2.5 \mathrm{ml}$ & $2.5 \mathrm{ml}$ & $100 \mathrm{ml}$ & $10 \mathrm{ml}$ & - \\
\hline $\begin{array}{l}\text { Volume of } \\
\text { charcoal } \\
>4 \mathrm{~mm}\end{array}$ & & $50 \mathrm{ml}$ & $2.5 \mathrm{ml}$ & $2.5 \mathrm{ml}$ & $70 \mathrm{ml}$ & $10 \mathrm{ml}$ & $<2.5 \mathrm{ml}$ \\
\hline $\begin{array}{l}\text { Extrapolated } \\
\text { results }\end{array}$ & & $*$ & & & $*$ & & \\
\hline \multicolumn{8}{|l|}{ Charcoal } \\
\hline Alnus & alder & & & & $4(0.68 g)$ & & \\
\hline Betula & birch & & $1(0.07 g)$ & $3(0.13 g)$ & & $2(0.42 \mathrm{~g})$ & \\
\hline Corylus & hazel & $60(9.70 \mathrm{~g})$ & $3(0.05 \mathrm{~g})$ & $3(0.13 \mathrm{~g})$ & $76(6.84 \mathrm{~g})$ & $12(0.42 \mathrm{~g})$ & \\
\hline Maloideae & rowan type & & & & & & \\
\hline Quercus & oak & & $2(0.03 g)$ & $5(0.22 \mathrm{~g})$ & $20(1.97 \mathrm{~g})$ & $12(0.55 \mathrm{~g})$ & \\
\hline Salix & willow & & & & $2(0.30 \mathrm{~g})$ & & \\
\hline $\begin{array}{l}\text { Indet. } \\
\text { charcoal }\end{array}$ & $\begin{array}{l}\text { indetermi- } \\
\text { nate charcoal }\end{array}$ & & $2(0.05 \mathrm{~g})$ & & & & \\
\hline \multicolumn{8}{|c|}{ Seeds etc (carb) } \\
\hline $\begin{array}{l}\text { Corylus } \\
\text { avellana } \\
\text { nutshell frags }\end{array}$ & $\begin{array}{l}\text { hazel nutshell } \\
\text { frags }\end{array}$ & 47 (0.93g) & $4(0.06 g)$ & $12(0.17 \mathrm{~g})$ & & $2(0.04 \mathrm{~g})$ & $4(0.15 g)$ \\
\hline Rhizome & rhizome & 1 & & & & & \\
\hline
\end{tabular}




\begin{tabular}{|c|c|c|c|c|c|c|c|}
\hline & $\begin{array}{l}\text { Excavation } \\
\text { code }\end{array}$ & 1259 & 2028 & 1259 & 2028 & 1259 & 2028 \\
\hline & Context & 11004 & 296 & 11005 & 294 & 11008 & 293/295 \\
\hline & Sample & 2, SF3 & $72,74,81$ & 3, SF7 & $70,71,73,80$ & 4 & SF105 \\
\hline & Description & $\begin{array}{l}\text { Fill of pit } \\
297\end{array}$ & $\begin{array}{l}\text { Fill of pit } \\
295\end{array}$ & $\begin{array}{l}\text { Fill of pit } \\
295\end{array}$ & $\begin{array}{l}\text { Fill of pit } \\
293\end{array}$ & $\begin{array}{l}\text { Fill of pit } \\
293\end{array}$ & $\begin{array}{l}\text { Interface of } \\
\text { pits } 293 \& \\
295\end{array}$ \\
\hline Modern & & + & - & + & - & + & - \\
\hline $\begin{array}{l}\text { Volume of } \\
\text { charcoal } \\
>2 \mathrm{~mm}\end{array}$ & & $140 \mathrm{ml}$ & $45 \mathrm{ml}$ & $50 \mathrm{ml}$ & $30 \mathrm{ml}$ & $50 \mathrm{ml}$ & - \\
\hline $\begin{array}{l}\text { Volume of } \\
\text { charcoal } \\
>4 \mathrm{~mm}\end{array}$ & & $220 \mathrm{ml}$ & $65 \mathrm{ml}$ & $260 \mathrm{ml}$ & $75 \mathrm{ml}$ & $60 \mathrm{ml}$ & $5 \mathrm{ml}$ \\
\hline $\begin{array}{l}\text { Extrapolated } \\
\text { results }\end{array}$ & & $*$ & $*$ & $*$ & $*$ & $*$ & \\
\hline \multicolumn{8}{|l|}{ Charcoal } \\
\hline Alnus & alder & & & & & $5(0.92 \mathrm{~g})$ & \\
\hline Betula & birch & & & & & & \\
\hline Corylus & hazel & $242(32.4 \mathrm{~g})$ & $101(15.51 \mathrm{~g})$ & 267 (51.53g) & $103(17.2 \mathrm{~g})$ & $90(10.52 \mathrm{~g})$ & \\
\hline Maloideae & rowan type & $4(0.64 g)$ & & & & $2(0.30 \mathrm{~g})$ & \\
\hline Quercus & oak & $8(0.76 g)$ & & & $2(0.24 \mathrm{~g})$ & & \\
\hline Salix & willow & $8(0.88 g)$ & $1(0.10 \mathrm{~g})$ & & & $2(0.20 \mathrm{~g})$ & \\
\hline $\begin{array}{l}\text { Indet. } \\
\text { charcoal }\end{array}$ & $\begin{array}{l}\text { indetermi- } \\
\text { nate charcoal }\end{array}$ & & & & & & \\
\hline \multicolumn{8}{|c|}{ Seeds etc (carb) } \\
\hline $\begin{array}{l}\text { Corylus } \\
\text { avellana } \\
\text { nutshell frags }\end{array}$ & $\begin{array}{l}\text { hazel nutshell } \\
\text { frags }\end{array}$ & 623 (19.23g) & $114(2.83 \mathrm{~g})$ & 290 (7.81g) & $168(3.59 \mathrm{~g})$ & $100(2.18 \mathrm{~g})$ & $11(0.41 \mathrm{~g})$ \\
\hline Rhizome & rhizome & & & & & & \\
\hline
\end{tabular}




\section{APPENDIX 15: BOTANICAL RESULTS FROM LAIGH NEWTON EAST - MISCELLANEOUS PITS AND POSTHOLES}

\begin{tabular}{|c|c|c|c|c|c|c|c|c|c|c|}
\hline & $\begin{array}{l}\text { Excavation } \\
\text { code }\end{array}$ & 2028 & 2028 & 2028 & 2028 & 2028 & 2028 & 2028 & 2028 & 2028 \\
\hline & Context & 002 & 018 & 026 & 030 & 034 & 118 & 120 & 140 & 144 \\
\hline & Sample & 1 & 4 & 23 & 16 & 39 & 14 & 12 & 54 & 10 \\
\hline & Description & 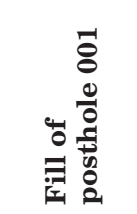 & 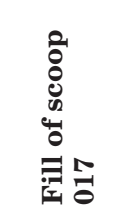 & 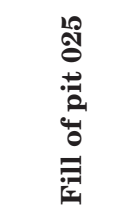 & 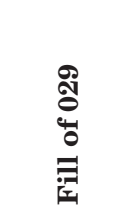 & 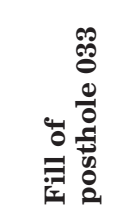 & 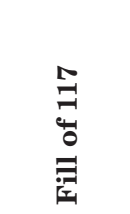 & 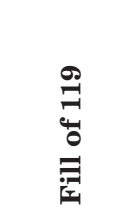 & 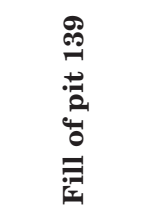 & 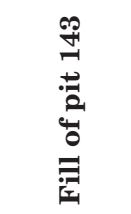 \\
\hline Modern & & + & + & + & + & + & + & + & + & + \\
\hline $\begin{array}{l}\text { Volume of } \\
\text { charcoal }>2 \mathrm{~mm}\end{array}$ & & $15 \mathrm{ml}$ & $5 \mathrm{ml}$ & $<<2.5 \mathrm{ml}$ & $10 \mathrm{ml}$ & $15 \mathrm{ml}$ & $<<2.5 \mathrm{ml}$ & $<2.5 \mathrm{ml}$ & $10 \mathrm{ml}$ & $5 \mathrm{ml}$ \\
\hline $\begin{array}{l}\text { Volume of } \\
\text { charcoal }>4 \mathrm{~mm}\end{array}$ & & $15 \mathrm{ml}$ & $5 \mathrm{ml}$ & - & $5 \mathrm{ml}$ & $10 \mathrm{ml}$ & $<<2.5 \mathrm{ml}$ & - & $10 \mathrm{ml}$ & $5 \mathrm{ml}$ \\
\hline $\begin{array}{l}\text { Extrapolated } \\
\text { results }\end{array}$ & & & & & & & & & $*$ & \\
\hline \multicolumn{11}{|l|}{ Charcoal } \\
\hline Alnus & alder & $\begin{array}{l}26 \\
(1.94 \mathrm{~g})\end{array}$ & & & $9(0.49 g)$ & $\begin{array}{l}14 \\
(0.55 \mathrm{~g})\end{array}$ & & & $8(0.74 \mathrm{~g})$ & $3(0.19 g)$ \\
\hline Betula & birch & $7(0.23 \mathrm{~g})$ & & & $1(0.06 \mathrm{~g})$ & $\begin{array}{l}10 \\
(0.49 g)\end{array}$ & & & & \\
\hline Corylus & hazel & $8(0.30 \mathrm{~g})$ & $8(0.28 \mathrm{~g})$ & & & $2(0.12 \mathrm{~g})$ & & & $\begin{array}{l}14 \\
(0.48 g)\end{array}$ & $1(0.08 \mathrm{~g})$ \\
\hline Quercus & oak & $2(0.08 g)$ & $1(0.05 \mathrm{~g})$ & & & $2(0.37 \mathrm{~g})$ & & & & $3(0.41 \mathrm{~g})$ \\
\hline Salix & willow & & & & & & $1(0.02 \mathrm{~g})$ & & & \\
\hline \multicolumn{11}{|l|}{ Cereals (carb) } \\
\hline $\begin{array}{l}\text { Hordeum } \\
\text { vulgare var } \\
\text { vulgare }\end{array}$ & $\begin{array}{l}\text { hulled six- } \\
\text { row barley }\end{array}$ & & & & 12 & & & & & \\
\hline $\begin{array}{l}\text { Hordeum } \\
\text { vulgare sl. }\end{array}$ & $\begin{array}{l}\text { six-row } \\
\text { barley }\end{array}$ & & & & 18 & & & & & \\
\hline $\begin{array}{l}\text { cf Hordeum } \\
\text { vulgare sl. }\end{array}$ & $\begin{array}{l}\text { cf six-row } \\
\text { barley }\end{array}$ & & & & 15 & & & & & \\
\hline Triticum sp. & cf wheat & & & & & & & & & \\
\hline Cereal indet. & $\begin{array}{l}\text { cereal inde- } \\
\text { terminate }\end{array}$ & & & & 27 & & & & & \\
\hline \multicolumn{11}{|l|}{ Seeds etc (carb) } \\
\hline $\begin{array}{l}\text { Corylus avellana } \\
\text { nutshell frags }\end{array}$ & $\begin{array}{l}\text { hazel } \\
\text { nutshell } \\
\text { frags }\end{array}$ & $1(0.02 \mathrm{~g})$ & & $1(0.02 \mathrm{~g})$ & & $3(0.02 \mathrm{~g})$ & & $\begin{array}{l}10 \\
(0.06 \mathrm{~g})\end{array}$ & $1(0.01 \mathrm{~g})$ & $2(0.01 \mathrm{~g})$ \\
\hline Rhizome & rhizome & & & & & & & & & \\
\hline
\end{tabular}




\begin{tabular}{|c|c|c|c|c|c|c|c|c|c|}
\hline & $\begin{array}{l}\text { Excavation } \\
\text { code }\end{array}$ & 2028 & 2028 & 2028 & 2028 & 2028 & 2028 & 2028 & 2028 \\
\hline & Context & 212 & 276 & 286 & 290 & 292 & 302 & 304 & 306 \\
\hline & Sample & $\begin{array}{l}\text { 79, SF83, } \\
\text { 2xSF }\end{array}$ & 20 & 55 & 59 & 60 & 64 & 66 & 76 \\
\hline & Description & 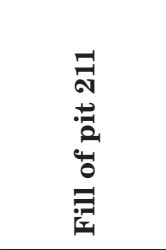 & 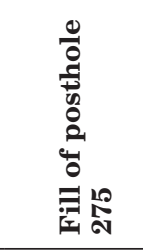 & 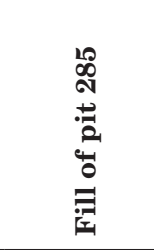 & 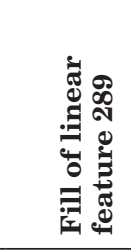 & 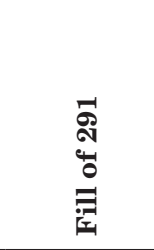 & 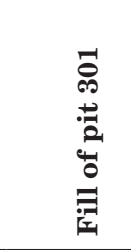 & 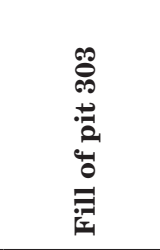 & 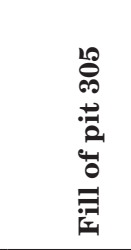 \\
\hline Modern & & + & + & + & + & + & + & + & + \\
\hline $\begin{array}{l}\text { Volume of } \\
\text { charcoal }>2 \mathrm{~mm}\end{array}$ & & $140 \mathrm{ml}$ & $2.5 \mathrm{ml}$ & $2.5 \mathrm{ml}$ & $<2.5 \mathrm{ml}$ & $10 \mathrm{ml}$ & - & $60 \mathrm{ml}$ & $<<2.5 \mathrm{ml}$ \\
\hline $\begin{array}{l}\text { Volume of } \\
\text { charcoal }>4 \mathrm{~mm}\end{array}$ & & $120 \mathrm{ml}$ & $2.5 \mathrm{ml}$ & $22.5 \mathrm{ml}$ & $<2.5 \mathrm{ml}$ & $15 \mathrm{ml}$ & - & $80 \mathrm{ml}$ & - \\
\hline $\begin{array}{l}\text { Extrapolated } \\
\text { results }\end{array}$ & & $*$ & & $*$ & & * & & $*$ & \\
\hline \multicolumn{10}{|l|}{ Charcoal } \\
\hline Alnus & alder & & $2(0.01 \mathrm{~g})$ & & & $16(0.82 \mathrm{~g})$ & & $50(5.40 \mathrm{~g})$ & \\
\hline Betula & birch & $16(5.8 \mathrm{~g})$ & & $3(0.09 g)$ & & $2(0.04 \mathrm{~g})$ & & & \\
\hline Corylus & hazel & $85(15.01 \mathrm{~g})$ & & $18(0.96 \mathrm{~g})$ & $1(0.06 \mathrm{~g})$ & 27 (1.53g) & & $75(12.00 \mathrm{~g})$ & \\
\hline Quercus & oak & $86(14.65 \mathrm{~g})$ & $2(0.02 \mathrm{~g})$ & 27 (1.44g) & & $3(0.08 \mathrm{~g})$ & & $18(1.15 \mathrm{~g})$ & \\
\hline Salix & willow & $12(2.12 \mathrm{~g})$ & $1(0.01 \mathrm{~g})$ & & $2(0.02 \mathrm{~g})$ & & & & \\
\hline \multicolumn{10}{|l|}{ Cereals (carb) } \\
\hline $\begin{array}{l}\text { Hordeum vulgare } \\
\text { var vulgare }\end{array}$ & $\begin{array}{l}\text { hulled six-row } \\
\text { barley }\end{array}$ & & & & & & & & \\
\hline $\begin{array}{l}\text { Hordeum vulgare } \\
\text { sl. }\end{array}$ & six-row barley & & & & & & & & \\
\hline $\begin{array}{l}\text { cf Hordeum } \\
\text { vulgare sl. }\end{array}$ & $\begin{array}{l}\text { cf six-row } \\
\text { barley }\end{array}$ & & & & & & & & \\
\hline Triticum sp. & cf wheat & 1 & & & & & & & \\
\hline Cereal indet. & $\begin{array}{l}\text { cereal } \\
\text { indeterminate }\end{array}$ & & & & & & & & \\
\hline \multicolumn{10}{|l|}{ Seeds etc (carb) } \\
\hline $\begin{array}{l}\text { Corylus avellana } \\
\text { nutshell frags }\end{array}$ & $\begin{array}{l}\text { hazel nutshell } \\
\text { frags }\end{array}$ & $\begin{array}{l}664 \\
(19.16 g)\end{array}$ & $3(0.02 \mathrm{~g})$ & & & & $1(0.02 \mathrm{~g})$ & $16(0.31 \mathrm{~g})$ & $4(0.01 \mathrm{~g})$ \\
\hline Rhizome & rhizome & & $1(0.21 \mathrm{~g})$ & & & & & & \\
\hline
\end{tabular}




\section{APPENDIX 16: BOTANICAL RESULTS FROM LAIGH NEWTON EAST - ADDITIONAL PREHISTORIC FEATURES}

\begin{tabular}{|c|c|c|c|}
\hline & Excavation code & 2028 & 2028 \\
\hline & Context & 39005 & 39007 \\
\hline & Sample & 2 & 3 \\
\hline & Description & Fill of pit 39006 & Fill of pit 39008 \\
\hline Modern & & +++ & +++ \\
\hline Volume of charcoal $>2 \mathrm{~mm}$ & & $40 \mathrm{ml}$ & $80 \mathrm{ml}$ \\
\hline Volume of charcoal $>4 \mathrm{~mm}$ & & $60 \mathrm{ml}$ & $40 \mathrm{ml}$ \\
\hline Extrapolated results & & $*$ & $*$ \\
\hline \multicolumn{4}{|l|}{ Charcoal } \\
\hline Betula & birch & $15(0.84 \mathrm{~g})$ & $6(0.52 g)$ \\
\hline Corylus & hazel & $52(4.20 \mathrm{~g})$ & $72(4.80 \mathrm{~g})$ \\
\hline Quercus & oak & $96(12.75 \mathrm{~g})$ & $75(4.23 \mathrm{~g})$ \\
\hline \multicolumn{4}{|l|}{ Cereals (carb) } \\
\hline Triticum dicoccum & emmer wheat & 133 & 104 \\
\hline $\begin{array}{l}\text { Triticum dicoccum spikelet } \\
\text { base }\end{array}$ & emmer sp.ikelet base (chaff) & 38 & \\
\hline $\begin{array}{l}\text { Triticum dicoccum glume } \\
\text { base }\end{array}$ & emmer glume base (chaff) & 54 & \\
\hline Tritcum cf aestivum & cf bread wheat & 4 & 6 \\
\hline Triticum sp. & wheat & 119 & 42 \\
\hline Cereal indet. & cereal indeterminate & 143 & 96 \\
\hline Cereal indet. chaff frags & & 41 & \\
\hline \multicolumn{4}{|l|}{ Seeds etc (carb) } \\
\hline $\begin{array}{l}\text { Corylus avellana nutshell } \\
\text { frags }\end{array}$ & hazel nutshell frags & $307(11.50 \mathrm{~g})$ & \\
\hline Plantago lanceolata & ribwort plantain & 1 & \\
\hline cf Rosa & cf rose & 1 & \\
\hline Rumex sp. & dock & 1 & \\
\hline Sorbus aucuparia & rowan & & 1 \\
\hline Spergula arvensis & corn spurrey & 1 & \\
\hline
\end{tabular}

